\title{
Bidens pilosa L. (Asteraceae): Botanical Properties, Traditional Uses, Phytochemistry, and Pharmacology
}

\author{
Arlene P. Bartolome, ${ }^{1,2}$ Irene M. Villaseñor, ${ }^{1}$ and Wen-Chin Yang ${ }^{2,3,4,5,6}$ \\ ${ }^{1}$ Institute of Chemistry, University of the Philippines, Diliman, Quezon City 1101, Philippines \\ ${ }^{2}$ Agricultural Biotechnology Research Center, Academia Sinica, Taipei 115, Taiwan \\ ${ }^{3}$ Institute of Pharmacology, Yang-Ming University, Taipei 112, Taiwan \\ ${ }^{4}$ Department of Life Sciences, National Chung-Hsing University, Taichung 402, Taiwan \\ ${ }^{5}$ Institute of Zoology, National Taiwan University, Taipei 106, Taiwan \\ ${ }^{6}$ Department of Aquaculture, National Taiwan Ocean University, Keelung 20224, Taiwan
}

Correspondence should be addressed to Wen-Chin Yang; wcyang@gate.sinica.edu.tw

Received 31 January 2013; Accepted 29 April 2013

Academic Editor: Gail B. Mahady

Copyright ( $) 2013$ Arlene P. Bartolome et al. This is an open access article distributed under the Creative Commons Attribution License, which permits unrestricted use, distribution, and reproduction in any medium, provided the original work is properly cited.

\begin{abstract}
There are 230 to 240 known Bidens species. Among them, Bidens pilosa is a representative perennial herb, globally distributed across temperate and tropical regions. $B$. pilosa has been traditionally used in foods and medicines without obvious adverse effects. Despite significant progress in phytochemical and biological analyses of $B$. pilosa over the past few years, comprehensive and critical reviews of this plant are anachronistic or relatively limited in scope. The present review aims to summarize up-to-date information on the phytochemistry, pharmacology, and toxicology of B. pilosa from the literature. In addition to botanical studies and records of the traditional use of $B$. pilos $a$ in over 40 diseases, scientific studies investigating the potential medicinal uses of this species and its constituent phytochemicals for a variety of disorders are presented and discussed. The structure, bioactivity, and likely mechanisms of action of $B$. pilosa and its phytochemicals are emphasized. Although some progress has been made, further rigorous efforts are required to investigate the individual compounds isolated from $B$. pilosa to understand and validate its traditional uses and develop clinical applications. The present review provides preliminary information and gives guidance for further basic and clinical research into this plant.
\end{abstract}

\section{Introduction}

The United Nations World Health Organization estimates that as many as 5.6 billion people, $80 \%$ of the world population, utilize herbal medicine for primary health care [1]. Plants have formed the foundation of complicated traditional medicine systems for thousands of years. Medicinal herbs are applied to treat a wide range of disease categories. The first written documentation of the use of medicinal herbs dates from the 26th century BCE in Mesopotamia, and the first record of the use of medicinal herbs by the Egyptians and Greeks dates from 18th century BCE and the 5th century $\mathrm{BCE}$, respectively. Starting around the 11th century BCE, the Chinese and Indians started to develop herbal medicine systems, Chinese herbal medicine, and Ayurvedic medicine, respectively, that continue to be widely practiced today [2]. Therefore, since antiquity, medicinal herbs have played a prominent role in human health.

$B$. pilosa is an easy-to-grow herb that is widely distributed all over the world. It is considered to be a rich source of food and medicine for humans and animals [3, 4]. There is increasing global interest in the use of $B$. pilosa as shown by the many studies conducted on the plant in recent years. The folkloric use of B. pilosa has been recorded in America, Africa, Asia, and Oceania [5]. To explore the potential clinical application of $B$. pilosa, it is important to link its traditional use with rigorous evidence-based scientific study. The present review focuses on recent studies on the botany, traditional usage, phytochemistry, pharmacology, and toxicology of $B$. pilosa. The information provided here highlights the possible 
Table 1: Taxonomy of B. pilosa [6].

\begin{tabular}{lc}
\hline Kingdom & Plantae \\
Subkingdom & Tracheobionta \\
Superdivision & Spermatophyta \\
Division & Magnoliophyta \\
Class & Magnoliopsida \\
Subclass & Asteridae \\
Order & Asterales \\
Family & Asteraceae \\
Genus & Bidens \\
Species & Bidens Pilosa L. \\
\hline
\end{tabular}

usefulness of $B$. pilosa and its isolated compounds and offers insights into possible future research directions. Studies of $B$. pilosa are divided into three groups: (1) the botany, ethnomedical uses, plant chemistry, pharmacology, and biosafety of $B$. pilosa; (2) scientific studies that validate the ethnomedical uses of $B$. pilosa; and (3) the therapeutic and future research potential of $B$. pilosa.

1.1. Botany. B. pilosa was first collected and named by Carl Linnaeus in 1753 [3]. Taxonomically, it is assigned to the Bidens genus (Asteraceae) as shown in Table 1. This genus is estimated to include 230 to 240 species worldwide $[3,4]$. B. pilosa has several varieties such as $B$. pilosa var. radiata, var. minor, var. pilosa, and var. bisetosa. Alongside examination of morphological traits, authentication of B. pilosa can be aided by chemotaxonomy and molecular characterization [7].

B. pilosa is an erect, perennial herb widely distributed across temperate and tropical regions. B. pilosa is either glabrous or hairy, with green opposite leaves that are serrate, lobed, or dissected. It has white or yellow flowers, and long narrow ribbed black achenes (seeds). It grows to an average height of $60 \mathrm{~cm}$ and a maximum of $150 \mathrm{~cm}$ in favorable environments [8] (Figure 1). B. pilosa prefers full sun and moderately dry soil. However, it can grow in arid and barren land from low to high elevations. With the advantage of being fast-growing, in the 1970s, the Food and Agricultural Organization actively promoted the cultivation of $B$. pilosa in Africa [9]. B. pilosa propagates via seeds. A single plant can produce 3000-6000 seeds. Dry mature seeds from $B$. pilosa can be germinated in 3 to 4 days in moist soil or after being soaking in water. Seeds are viable for at least 3 years [10]. Minimal agricultural techniques are required for $B$. pilosa cultivation. Due to its invasive tendencies, B. pilosa is generally considered to be a weed [11].

B. pilosa is thought to have originated in South America and subsequently spread all over the world [12]. Bidens species and their varieties bear vernacular names based on their characteristics. For example, Bidens species are known by such names as Spanish needles, beggar's ticks, devil's needles, cobbler's pegs, broom stick, pitchforks, and farmers' friends in English and some other languages because of their sticky achenes [8] and are sometimes known as xian feng cao ("all bountiful grass") in Chinese because of their prosperous growth.
1.2. Traditional Uses. B. pilosa is used as an herb and as an ingredient in teas or herbal medicines. Its shoots and leaves, dried or fresh, are utilized in sauces and teas [13, 14]. In the 1970s, the United Nations Food and Agriculture Organization (FAO) promoted the cultivation of $B$. pilosa in Africa because it is easy to grow, edible, palatable, and safe [15]. The nutritional value of $B$. pilosa is shown in Table 2.

All parts of $B$. pilosa plant, the whole plant, the aerial parts (leaves, flowers, seeds, and stems), and/or the roots, fresh or dried, are used as ingredients in folk medicines. It is frequently prepared as a dry powder, decoction, maceration or tincture [16]. Generally, this plant is applied as dry powder or tincture when used externally, and as a powder, maceration, or decoction when used as an internal remedy [14].

As summarized in Table 3, B. pilosa, either as a whole plant or different parts, has been reported to be useful in the treatment of more than 40 disorders such as inflammation, immunological disorders, digestive disorders, infectious diseases, cancers, metabolic syndrome, wounds, and many others [17-20]. B. pilosa is usually ingested; however, it can also be utilized externally. For instance, fresh B. pilosa is used to treat snake bites and wounds [21], and in Trinidad and Tobago the aqueous solution of the leaves of $B$. pilosa is used to bathe babies and children [22].

B. pilosa is sometimes used alone; it is also used as an ingredient in medicinal mixtures together with other medicinal plants such as Aloe vera, Plectranthus mollis, Valeriana officinalis, and Cissus sicyoides among others [2326]. Whether the commonly used mixtures of B. pilosa, or the mixtures of the compounds found in B. pilosa afford synergistic effects is not yet clear and needs to be verified by further studies. However, one study has suggested that B. pilosa varieties share similar phytochemical compositions and may be substituted for each other [7].

\section{Phytochemicals}

Interest in basic research and application of B. pilosa has increased since its first identification in 1753. This is mainly due to its wide application in medicines, foods, and drinks. Around 116 publications have documented the exploitation and medical use of $B$. pilosa. To date, 201 compounds comprising 70 aliphatics, 60 flavonoids, 25 terpenoids, 19 phenylpropanoids, 13 aromatics, 8 porphyrins, and 6 other compounds, have been identified from this plant as compiled previously [27]. The structures of these compounds are presented in Tables 4, 5, 6, 7, 8, 9, and 10, respectively. However, the association between $B$. pilosa phytochemicals and their bioactivities is not yet fully established and should become a future research focus. In the present review, we explore possible associations (Table 11), describe the importance of the known compounds in relation to their biological activity and discuss their likely mechanisms of action (Table 3). Compelling evidence suggests that the various diverse bioactivities reported for $B$. pilosa reflect its phytochemical complexity.

B. pilosa is an extraordinary source of phytochemicals, particularly flavonoids and polyynes. Plant flavonoids are 
TAble 2: Nutritional facts about B. pilosa, courtesy of the United Nations Food and Agriculture Organization [15].

\begin{tabular}{lccccccccccc}
\hline $\begin{array}{l}\text { Plant } \\
(100 \mathrm{~g})\end{array}$ & $\begin{array}{c}\text { Energy } \\
(\mathrm{kcal})\end{array}$ & $\begin{array}{c}\text { Moisture } \\
(\%)\end{array}$ & $\begin{array}{c}\text { Protein } \\
(\mathrm{g})\end{array}$ & $\begin{array}{c}\text { Fat } \\
(\mathrm{g})\end{array}$ & $\begin{array}{c}\text { Carbohydrate } \\
(\mathrm{g})\end{array}$ & $\begin{array}{c}\text { Fiber } \\
(\mathrm{g})\end{array}$ & $\begin{array}{c}\text { Ash } \\
(\mathrm{g})\end{array}$ & $\begin{array}{c}\text { Calcium } \\
(\mathrm{mg})\end{array}$ & $\begin{array}{c}\text { Phosphorus } \\
(\mathrm{mg})\end{array}$ & $\begin{array}{c}\text { Iron } \\
(\mu \mathrm{g})\end{array}$ & $\begin{array}{c}\text { Carotene } \\
\text { equivalent } \\
(\mu \mathrm{g})\end{array}$ \\
\hline Raw & 43 & 85.1 & 3.8 & 0.5 & 8.4 & 3.9 & 2.2 & 340 & 67 & - & 1800 \\
Dried & 33 & 88.6 & 2.8 & 0.6 & 6 & 1.3 & 2 & 111 & 39 & 2.3 & - \\
\hline
\end{tabular}

"-" denotes not detectable.

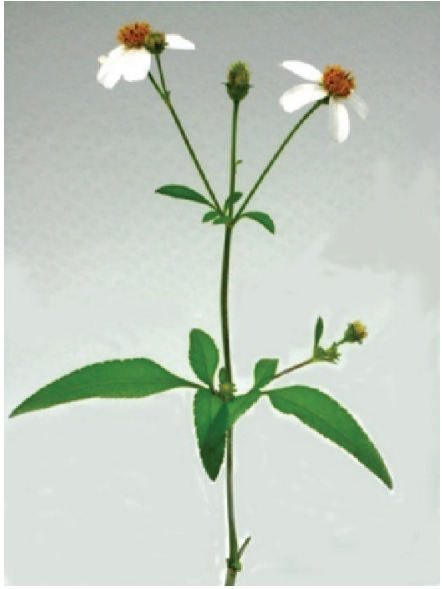

(a)

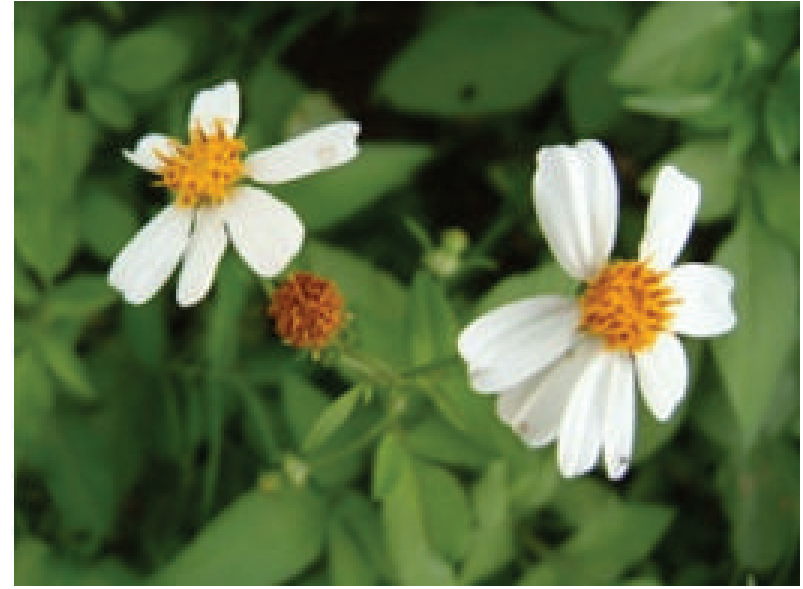

(b)

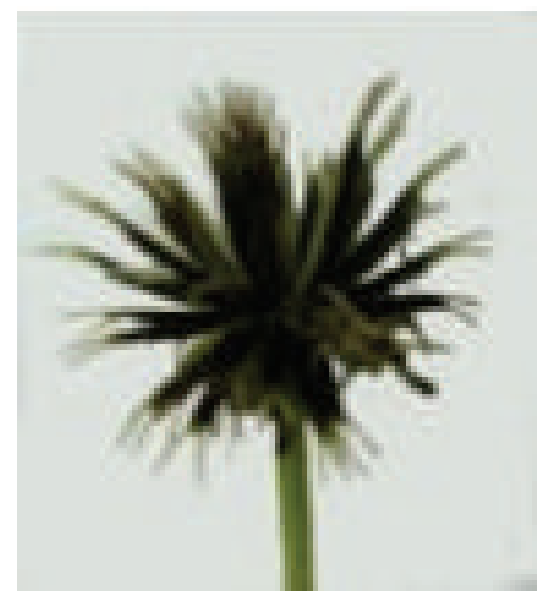

(c)

Figure 1: B. pilosa (a) and its flowers (b) and achenes (c).

commonly reported to possess anticancer, antiinflammatory, antioxidant, and other bioactivities. However, the bioactivities of only seven of the 60 flavonoids present in B. pilosa have been studied. The bioactivities of the remaining 53 flavonoids are poorly understood and deserve further investigation. Other classes of compounds found in B. pilosa are also in need of further examination, as shown in Table 11.

\section{Pharmacological Properties}

As outlined in Table 3, B. pilosa is traditionally used to treat a wide variety of ailments. Different preparations of its whole plant and/or parts have been purported to treat over 40 categories of illnesses. Scientific studies, although not extensive, have demonstrated that $B$. pilosa extracts and/or compounds have antitumor [28-36], antiinflammatory [18, 32, 37-42], antidiabetic and antihyperglycemic [7, 43-46], antioxidant [47-49], immunomodulatory [29, 50], antimalarial [30, 51], antibacterial [51-53], antifungal [53, 54], antihypertensive, vasodilatory $[19,55]$, and antiulcerative [17] activities. In this section, the primary pharmacological properties of $B$. pilosa extracts and phytochemicals are presented and discussed.

3.1. Anticancer Activity. Folkloric reports revealed the possible antitumor efficacy of B. pilosa, and several scientific 
TABLE 3: Ethnomedical information about B. pilosa.

\begin{tabular}{|c|c|c|c|c|}
\hline Disorder & Plant part ${ }^{\mathrm{b}}$ & Mode of use & Region/Country & References \\
\hline Stomachache & $\mathrm{LE}$ & Decoction & $\begin{array}{l}\text { India } \\
\text { Africa }\end{array}$ & {$[23,25,56]$} \\
\hline Colics & WP & Decoction & $\begin{array}{l}\text { Africa } \\
\text { China }\end{array}$ & {$[25]$} \\
\hline Catarrh & WP & $\begin{array}{l}\text { Juice or decoction; taken } \\
\text { orally }\end{array}$ & Cuba & {$[24]$} \\
\hline Diarrhea & LE and WP & Fresh leaves or Decoction & $\begin{array}{l}\text { Africa } \\
\text { Uganda }\end{array}$ & {$[25,57]$} \\
\hline Constipation & WP & Decoction & Africa & {$[25]$} \\
\hline $\begin{array}{l}\text { Dysentery/Bacillary } \\
\text { dysentery }\end{array}$ & WP & Decoction & $\begin{array}{l}\text { Africa } \\
\text { China }\end{array}$ & {$[25]$} \\
\hline Choleretic & $\mathrm{WP}$ & Decoction & Middle America & {$[25]$} \\
\hline Anti-inflammatory & WP & Not stated & $\begin{array}{l}\text { China } \\
\text { Cuba }\end{array}$ & {$[22,24]$} \\
\hline Asthma & WP & $\begin{array}{l}\text { Decoction or maceration; } \\
\text { taken orally }\end{array}$ & $\begin{array}{l}\text { Cuba } \\
\text { China }\end{array}$ & {$[21,24]$} \\
\hline Antirheumatic & $\mathrm{RT}$ and $\mathrm{WP}$ & Juice and decoction & $\begin{array}{l}\text { Hong Kong } \\
\text { Zulu, Africa }\end{array}$ & {$[22,25]$} \\
\hline Acute appendicitis & WP & Decoction & Hong Kong & {$[21]$} \\
\hline Enteritis & WP & Decoction & $\begin{array}{l}\text { Africa } \\
\text { China }\end{array}$ & {$[25]$} \\
\hline Pruritus & WP & Decoction & Hong Kong & {$[21]$} \\
\hline Conjunctivitis & WP & Decoction & $\begin{array}{l}\text { Africa } \\
\text { China }\end{array}$ & {$[25]$} \\
\hline Otitis & WP & Decoction & $\begin{array}{l}\text { Africa } \\
\text { China }\end{array}$ & {$[25]$} \\
\hline Pharyngitis & WP & Decoction & $\begin{array}{l}\text { Africa } \\
\text { China }\end{array}$ & {$[25]$} \\
\hline Gastritis & WP & Juice; taken orally & Cuba & {$[24]$} \\
\hline Diabetes & WP & Decoction; taken orally & $\begin{array}{l}\text { Cuba } \\
\text { Taiwan }\end{array}$ & {$[24,43]$} \\
\hline Headache & WP & Decoction & Bafia, Cameroon & {$[26]$} \\
\hline Diuretic & WP & Decoction & Middle America & {$[25]$} \\
\hline Hypotensive & WP & Decoction; taken orally & Bafia, Cameroon & {$[26]$} \\
\hline Colds & LE and WP & Fresh or decoction & $\begin{array}{l}\text { China } \\
\text { Middle America } \\
\text { Uganda }\end{array}$ & {$[21,25,57]$} \\
\hline Yellow Fever & LE and WP & Fresh or decoction & $\begin{array}{l}\text { China } \\
\text { Middle America } \\
\text { Uganda }\end{array}$ & {$[21,22,25,57]$} \\
\hline Influenza & LE and WP & Fresh or decoction & $\begin{array}{l}\text { China } \\
\text { Middle America } \\
\text { Uganda }\end{array}$ & {$[21,25,57]$} \\
\hline $\begin{array}{l}\text { Acute infectious } \\
\text { hepatitis }\end{array}$ & WP & Decoction & Hong Kong & {$[21]$} \\
\hline Intestinal worms & WP & Decoction & Africa & {$[25]$} \\
\hline Malaria & RT and WP & Juice & $\begin{array}{l}\text { Africa } \\
\text { China }\end{array}$ & {$[21,25]$} \\
\hline Eye Infection & LE and WP & Fresh or juice & $\begin{array}{l}\text { Uganda } \\
\text { Middle America }\end{array}$ & {$[25,57]$} \\
\hline
\end{tabular}


TABLe 3: Continued.

\begin{tabular}{|c|c|c|c|c|}
\hline Disorder & Plant part $^{\mathrm{b}}$ & Mode of use & Region/Country & References \\
\hline Antimicrobial & $\mathrm{AP}$ & $\begin{array}{l}\text { Decoction for drinking; } \\
\text { bathing/external use }\end{array}$ & $\begin{array}{l}\text { Trinidad and } \\
\text { Tobago }\end{array}$ & {$[22]$} \\
\hline $\begin{array}{l}\text { Pulmonary } \\
\text { tuberculosis }\end{array}$ & WP & $\begin{array}{l}\text { Decoction or maceration; } \\
\text { taken orally }\end{array}$ & $\begin{array}{l}\text { Cuba } \\
\text { China }\end{array}$ & {$[21,24]$} \\
\hline $\begin{array}{l}\text { Bacterial infections } \\
\text { in } \\
\text { gastrointestinal tracts }\end{array}$ & WP & Decoction & $\begin{array}{l}\text { Trinidad and } \\
\text { Tobago }\end{array}$ & {$[22]$} \\
\hline Renal infection & LE & Decoction; taken orally & Cuba & {$[24]$} \\
\hline Sore throat & LE and WP & Fresh or decoction & $\begin{array}{l}\text { China } \\
\text { Middle America } \\
\text { Uganda }\end{array}$ & {$[21,25,57]$} \\
\hline Cough & WP & Decoction; taken orally & $\begin{array}{l}\text { Cuba } \\
\text { China }\end{array}$ & {$[21,24]$} \\
\hline $\begin{array}{l}\text { Coolness of the } \\
\text { uterus }\end{array}$ & WP & Decoction; taken orally & Cuba & {$[24]$} \\
\hline $\begin{array}{l}\text { Menstrual } \\
\text { irregularities }\end{array}$ & WP & Decoction; taken orally & Cuba & {$[24]$} \\
\hline Dysmenorrhea & WP & Decoction & Bafia, Cameroon & {$[26]$} \\
\hline $\begin{array}{l}\text { Hyperemesis } \\
\text { gravidarum } \\
\text { (morning sickness) }\end{array}$ & WP & Decoction & Africa & {$[25]$} \\
\hline Hemorrhoids & WP & Decoction & Hong Kong & [21] \\
\hline Nose bleeds & LE and WP & Fresh or decoction & $\begin{array}{l}\text { China } \\
\text { Middle America } \\
\text { Uganda }\end{array}$ & {$[21,25,57]$} \\
\hline Stomach ulcers & $\mathrm{LE}$ and WP & $\begin{array}{l}\text { Maceration or juice; taken } \\
\text { orally }\end{array}$ & $\begin{array}{l}\text { Cuba } \\
\text { Middle America } \\
\text { Uganda }\end{array}$ & {$[21,24,25,57]$} \\
\hline $\begin{array}{l}\text { Cuts, burns, and skin } \\
\text { problems }\end{array}$ & $\mathrm{LE}$ and WP & $\begin{array}{l}\text { Fresh plant or decoction; } \\
\text { topical } \\
\text { application/bathing }\end{array}$ & $\begin{array}{l}\text { Trinidad and } \\
\text { Tobago } \\
\text { Africa } \\
\text { China } \\
\text { Cameroon } \\
\text { Brazil } \\
\text { Venezuela }\end{array}$ & {$[17,22,25]$} \\
\hline Wounds & WP & Crushed herb & $\begin{array}{l}\text { China } \\
\text { Africa } \\
\text { Central America } \\
\text { Hawaii }\end{array}$ & [21] \\
\hline Snake bites & WP & Pulverized herb & China & [21] \\
\hline
\end{tabular}

${ }^{\mathrm{b}}$ LE: leaves, ST: stem, FW: flower, WP: whole plant, RT: roots, AP: aerial parts.

in vitro studies have supported the claim that $B$. pilosa extracts and isolated compounds possess anti-cancer activities against a variety of cancer cells. Several studies have used bioassay guided isolation and fractionation methods to discover new compounds from $B$. pilosa. For example, Kviecinski and colleagues tested hydroalcoholic crude extracts, chloroform, ethyl acetate, and methanol fractions for anti-tumor activity [35]. The cytotoxicity of the extracts was assessed using brine shrimp, hemolytic, MTT, and neutral red uptake (NRU) assays. In vivo studies were performed using Ehrlich ascites carcinoma in isogenic BALB/c mice. Among them, the chloroform fraction was the most toxic with a half maximal inhibitory concentration $\left(\mathrm{IC}_{50}\right)$ of $97 \pm 7.2$ and $83 \pm$
$5.2 \mu \mathrm{g} / \mathrm{mL}$ in NRU and MTT, respectively [35]. Kumari and colleagues also reported the anti-cancer and anti-malarial activities of $B$. pilosa leaves [30]. Based on a cytotoxicitydirected fractionation strategy, they identified phenyl-1,3,5heptatriene with $\mathrm{IC}_{50}$ values of $8 \pm 0.01,0.49 \pm 0.45,0.7 \pm 0.01$, and $10 \pm 0.01 \mu \mathrm{g} / \mathrm{mL}$ against human oral, liver, colon, and breast cancer cell lines, respectively. However, phenyl-1,3,5heptatriyne showed lower activity against breast cancer cell lines than the chloroform leaf extract which had an $\mathrm{IC}_{50}$ value of $6.5 \pm 0.01 \mu \mathrm{g} / \mathrm{mL}$. Moreover, the positive control, taxol, showed higher activity than phenyl-1,3,5-heptatriyne [30]. Furthermore, in vitro comet assays were performed to evaluate the toxicity of n-hexane, chloroform, and methanol 
TABLE 4: Aliphatic natural products isolated from B. pilosa [27].

\begin{tabular}{|c|c|c|c|c|c|}
\hline S. N. & IUPAC names & Common names & Structure & $\begin{array}{l}\text { Plant part } \\
\text { (country) }\end{array}$ & References \\
\hline 1 & Heneicosane & & $\mathrm{CH}_{3}\left(\mathrm{CH}_{2}\right)_{19} \mathrm{CH}_{3}$ & Aerial (Tanzania) & {$[25]$} \\
\hline 2 & Docosane & & $\mathrm{CH}_{3}\left(\mathrm{CH}_{2}\right)_{20} \mathrm{CH}_{3}$ & Aerial (Tanzania) & {$[25]$} \\
\hline 3 & Tricosane & & $\mathrm{CH}_{3}\left(\mathrm{CH}_{2}\right)_{21} \mathrm{CH}_{3}$ & Aerial (Tanzania) & {$[25]$} \\
\hline 4 & Tetracosane & & $\mathrm{CH}_{3}\left(\mathrm{CH}_{2}\right)_{22} \mathrm{CH}_{3}$ & Aerial (Tanzania) & {$[25]$} \\
\hline 5 & Pentacosane & & $\mathrm{CH}_{3}\left(\mathrm{CH}_{2}\right)_{23} \mathrm{CH}_{3}$ & Aerial (Tanzania) & {$[25]$} \\
\hline 6 & Hexacosane & & $\mathrm{CH}_{3}\left(\mathrm{CH}_{2}\right)_{24} \mathrm{CH}_{3}$ & Aerial (Tanzania) & {$[25]$} \\
\hline 7 & Heptacosane & & $\mathrm{CH}_{3}\left(\mathrm{CH}_{2}\right)_{25} \mathrm{CH}_{3}$ & Aerial (Tanzania) & {$[25]$} \\
\hline 8 & Octacosone & & $\mathrm{CH}_{3}\left(\mathrm{CH}_{2}\right)_{26} \mathrm{CH}_{3}$ & $\begin{array}{l}\text { Aerial } \\
\text { (Tanzania); not } \\
\text { found } \\
\text { (Taiwan) }\end{array}$ & {$[25,58]$} \\
\hline 9 & Nonacosane & & $\mathrm{CH}_{3}\left(\mathrm{CH}_{2}\right)_{27} \mathrm{CH}_{3}$ & $\begin{array}{l}\text { Aerial } \\
\text { (Tanzania); not } \\
\text { found } \\
\text { (Taiwan) }\end{array}$ & {$[25,58]$} \\
\hline 10 & Triacontane & & $\mathrm{CH}_{3}\left(\mathrm{CH}_{2}\right)_{28} \mathrm{CH}_{3}$ & $\begin{array}{l}\text { Aerial } \\
\text { (Tanzania); not } \\
\text { found } \\
\text { (Taiwan) }\end{array}$ & {$[25,58]$} \\
\hline 11 & Hentriacontane & & $\mathrm{CH}_{3}\left(\mathrm{CH}_{2}\right)_{29} \mathrm{CH}_{3}$ & $\begin{array}{l}\text { Aerial } \\
\text { (Tanzania); not } \\
\text { found } \\
\text { (Taiwan) }\end{array}$ & {$[25,58]$} \\
\hline 12 & Dotriacontane & & $\mathrm{CH}_{3}\left(\mathrm{CH}_{2}\right)_{30} \mathrm{CH}_{3}$ & $\begin{array}{l}\text { Aerial } \\
\text { (Tanzania); not } \\
\text { found } \\
\text { (Taiwan) }\end{array}$ & {$[25,58]$} \\
\hline 13 & Tritriacontane & & $\mathrm{CH}_{3}\left(\mathrm{CH}_{2}\right)_{31} \mathrm{CH}_{3}$ & $\begin{array}{l}\text { Aerial } \\
\text { (Tanzania); not } \\
\text { found } \\
\text { (Taiwan) }\end{array}$ & {$[25,58]$} \\
\hline 14 & 2-Butoxy-ethanol & & $\mathrm{CH}_{3}\left(\mathrm{CH}_{2}\right)_{3} \mathrm{OCH}_{2} \mathrm{CH}_{2} \mathrm{OH}$ & Whole (Taiwan) & {$[59]$} \\
\hline 15 & Tetracosan-1-ol & & $\mathrm{CH}_{3}\left(\mathrm{CH}_{2}\right)_{22} \mathrm{CH}_{2} \mathrm{OH}$ & Aerial (Tanzania) & {$[25]$} \\
\hline 16 & Hexacosan-1-ol & & $\mathrm{CH}_{3}\left(\mathrm{CH}_{2}\right)_{24} \mathrm{CH}_{2} \mathrm{OH}$ & Aerial (Tanzania) & {$[25]$} \\
\hline 17 & 1-Octacosanol & & $\mathrm{CH}_{3}\left(\mathrm{CH}_{2}\right)_{26} \mathrm{CH}_{2} \mathrm{OH}$ & Aerial (Tanzania) & {$[25]$} \\
\hline 18 & 1-Hentriacontanol & & $\mathrm{CH}_{3}\left(\mathrm{CH}_{2}\right)_{29} \mathrm{CH}_{2} \mathrm{OH}$ & $\begin{array}{l}\text { Not found } \\
\text { (Taiwan) }\end{array}$ & [58] \\
\hline 19 & Tetradecanoic acid & Myristic acid & $\mathrm{CH}_{3}\left(\mathrm{CH}_{2}\right)_{12} \mathrm{CO}_{2} \mathrm{H}$ & Aerial (Tanzania) & {$[25]$} \\
\hline 20 & Hexadecanoic acid & Palmitic acid & $\mathrm{CH}_{3}\left(\mathrm{CH}_{2}\right)_{14} \mathrm{CO}_{2} \mathrm{H}$ & Aerial (Tanzania) & {$[25]$} \\
\hline 21 & Octadecanoic acid & Stearic acid & $\mathrm{CH}_{3}\left(\mathrm{CH}_{2}\right)_{16} \mathrm{CO}_{2} \mathrm{H}$ & Aerial (Tanzania) & {$[25]$} \\
\hline 22 & Eicosanoic acid & Arachidic acid & $\mathrm{CH}_{3}\left(\mathrm{CH}_{2}\right)_{18} \mathrm{CO}_{2} \mathrm{H}$ & Aerial (Tanzania) & {$[25]$} \\
\hline 23 & Docosanoic acid & Behenic acid & $\mathrm{CH}_{3}\left(\mathrm{CH}_{2}\right)_{20} \mathrm{CO}_{2} \mathrm{H}$ & $\begin{array}{l}\text { Leaves } \\
\text { (Philippines) }\end{array}$ & {$[60]$} \\
\hline 24 & 2-butenedioic acid & & & Aerial (China) & {$[61,62]$} \\
\hline 25 & $\begin{array}{l}\text { (Z)-9-Octadecenoic } \\
\text { acid }\end{array}$ & Oleic acid & & Aerial (Tanzania) & {$[25]$} \\
\hline
\end{tabular}


TABLE 4: Continued.

\begin{tabular}{|c|c|c|c|c|c|}
\hline S. N & IUPAC names & Common names & Structure & $\begin{array}{l}\text { Plant part } \\
\text { (country) }\end{array}$ & References \\
\hline 26 & $\begin{array}{l}\text { (E)-9-Octadecenoic } \\
\text { acid }\end{array}$ & Elaidic acid & & $\begin{array}{l}\text { Leaves } \\
\text { (Philippines) }\end{array}$ & {$[60]$} \\
\hline 27 & $\begin{array}{l}(Z, Z)-9,12- \\
\text { Octadecadienoic acid }\end{array}$ & $\begin{array}{c}\text { Linolic acid or Linoleic } \\
\text { acid }\end{array}$ & & $\begin{array}{l}\text { Aerial } \\
\text { (Tanzania); } \\
\text { whole (Taiwan) }\end{array}$ & {$[25,63]$} \\
\hline 28 & $\begin{array}{l}(Z, Z, Z)-9,12,15- \\
\text { Octadecatrienoic } \\
\text { acid }\end{array}$ & $\alpha$-Linoleic acid & & Whole (Taiwan) & [59] \\
\hline 29 & $\begin{array}{l}(Z, Z)-9,12- \\
\text { Octadecadienoic acid, } \\
\text { ethyl ester }\end{array}$ & Ethyl linoleate & & Whole (Taiwan) & [59] \\
\hline 30 & $\begin{array}{l}(Z, Z, Z)-9,12,15- \\
\text { Octadecatrienoic } \\
\text { acid, methyl ester }\end{array}$ & Methyl linolenate & & Whole (Taiwan) & [59] \\
\hline 31 & $\begin{array}{l}(Z, Z, Z)-9,12,15- \\
\text { Octadecatrienoic } \\
\text { acid, ethyl ester }\end{array}$ & Ethyl linolenate & & Whole (Taiwan) & [59] \\
\hline 32 & $\begin{array}{l}(Z) \text {-9-Octadecenoic } \\
\text { acid, 2-butoxyethyl } \\
\text { ester }\end{array}$ & 2-Butoxyethyl oleate & & Whole (Taiwan) & [59] \\
\hline 33 & $\begin{array}{l}\text { 2-Butoxyethyl } \\
\text { linoleate }\end{array}$ & & & Whole (Taiwan) & [59] \\
\hline 34 & $\begin{array}{l}(Z, Z, Z)-9,12,15- \\
\text { Octadecatrienoic } \\
\text { acid, butoxyethyl ester }\end{array}$ & 2-Butoxyethyl linoleate & & Whole (Taiwan) & [59] \\
\hline 35 & $\begin{array}{l}1,7 E, 9 E, 15 E- \\
\text { Heptadecatetraene- } \\
\text { 11,13-diyne }\end{array}$ & $\begin{array}{l}\text { Heptadeca-2E,8E,10E, } \\
\text { 16-tetraen-4,6-diyne }\end{array}$ & & $\begin{array}{l}\text { Not found } \\
\text { (China) }\end{array}$ & {$[64]$} \\
\hline
\end{tabular}


TABle 4: Continued.

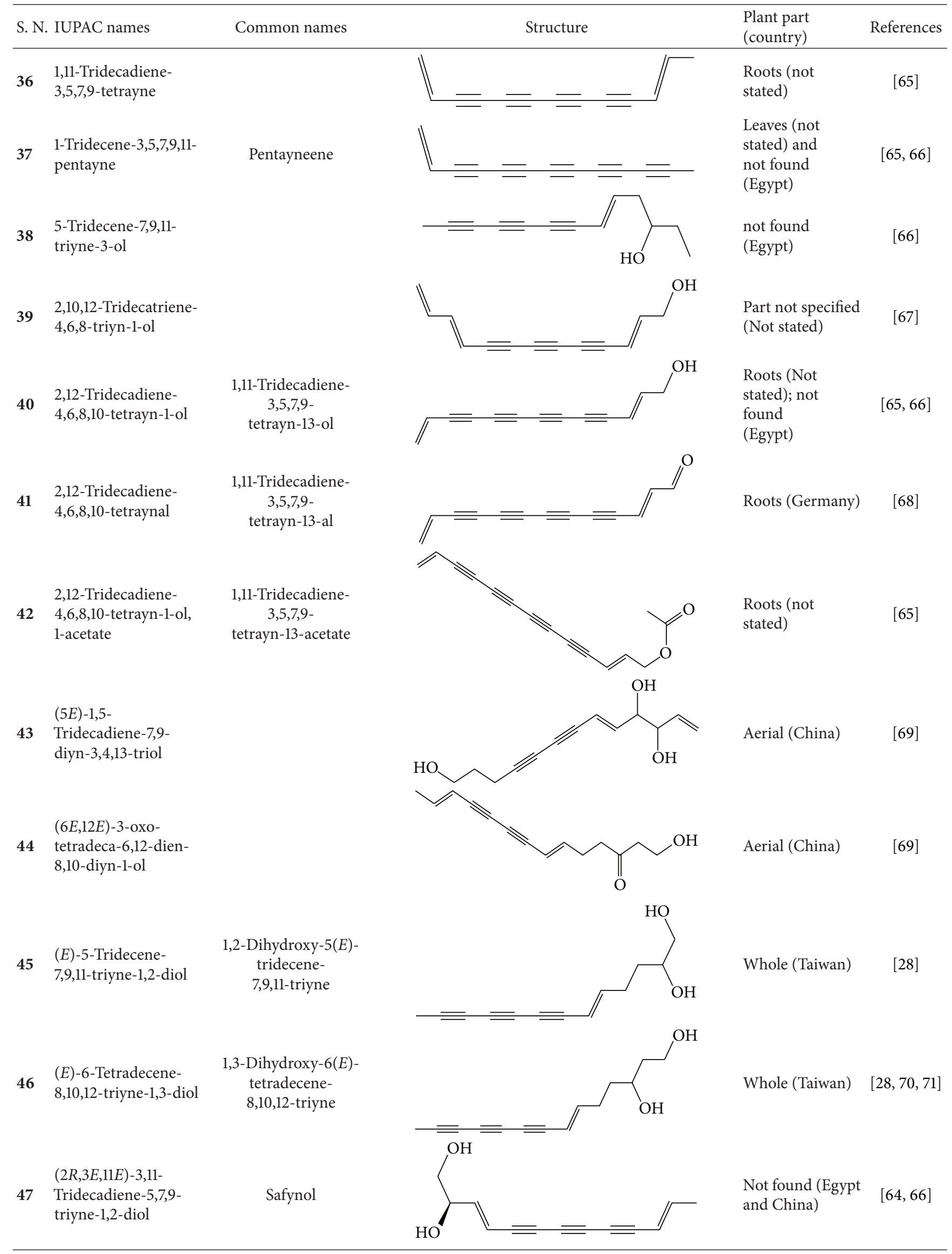


TABLE 4: Continued.

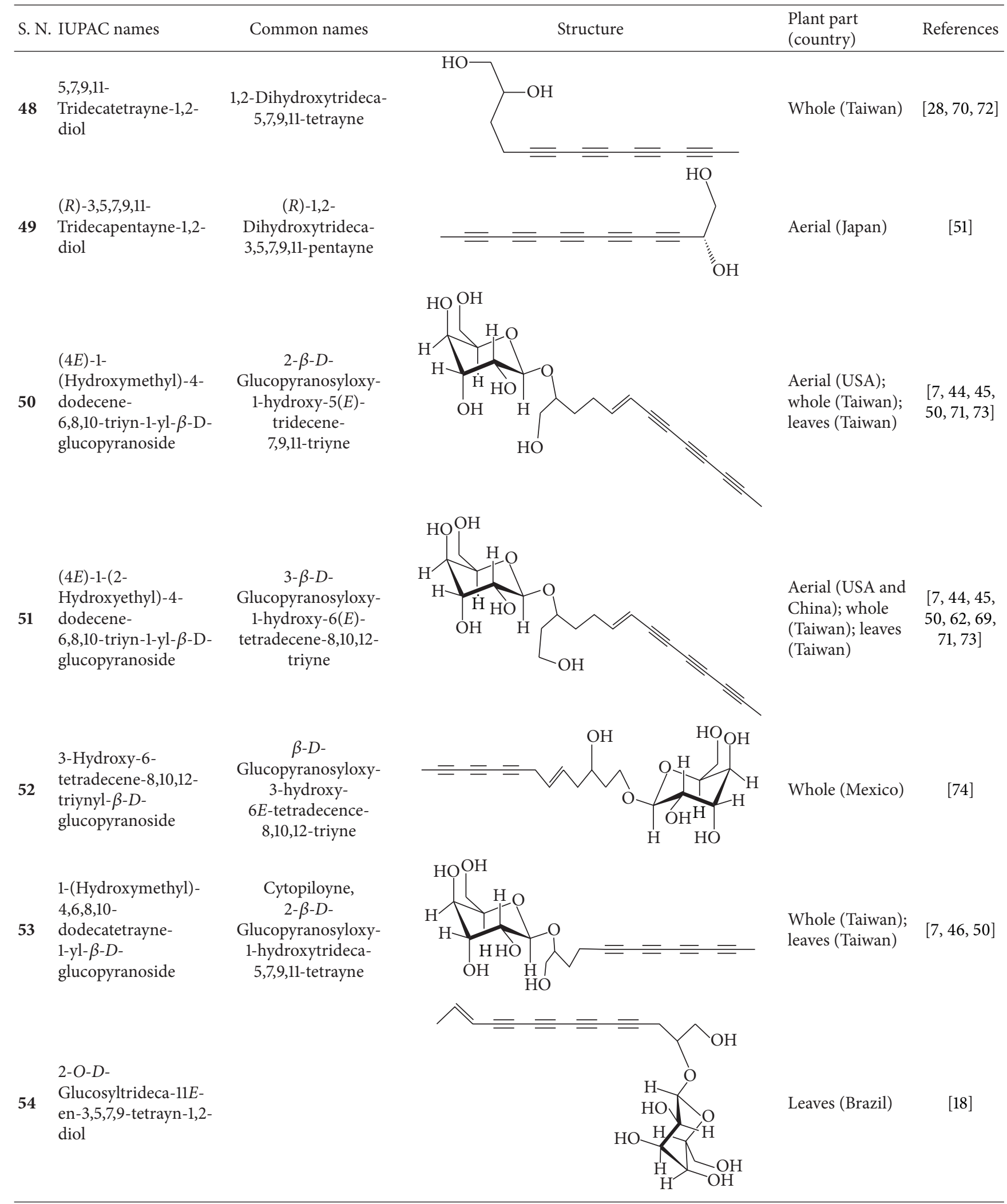


TABLE 4: Continued.

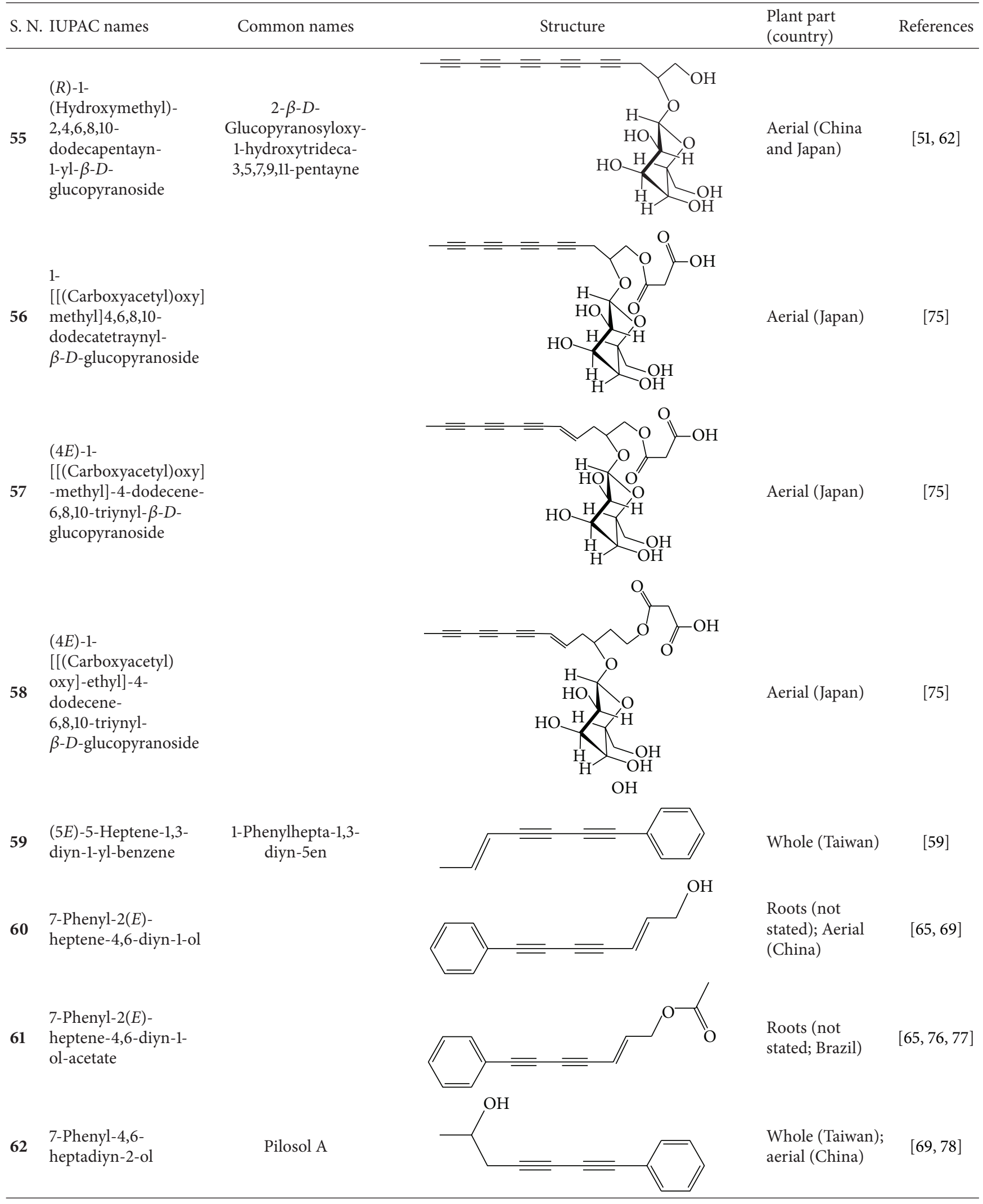


TABLE 4: Continued.

\begin{tabular}{|c|c|c|c|c|c|}
\hline \multicolumn{2}{|c|}{ S. N. IUPAC names } & \multirow[t]{2}{*}{ Common names } & \multirow[t]{2}{*}{ Structure } & $\begin{array}{l}\text { Plant part } \\
\text { (country) }\end{array}$ & References \\
\hline 63 & $\begin{array}{l}\text { 7-Phenylhepta-4,6- } \\
\text { diyn-1,2-diol }\end{array}$ & & & Aerial (China) & [69] \\
\hline 64 & $\begin{array}{l}\text { 1,3,5-Heptatriyn-1-yl- } \\
\text { benzene }\end{array}$ & $\begin{array}{l}\text { 1-Phenylhepta-1,3,5- } \\
\text { triyne }\end{array}$ & $\overline{\bar{\nu}}$ & $\begin{array}{l}\text { Leaves (not } \\
\text { stated); leaves of } \\
\text { tissue culture } \\
\text { (not stated); } \\
\text { aerial (Tanzania; } \\
\text { China); } \\
\text { Whole (Taiwan); } \\
\text { roots (Brazil) }\end{array}$ & $\begin{array}{l}{[25,61,65} \\
69,77-79]\end{array}$ \\
\hline 65 & $\begin{array}{l}\text { 7-Phenyl-2,4,6- } \\
\text { heptatriyn-1-ol }\end{array}$ & & & $\begin{array}{l}\text { Leaves (not } \\
\text { stated); aerial } \\
\text { (China) }\end{array}$ & {$[65,69]$} \\
\hline 66 & $\begin{array}{l}\text { 7-Phenyl-2,4,6- } \\
\text { heptatriyn-1-ol- } \\
\text { acetate }\end{array}$ & & & $\begin{array}{l}\text { Leaves (not } \\
\text { stated) }\end{array}$ & {$[65]$} \\
\hline 67 & $\begin{array}{l}\text { 5-(2-Phenylethynyl)- } \\
\text { 2-thiophene } \\
\text { methanol }\end{array}$ & & & Aerial (China) & [69] \\
\hline 68 & $\begin{array}{l}\text { 5-(2-Phenylethynyl)- } \\
2 \beta \text {-glucosylmethyl- } \\
\text { thiophene }\end{array}$ & & & Aerial (China) & [69] \\
\hline 69 & $\begin{array}{l}\text { 3- } \beta-D- \\
\text { Glucopyranosyl-1- } \\
\text { hydroxy-6(E)- } \\
\text { tetradecene-8,10,12- } \\
\text { triyne }\end{array}$ & & & $\begin{array}{l}\text { Leaves } \\
\text { (Cameroon) }\end{array}$ & [19] \\
\hline 70 & $\begin{array}{l}\text { 1-Phenyl-1,3-diyn-5- } \\
\text { en-7-ol-acetate }\end{array}$ & & & Leaves (Brazil) & {$[18]$} \\
\hline
\end{tabular}

S.N. denotes serial number.

extracts of $B$. pilosa and its ethyl acetate, acetone, and water fractions on Hela and KB cells. The ethyl acetate fraction from the methanol extract exhibited the highest activity with half maximal cytotoxic concentrations $\left(\mathrm{CTC}_{50}\right)$ of $965.2 \mu \mathrm{g} / \mathrm{mL}$ and $586.2 \mu \mathrm{g} / \mathrm{mL}$ against Hela and $\mathrm{KB}$ cells, respectively. Despite the moderate toxicity, these findings suggest that these B. pilosa extracts/fractions could be useful for future studies [36]. Hot water extracts of B. pilosa var. minor Sheriff were also assessed for its antileukemic effects on leukemic cell lines L1210, U937, K562, Raji, and P3HR1 using XTTbased colorimetric assays. The extract inhibited the five cell lines with $\mathrm{IC}_{50}$ values ranging from $145 \mu \mathrm{g} / \mathrm{mL}$ to $586 \mu \mathrm{g} / \mathrm{mL}$. L1210, K562, Raji, and P3HR1 were more sensitive to B. pilosa extract with $\mathrm{IC}_{50}$ values below $200 \mu \mathrm{g} / \mathrm{mL}$ [101].

Consistent with the antitumor activities of $B$. pilosa extracts and fractions, some of its phytochemicals also showed anticancer activity as outlined in Table 11. Among them, luteolin (103), a well-studied flavonoid with multiple bioactivities, was more effective against tumor cell proliferation than its derivatives with $\mathrm{IC}_{50}$ values ranging from $3 \mu \mathrm{M}$ to $50 \mu \mathrm{M}$ in cells, and 5 to $10 \mathrm{mg} / \mathrm{kg}$ in animals. Luteolin was also found to fight cancer as a food additive at concentrations 


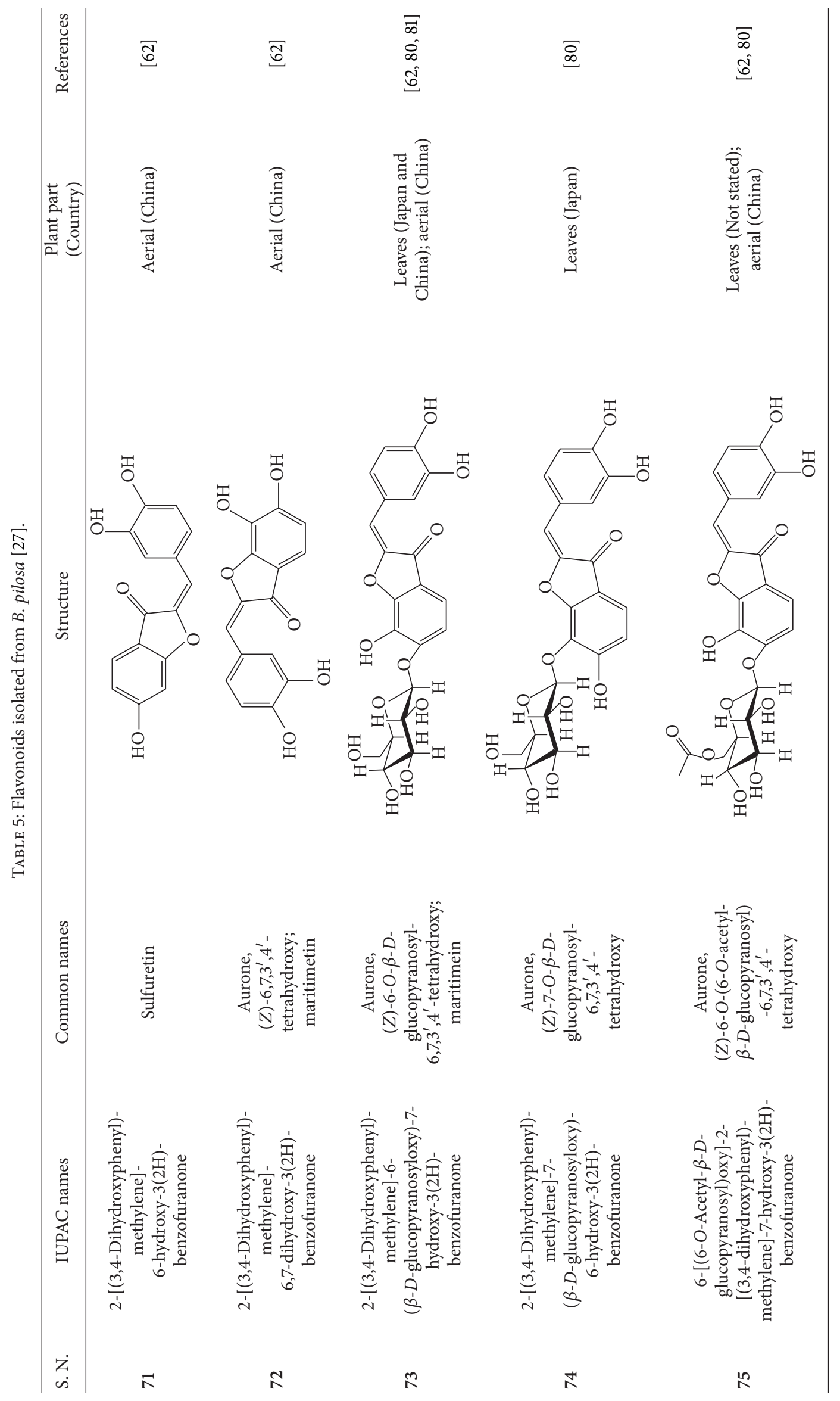




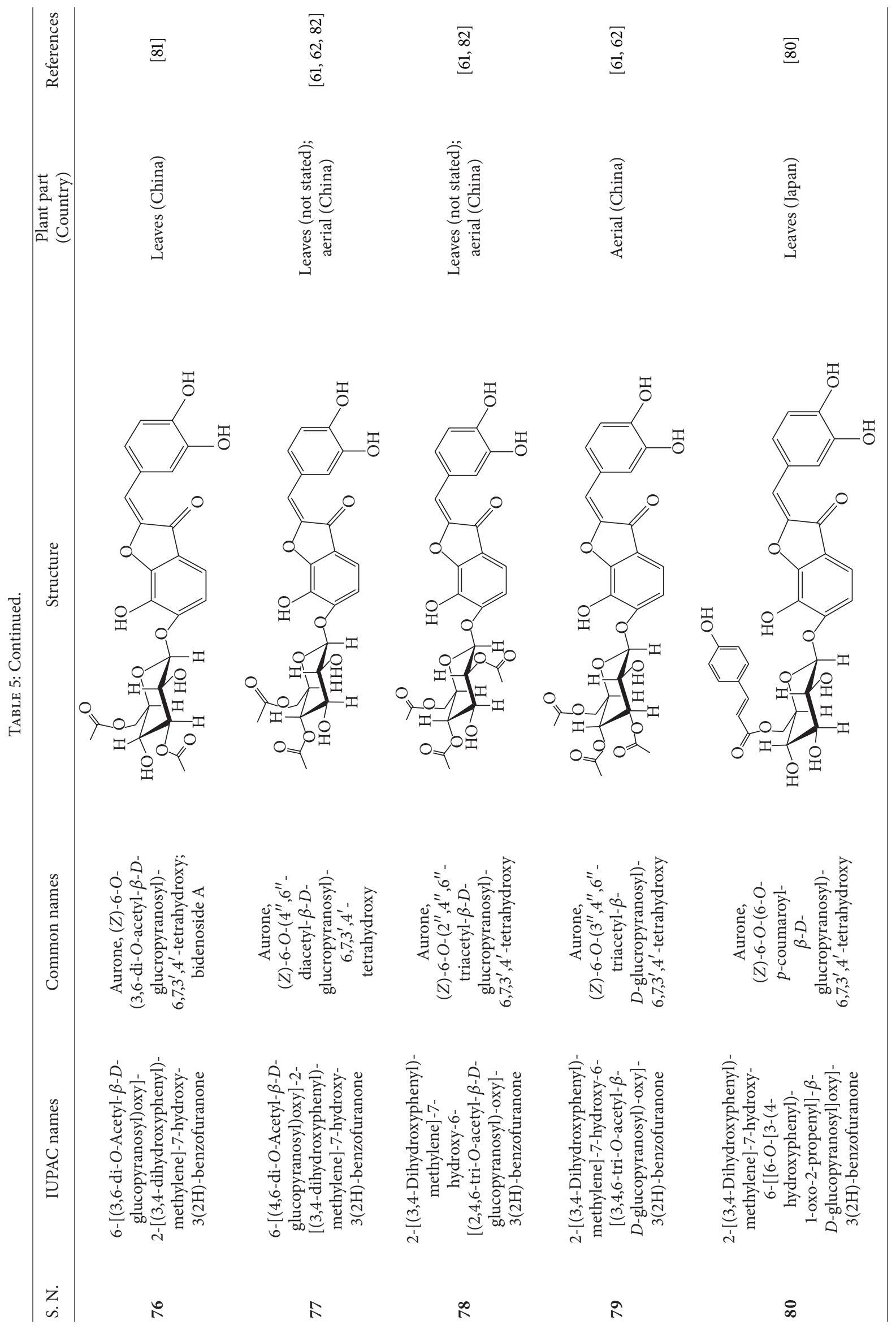




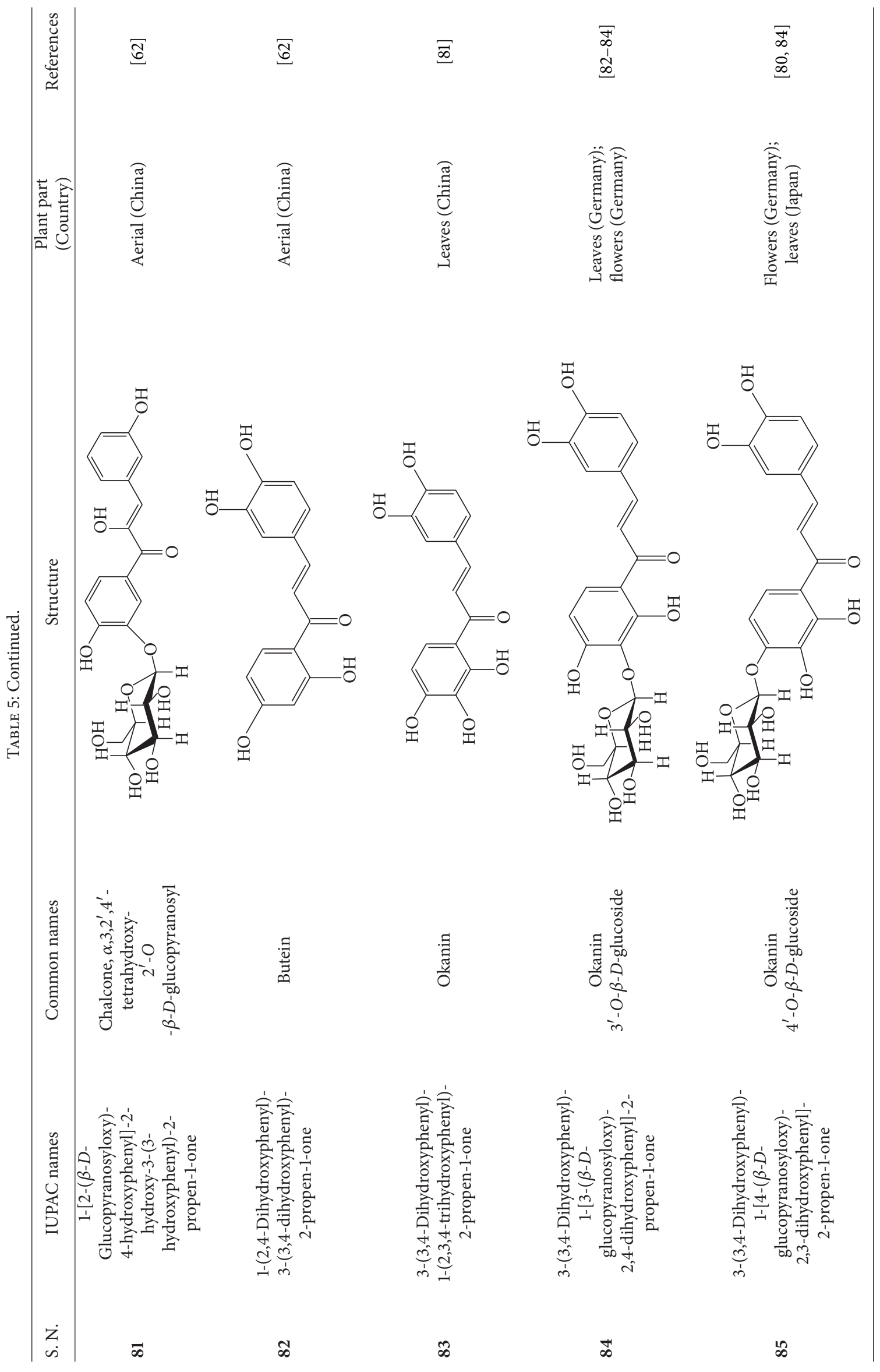




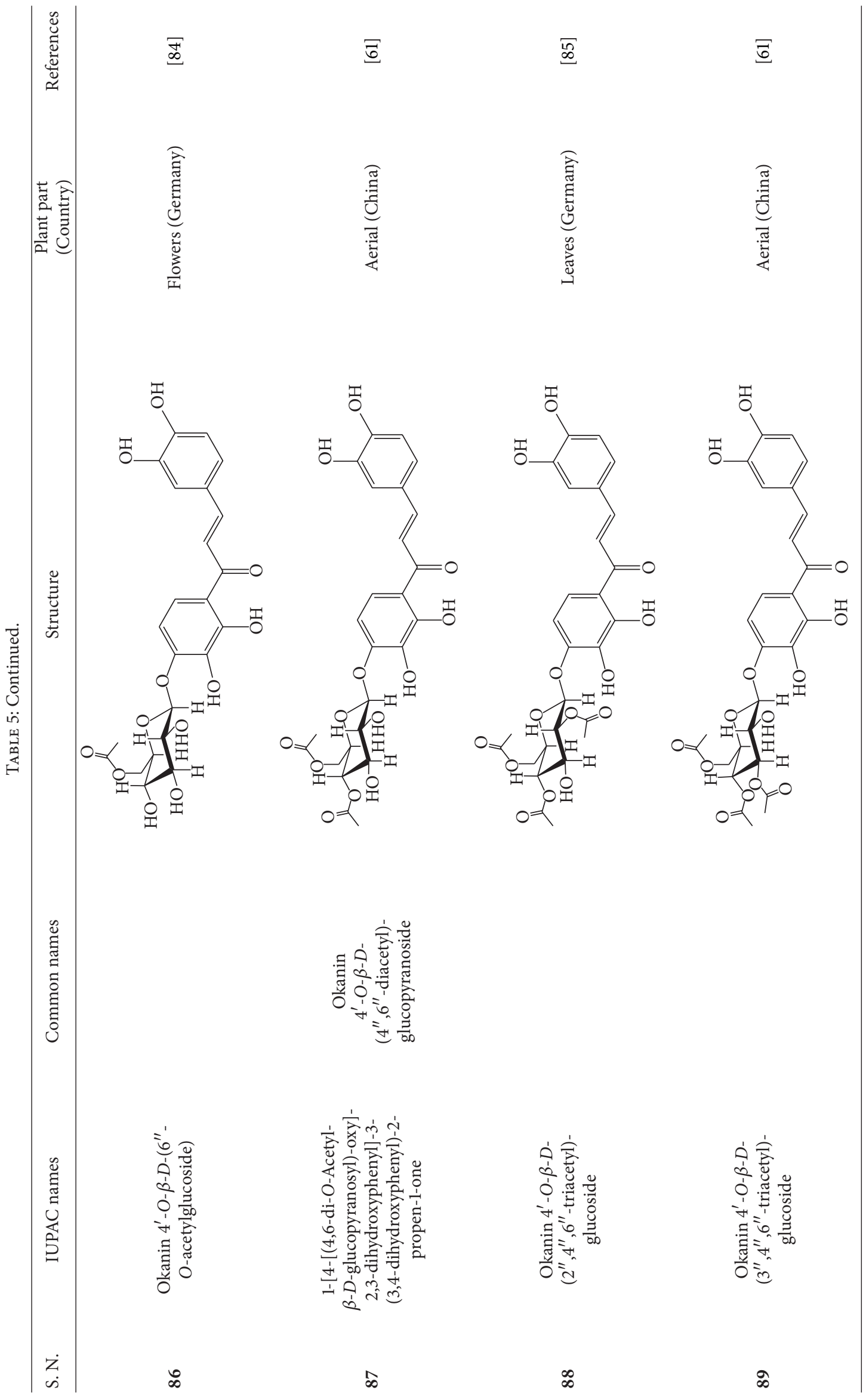




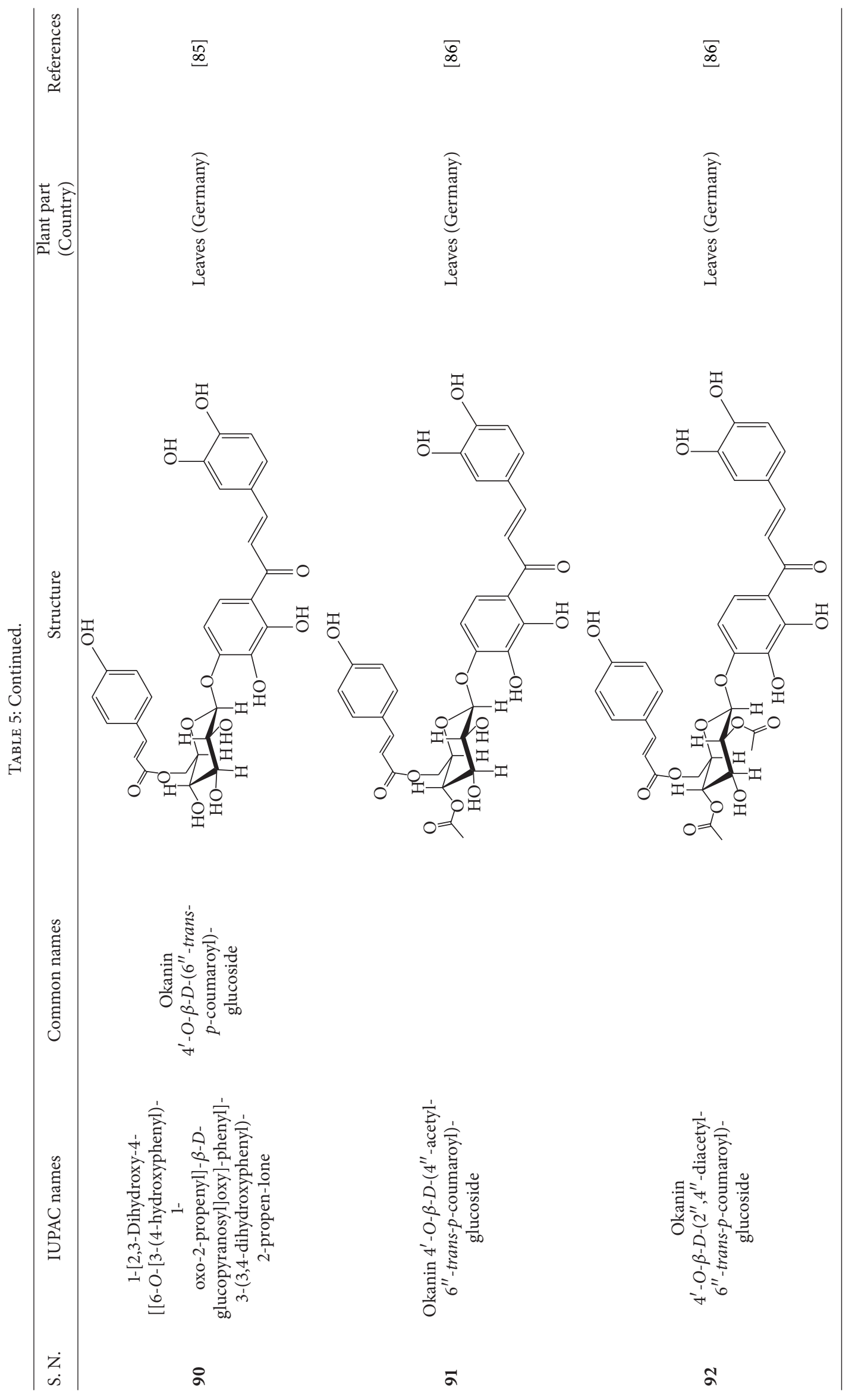




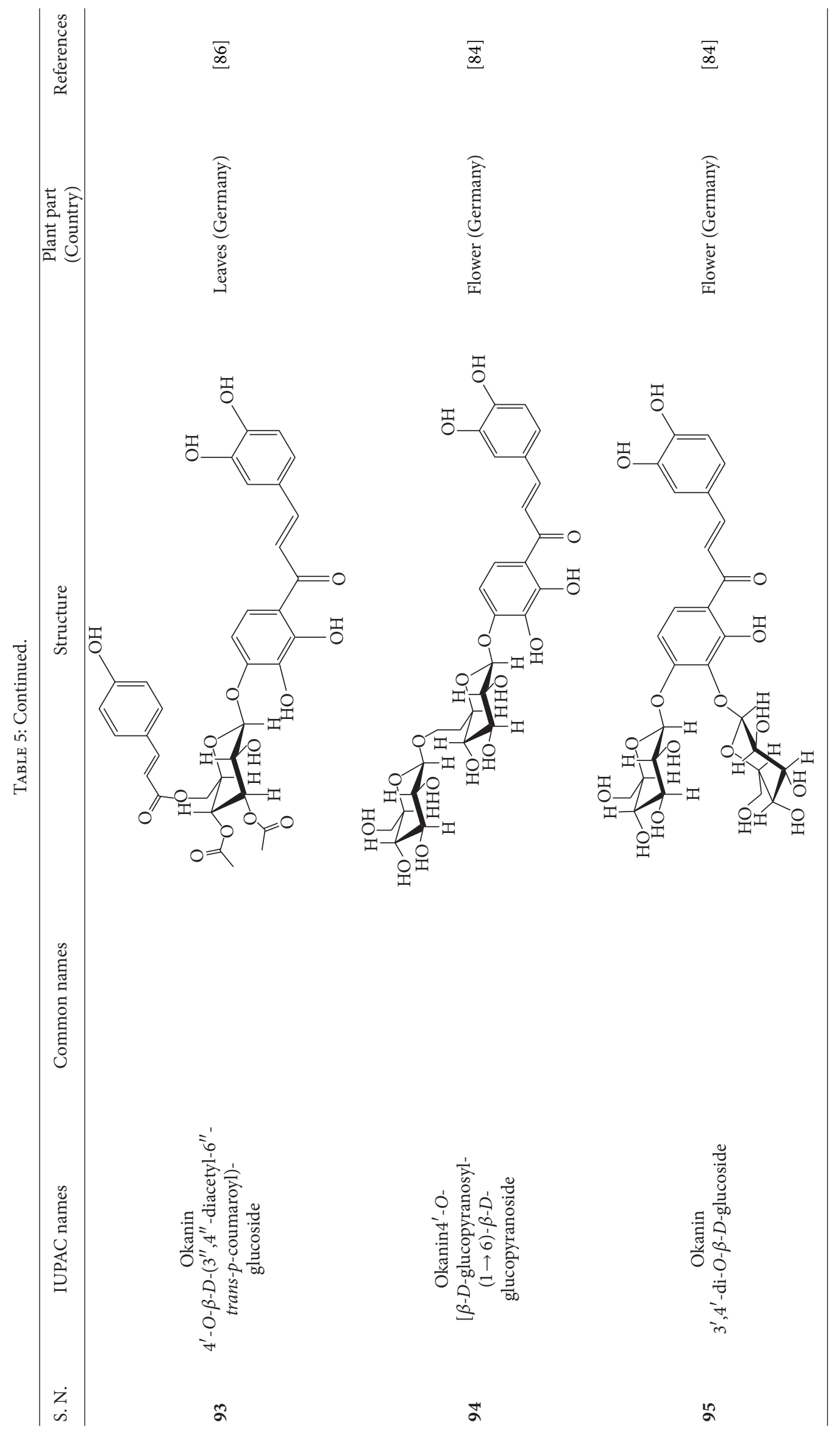




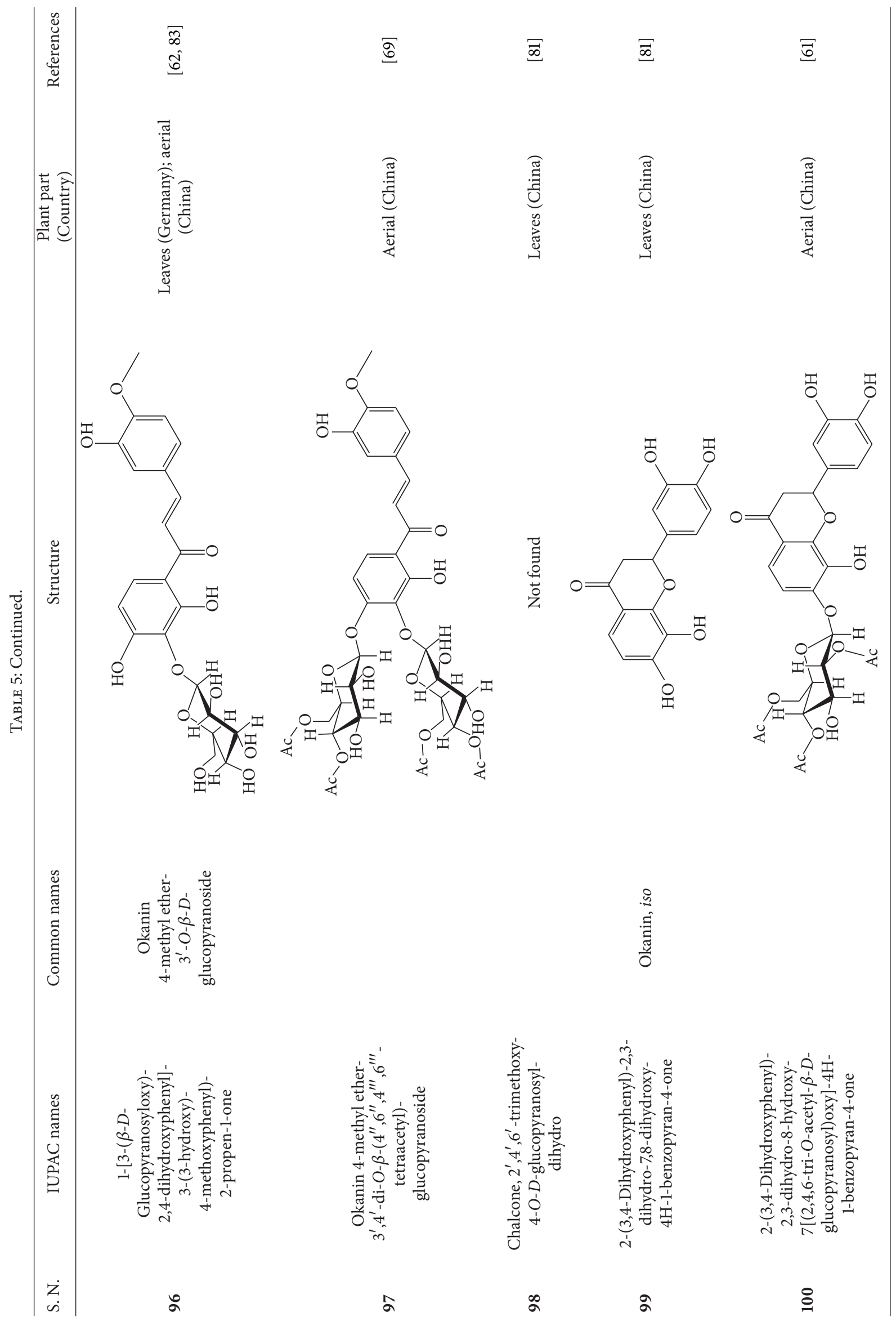




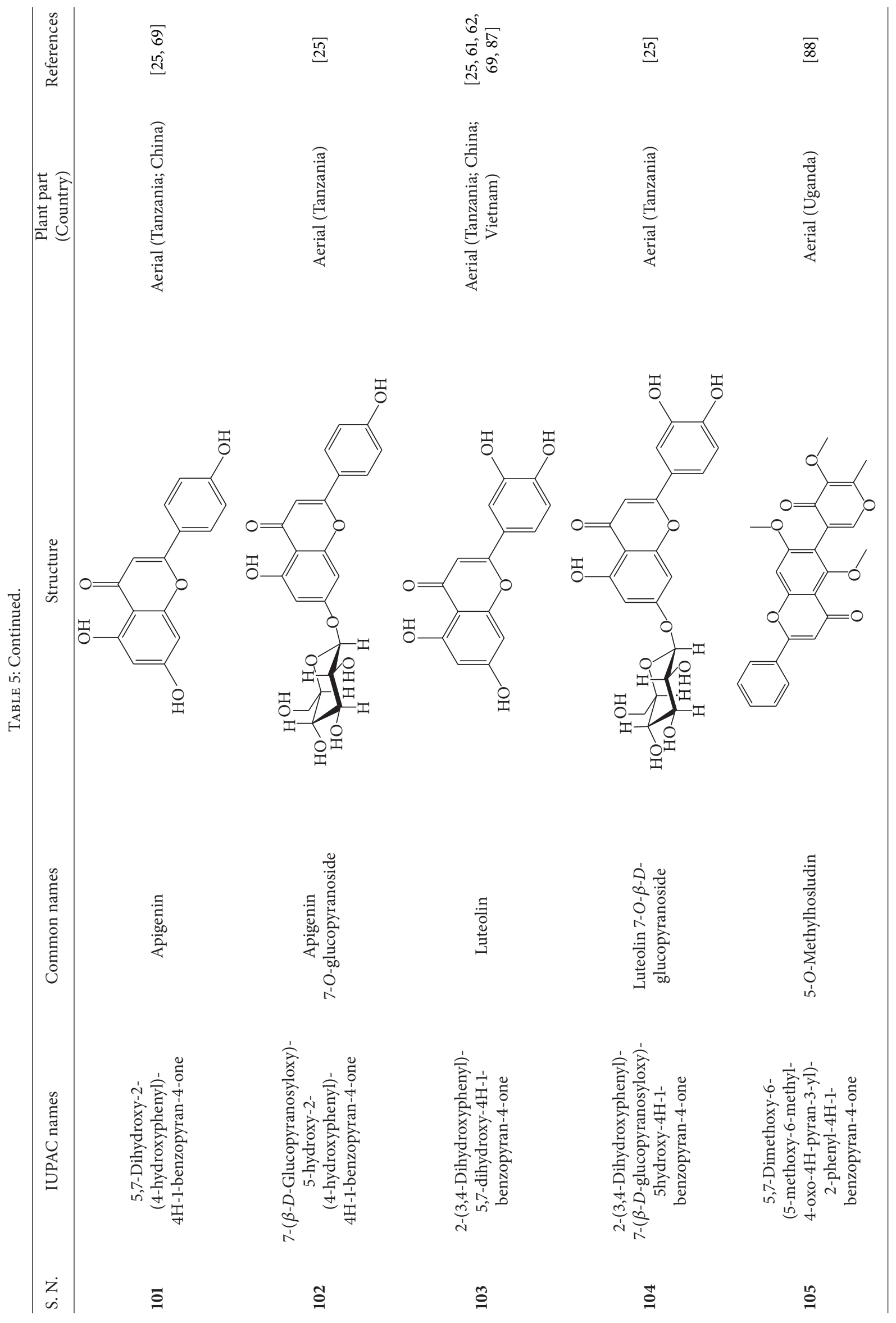




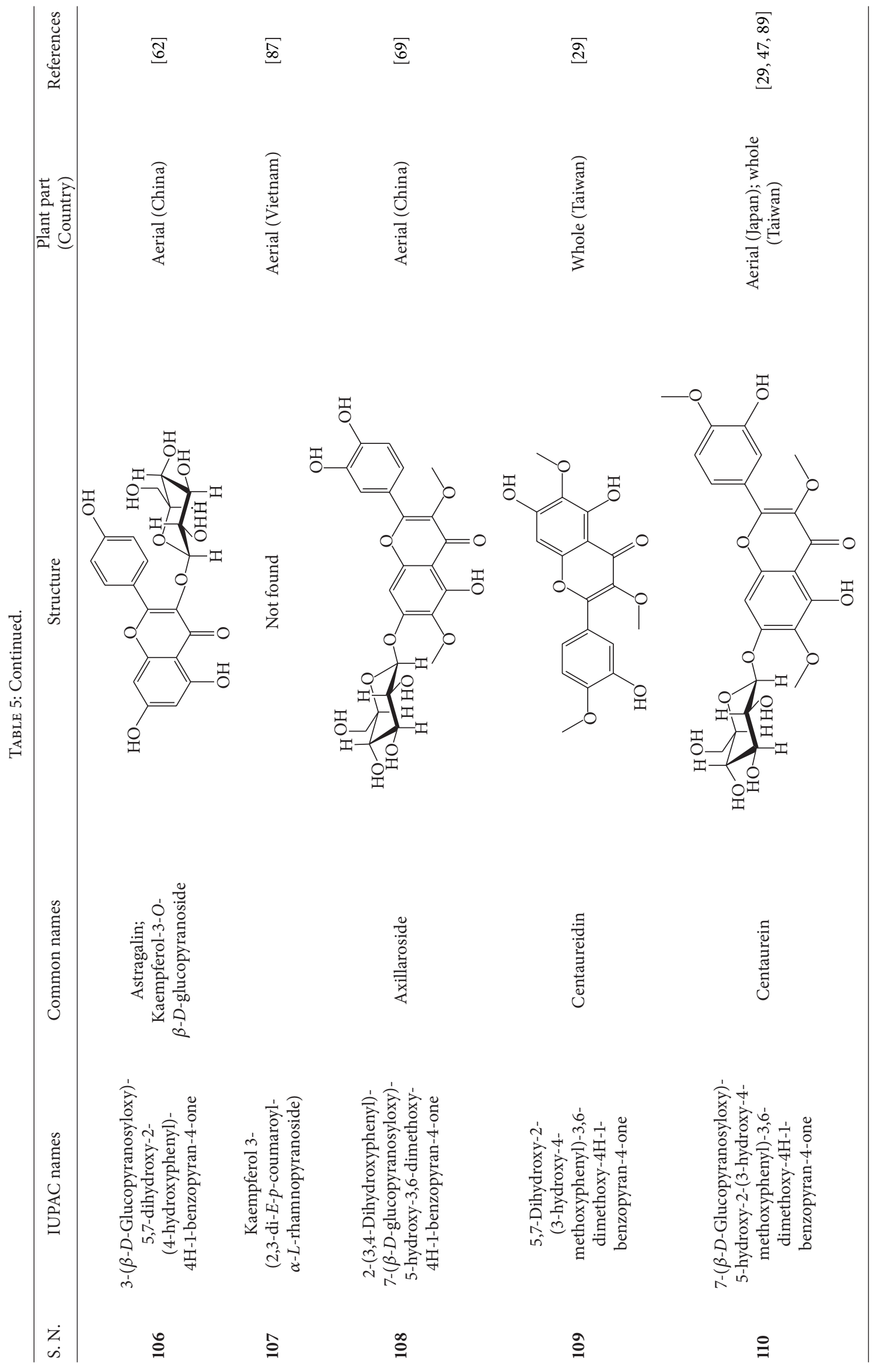




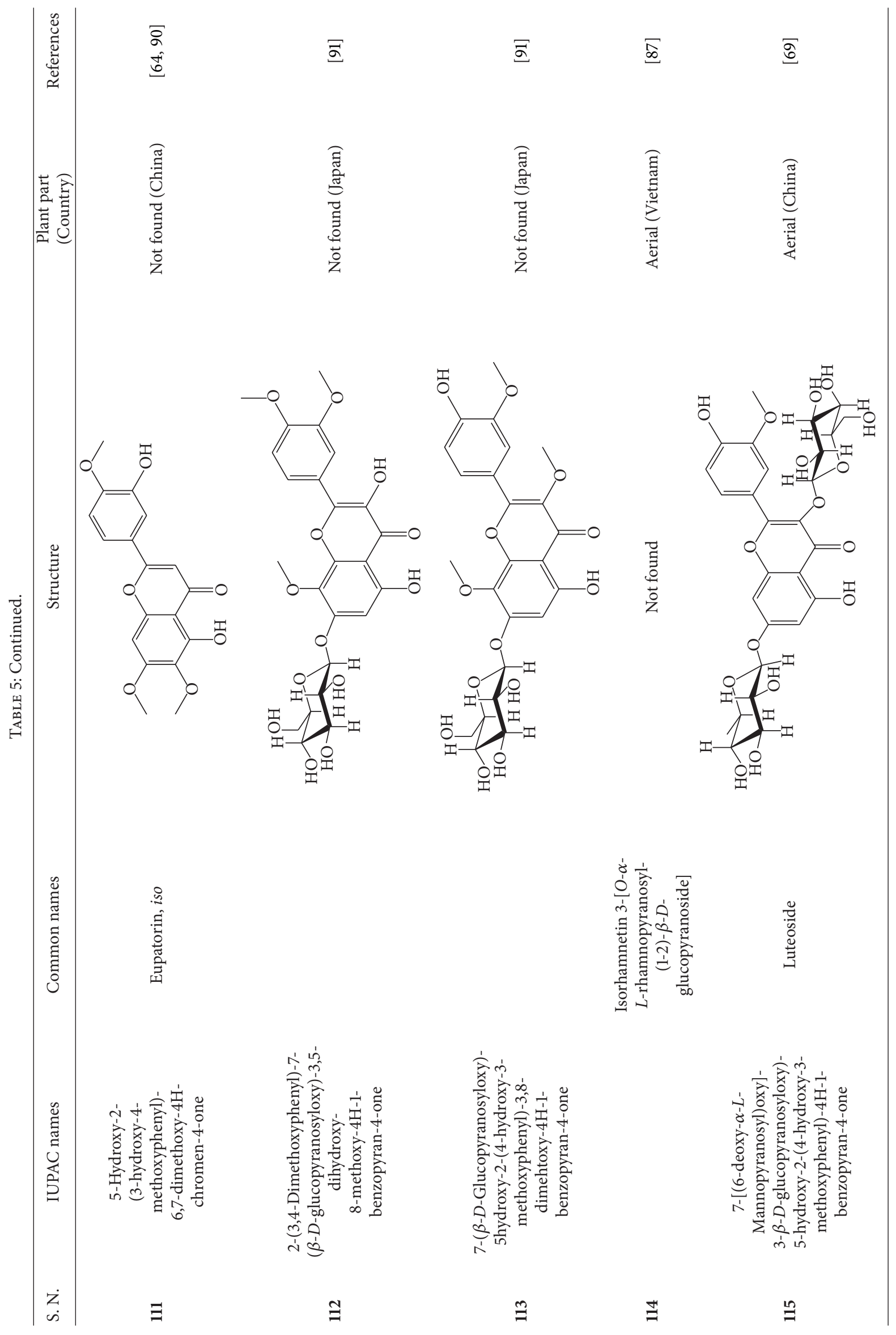




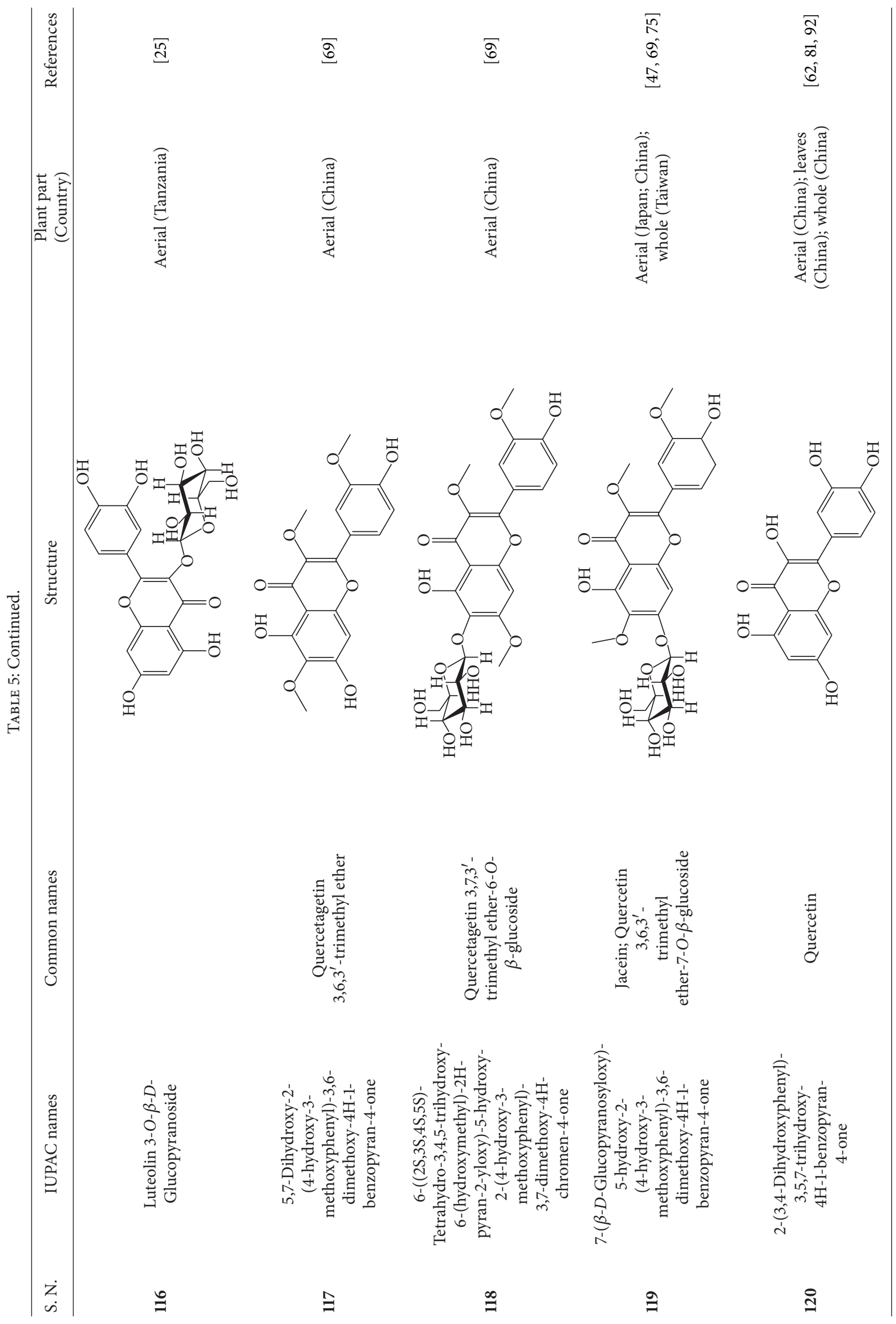




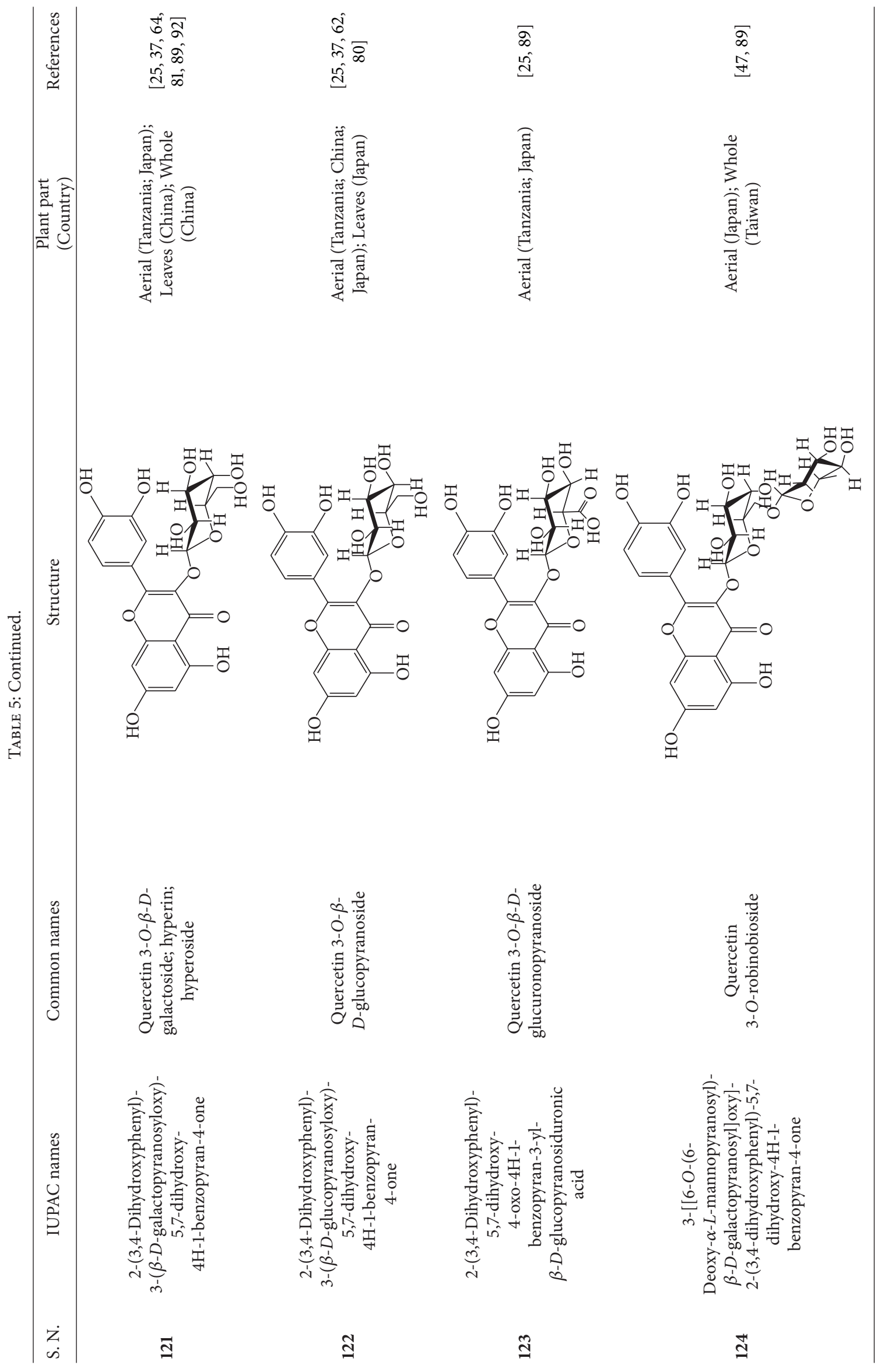




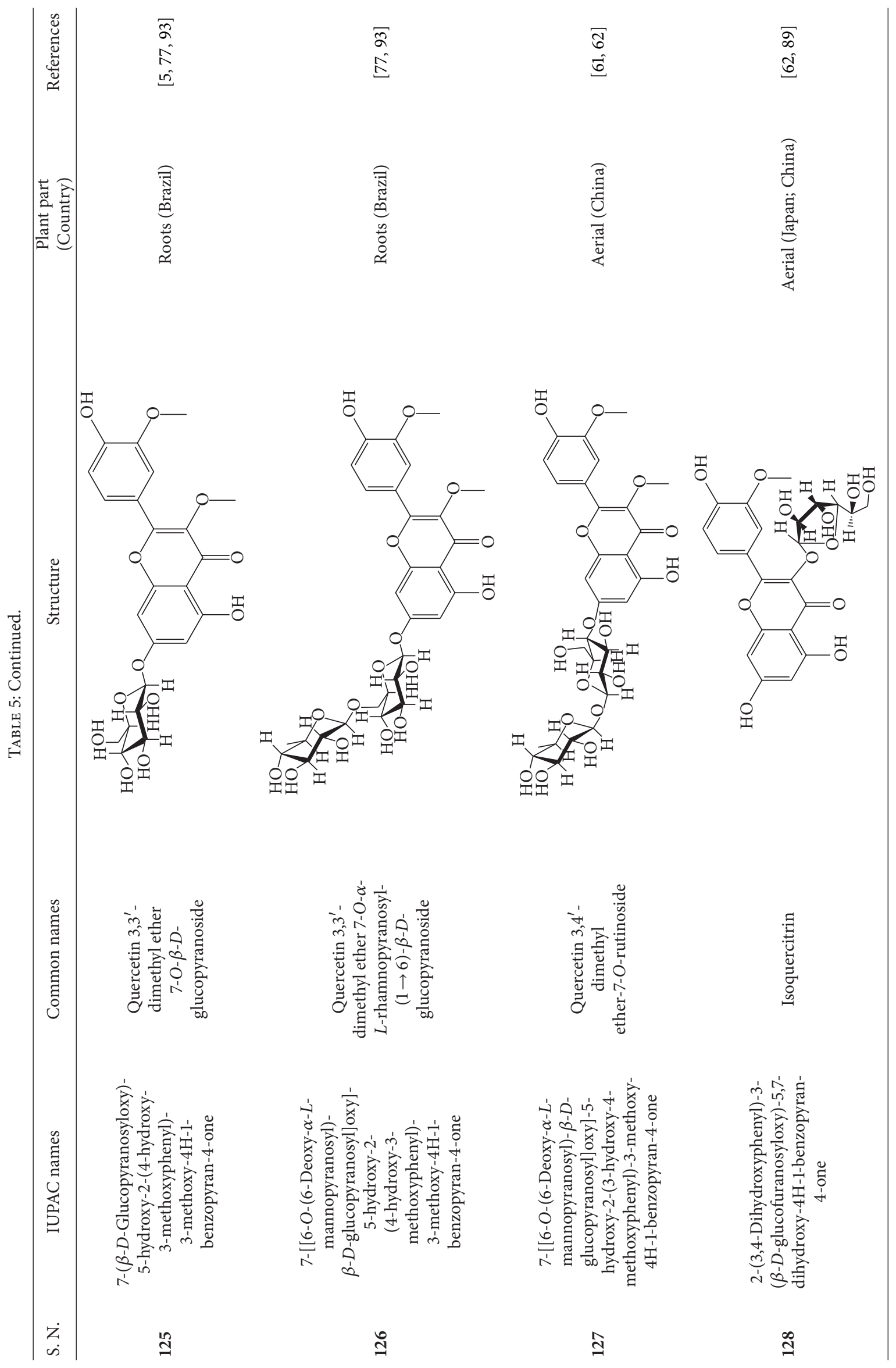




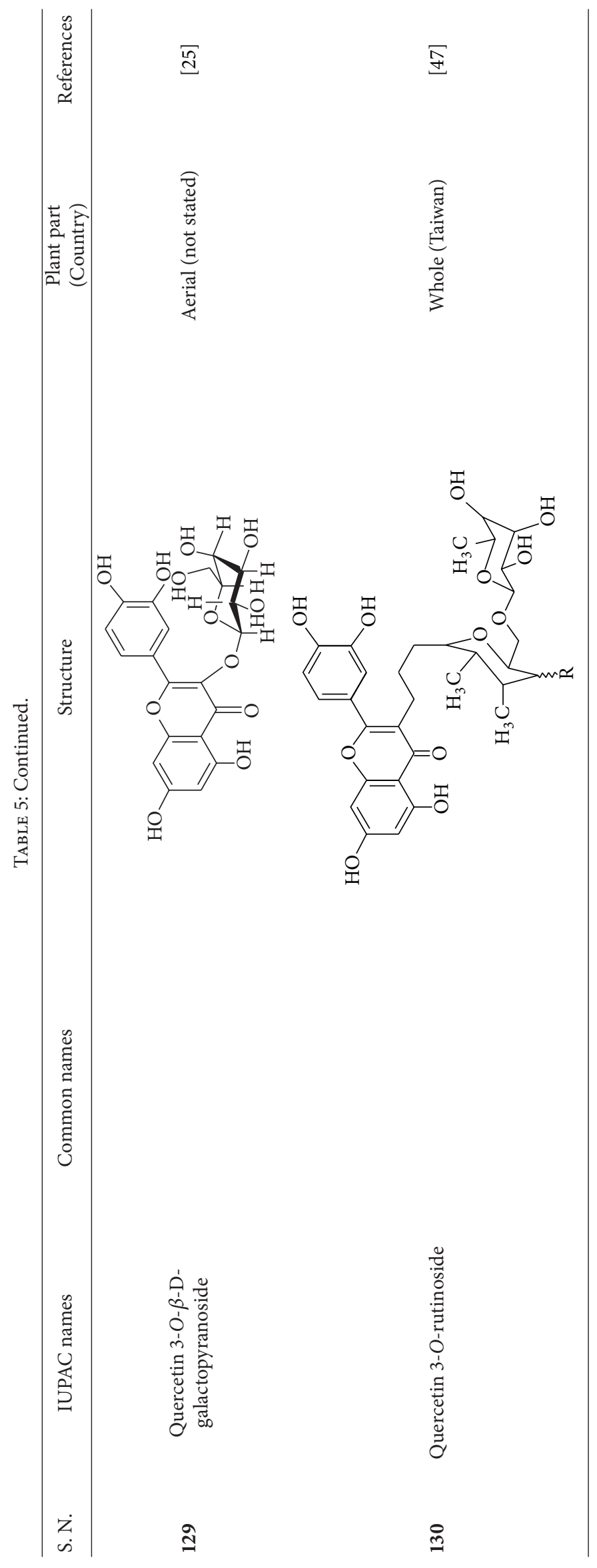


TABLE 6: Terpenoids isolated from B. pilosa [27].

\begin{tabular}{|c|c|c|c|c|c|}
\hline S. N. & IUPAC names & Common names & Structure & $\begin{array}{l}\text { Plant part } \\
\text { (Country) }\end{array}$ & References \\
\hline 131 & $\begin{array}{c}\text { 3,7,11,11-Tetramethylbicyclo } \\
{[8.1 .0] \text { undeca- }} \\
\text { 2,6-diene }\end{array}$ & Bicyclogermacrene & & $\begin{array}{l}\text { Leaves } \\
\text { (Brazil) }\end{array}$ & {$[94]$} \\
\hline 132 & $\begin{array}{l}\text { 4,11,11-Trimethyl-8- } \\
\text { methylenebicyclo[7.2.0] undec- } \\
\text { 4-ene }\end{array}$ & E-Caryophyllene & & $\begin{array}{l}\text { Leaves } \\
\text { (Brazil) }\end{array}$ & {$[94]$} \\
\hline 133 & $\begin{array}{l}\text { 1-Methyl-5-methylene-8- } \\
\text { (1-methylethyl)-1,6- } \\
\text { cyclodecadiene }\end{array}$ & Germacrene D & & $\begin{array}{l}\text { Leaves } \\
\text { (Brazil) }\end{array}$ & {$[94]$} \\
\hline 134 & $\begin{array}{l}\text { 4-(1,5-Dimethyl-4- } \\
\text { hexen-1-ylidene)-1- } \\
\text { methyl-cyclohexene }\end{array}$ & $Z$ - $\gamma$-Bisabolene & & $\begin{array}{l}\text { Leaves } \\
\text { (Brazil) }\end{array}$ & {$[94]$} \\
\hline 135 & $\begin{array}{l}\text { Decahydro-1,1,4-trimethyl-7- } \\
\text { methylene-1H-cycloprop[e]- } \\
\text { azulene }\end{array}$ & $\beta$-Gurjunene & & $\begin{array}{l}\text { Leaves } \\
\text { (Brazil) }\end{array}$ & {$[94]$} \\
\hline 136 & $\begin{array}{l}\text { 2,6,6,9-Tetramethyl-1,4,8- } \\
\text { cycloundecatriene }\end{array}$ & $\begin{array}{c}\alpha \text {-Humulene; } \\
\alpha \text {-caryophyllene }\end{array}$ & & $\begin{array}{l}\text { Leaves } \\
\text { (Brazil) }\end{array}$ & {$[94]$} \\
\hline 137 & $\begin{array}{l}\text { 1,2,3,4,4a,5,6,8a-Octahydro- } \\
\text { 1-isopropyl-7-methyl-4- } \\
\text { methylenenaphthalene }\end{array}$ & $\delta$-Muurolene & & $\begin{array}{l}\text { Leaves } \\
\text { (Brazil) }\end{array}$ & {$[94]$} \\
\hline 138 & $\begin{array}{c}1,2,3,4,4 a, 5,6,8 \mathrm{a}- \\
\text { Octahydro-4a,8-dimethyl- } \\
\text { 2-(1-methylethylidene)- } \\
\text { naphthalene }\end{array}$ & $\begin{array}{l}\text { Selina-3,7(11)- } \\
\text { diene }\end{array}$ & & $\begin{array}{l}\text { Leaves } \\
\text { (Brazil) }\end{array}$ & {$[94]$} \\
\hline 139 & $\begin{array}{l}(2 E, 7 R, 11 R)-3,7,11,15- \\
\text { Tetramethyl-2- } \\
\text { hexadecen-1-ol }\end{array}$ & Phytol & & $\begin{array}{l}\text { Whole } \\
\text { (Taiwan) }\end{array}$ & [78] \\
\hline
\end{tabular}


TABle 6: Continued.

\begin{tabular}{|c|c|c|c|c|c|}
\hline S. N. & IUPAC names & Common names & Structure & $\begin{array}{l}\text { Plant part } \\
\text { (Country) }\end{array}$ & References \\
\hline 140 & $\begin{array}{l}\text { 3,7,11,15-Tetramethyl-2- } \\
\text { hexadecenoic acid }\end{array}$ & Phytanic acid & & $\begin{array}{l}\text { Whole } \\
\text { (Taiwan) }\end{array}$ & {$[78]$} \\
\hline 141 & $\begin{array}{c}\text { 3,7,11,15-Tetramethyl-2- } \\
\text { hexadecenyl ester-heptanoic } \\
\text { acid }\end{array}$ & $\begin{array}{l}\text { Phythyl } \\
\text { heptanoate }\end{array}$ & & $\begin{array}{c}\text { Leaves } \\
\text { (Not stated) }\end{array}$ & {$[60]$} \\
\hline 142 & $\begin{array}{c}(3 S, 10 R, 13 R)-17- \\
((2 R, 5 R)-5 \text {-Ethyl-6- } \\
\text { methylheptan-2-yl)- } \\
2,3,4,7,8,9,10,11,12,13,14,15,16,17- \\
\text { tetradecahydro- } \\
\text { 10,13-dimethyl-1H- } \\
\text { cyclopenta[a]phenanthren- } \\
\text { 3-ol }\end{array}$ & Campestrol & & $\begin{array}{c}\text { Aerial } \\
\text { (Tanzania) }\end{array}$ & [25] \\
\hline 143 & Not found & Phytosterin-B & Not found & $\begin{array}{l}\text { Not found } \\
\text { (Taiwan; } \\
\text { Egypt) }\end{array}$ & {$[66,95]$} \\
\hline 144 & Stigmast-5-en-3-ol & $\beta$-sitosterol & & $\begin{array}{l}\text { Aerial } \\
\text { (Tanzania); } \\
\text { whole } \\
\text { (Taiwan) }\end{array}$ & {$[25,58,78]$} \\
\hline 145 & $\begin{array}{c}\text { 13,14,15,16,17- } \\
\text { Tetradecahydro-10,13- } \\
\text { dimethyl-1H- } \\
\text { cyclopenta[a]phenanthren- } \\
\text { 3-yloxy)-tetrahydro- } \\
\text { 6-(hydroxymethyl)- } \\
\text { 2H-pyran-3,4,5-triol }\end{array}$ & $\begin{array}{l}\beta \text {-Sitosterol } \\
\text { glucoside }\end{array}$ & & $\begin{array}{l}\text { Not found } \\
\text { (Egypt) }\end{array}$ & {$[66]$} \\
\hline 146 & $\begin{array}{l}5 \alpha \text {-Stigmasta-7- } \\
\text { en-3 } \beta \text {-ol }\end{array}$ & & & $\begin{array}{l}\text { Whole } \\
\text { (Taiwan) }\end{array}$ & [78] \\
\hline 147 & $5 \alpha$-Stigmasta-7,22t-dien- $3 \beta$-ol & & & $\begin{array}{l}\text { Whole } \\
\text { (Taiwan) }\end{array}$ & [78] \\
\hline 148 & Stigmasta-5,22-dien-3-ol & Stigmasterol & & $\begin{array}{l}\text { Not found } \\
\text { (Taiwan); } \\
\text { aerial } \\
\text { (Tanzania); } \\
\text { leaves (not } \\
\text { stated); } \\
\text { whole } \\
\text { (Taiwan) }\end{array}$ & $\begin{array}{c}{[25,58,60,} \\
78]\end{array}$ \\
\hline
\end{tabular}


TABLE 6: Continued.

\begin{tabular}{|c|c|c|c|c|c|}
\hline S. N. & IUPAC names & Common names & Structure & $\begin{array}{l}\text { Plant part } \\
\text { (Country) }\end{array}$ & References \\
\hline 149 & Lup-20(29)-en-3-ol & Lupeol & & $\begin{array}{l}\text { Not found } \\
\text { (Egypt) }\end{array}$ & {$[66]$} \\
\hline 150 & Lup-20(29)-en-3-ol, acetate & Lupeol acetate & & $\begin{array}{l}\text { Not found } \\
\text { (Egypt) }\end{array}$ & {$[66]$} \\
\hline 151 & Olean-12-en-3-ol & $\beta$-amyrin & & $\begin{array}{l}\text { Not found } \\
\text { (Egypt) }\end{array}$ & {$[66]$} \\
\hline 152 & $\begin{array}{c}\text { 5,9,13-Trimethyl- } \\
\text { 24,25,26-trinoroleanan-3-ol }\end{array}$ & Friedelan-3 $\beta$-ol & & $\begin{array}{c}\text { Aerial } \\
\text { (Tanzania) }\end{array}$ & {$[25]$} \\
\hline 153 & $\begin{array}{c}\text { 5,9,13-Trimethyl- } \\
\text { 24,25,26-trinoroleanan-3-one }\end{array}$ & $\begin{array}{l}\text { Friedelin; } \\
\text { friedelan-3-one }\end{array}$ & & $\begin{array}{c}\text { Aerial } \\
\text { (Tanzania) }\end{array}$ & {$[25]$} \\
\hline 154 & $\begin{array}{c}2,6,10,15,19,23- \\
\text { Hexamethyl-2,6,10,14,18,22- } \\
\text { tetracosahexaene }\end{array}$ & Squalene & & $\begin{array}{c}\text { Aerial } \\
\text { (Tanzania); } \\
\text { Leaves (Not } \\
\text { stated); } \\
\text { Whole } \\
\text { (Taiwan) }\end{array}$ & {$[25,60,78]$} \\
\hline 155 & $\beta, \beta$-Carotene & $\beta$-Carotene & & $\begin{array}{l}\text { Leaves (Not } \\
\text { stated) }\end{array}$ & {$[96]$} \\
\hline
\end{tabular}




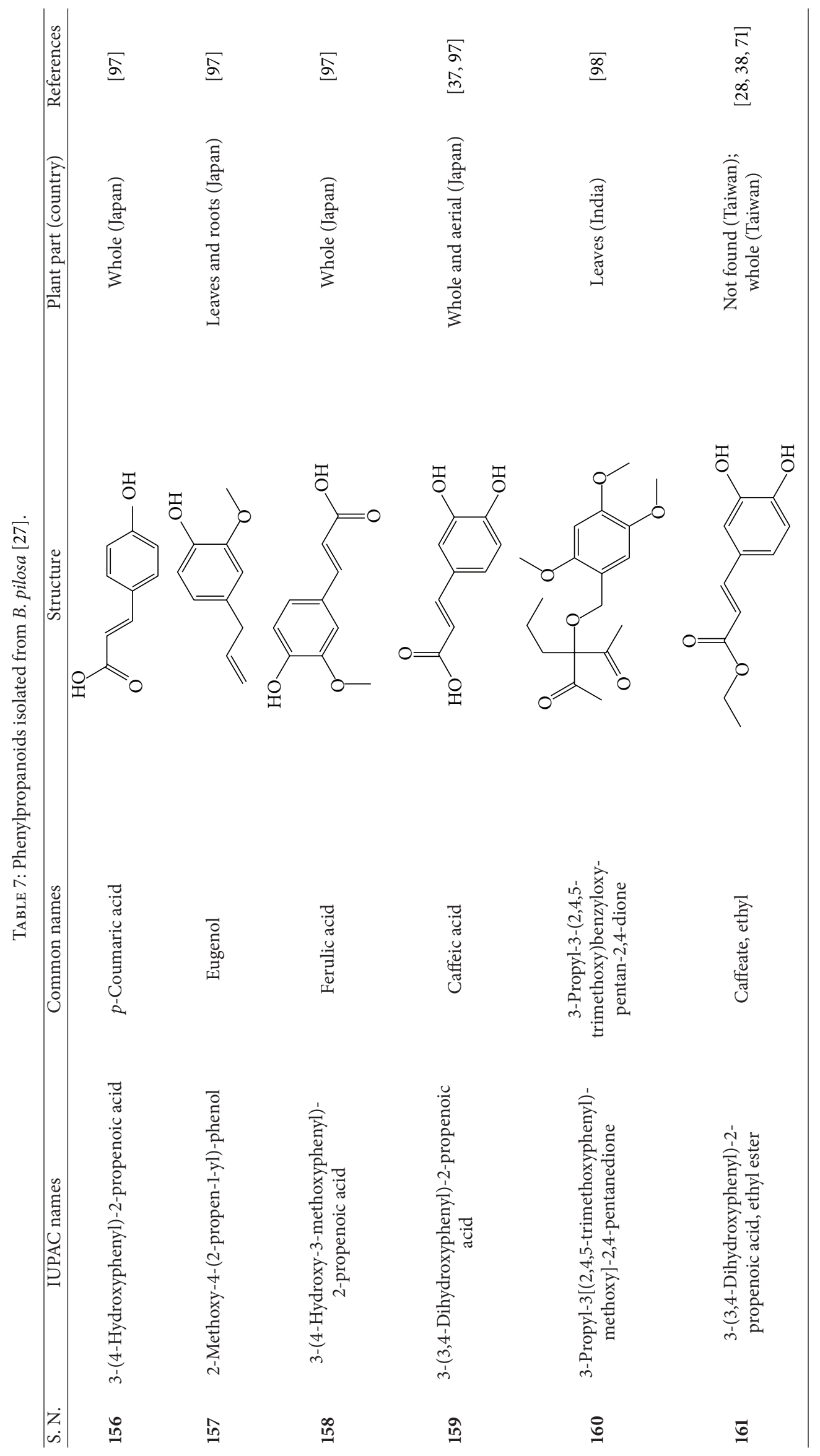




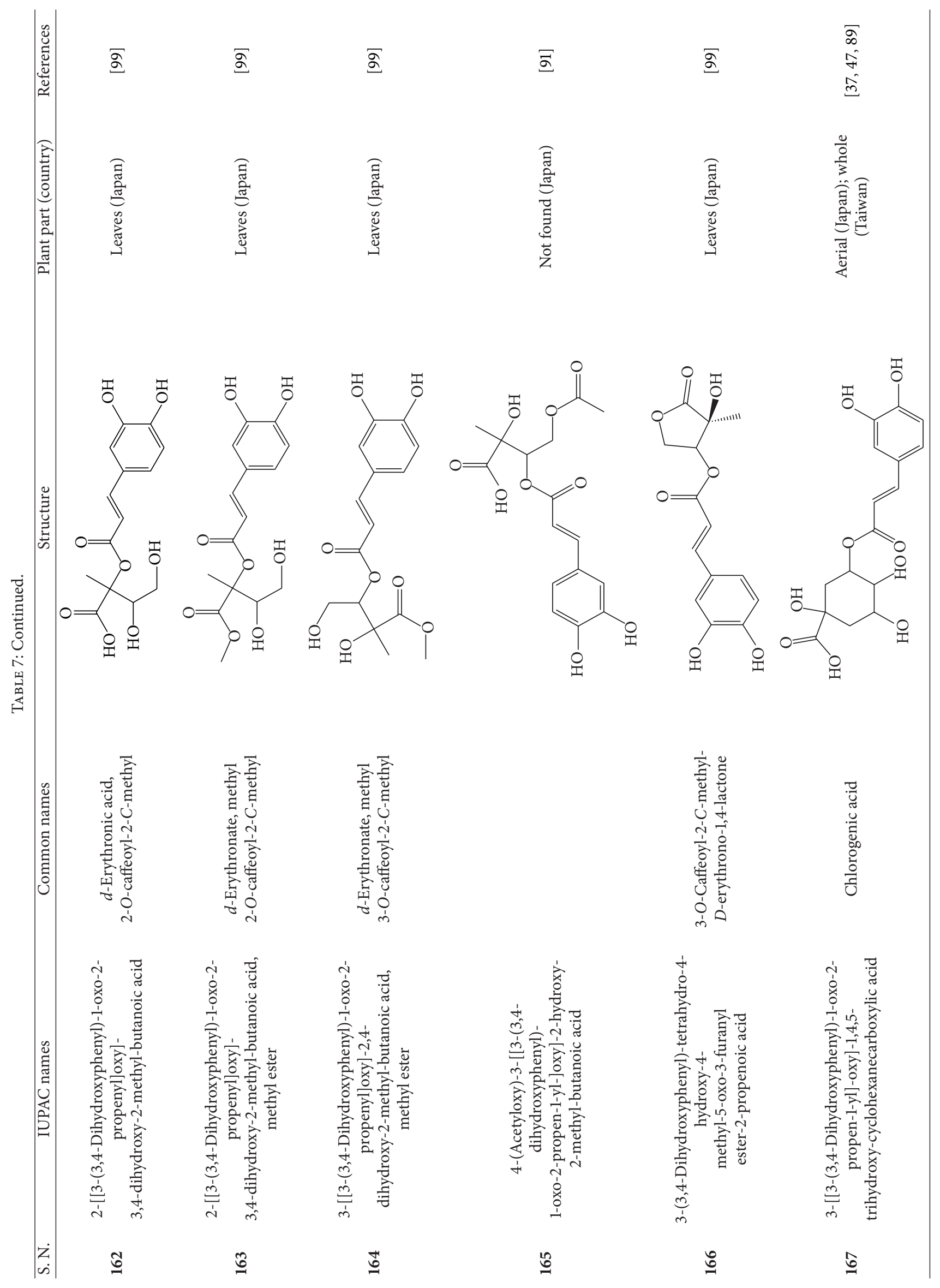









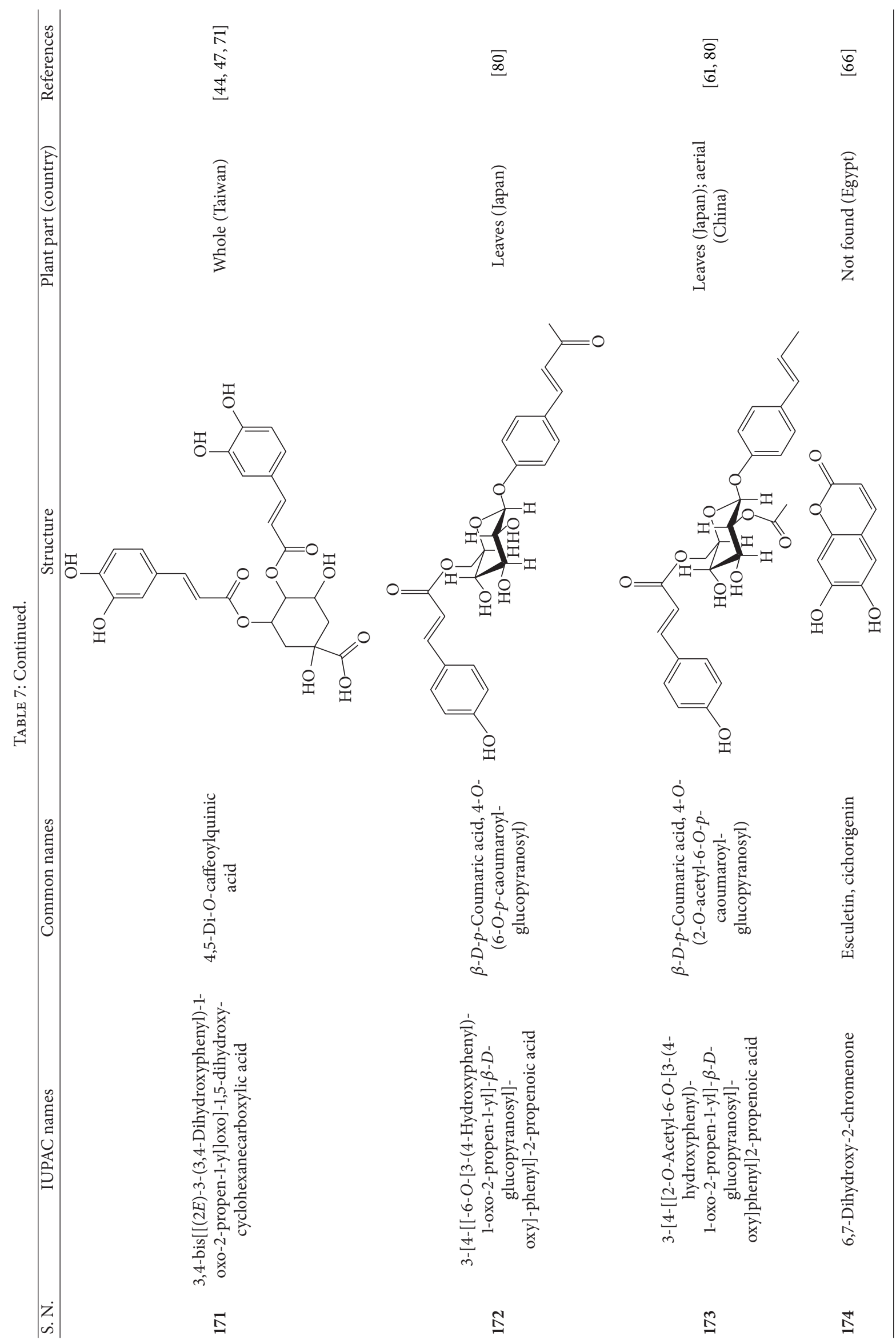


TABLE 8: Aromatic compounds isolated from B. pilosa [27].

\begin{tabular}{|c|c|c|c|c|c|}
\hline S. N. & IUPAC names & Common names & Structure & $\begin{array}{l}\text { Plant part } \\
\text { (country) }\end{array}$ & References \\
\hline 175 & 1,2-Benzenediol & Pyrocatechin & & $\begin{array}{l}\text { Whole } \\
\text { (Japan) }\end{array}$ & {$[97]$} \\
\hline 176 & 4-Ethyl-1,2-benzenediol & Pyrocatechol & & $\begin{array}{l}\text { Whole } \\
\text { (Japan) }\end{array}$ & [97] \\
\hline 177 & $\begin{array}{c}\text { Dimethoxyphenol; } \\
\text { 2,6-dimethoxyphenol }\end{array}$ & & & Roots (Japan) & {$[97]$} \\
\hline 178 & $\begin{array}{l}\text { 4-Ethenyl-2-methoxy- } \\
\text { phenol }\end{array}$ & $p$-Vinylguaiacol & & $\begin{array}{l}\text { Whole } \\
\text { (Japan) }\end{array}$ & {$[97]$} \\
\hline 179 & $\begin{array}{l}\text { 2-Hydroxy-6- } \\
\text { methylbenzaldehyde }\end{array}$ & $\begin{array}{l}\text { 6-Methyl- } \\
\text { salicylaldehyde }\end{array}$ & & $\begin{array}{l}\text { Whole } \\
\text { (Japan) }\end{array}$ & [97] \\
\hline 180 & Benzene-ethanol & 2-Phenyl-ethanol & & $\begin{array}{l}\text { Whole } \\
\text { (Japan) }\end{array}$ & {$[78]$} \\
\hline 181 & $\begin{array}{l}\text { 4-Hydroxy-3-methoxy- } \\
\text { benzaldehyde }\end{array}$ & Vanillin & & $\begin{array}{c}\text { Aerial } \\
\text { (Japan) }\end{array}$ & [97] \\
\hline 182 & $\begin{array}{l}\text { 3-Hydroxy-4-methoxy- } \\
\text { benzaldehyde }\end{array}$ & Vanillin, iso & & $\begin{array}{l}\text { Leaves } \\
\text { (Japan) }\end{array}$ & [97] \\
\hline 183 & 4-Hydroxybenzoic acid & $\begin{array}{l}p \text {-Hydroxybenzoic } \\
\text { acid }\end{array}$ & & $\begin{array}{l}\text { Whole } \\
\text { (Japan) }\end{array}$ & {$[97]$} \\
\hline 184 & 2-Hydroxybenzoic acid & Salicylic acid & & $\begin{array}{c}\text { Stem and } \\
\text { roots (Japan) }\end{array}$ & {$[97]$} \\
\hline 185 & $\begin{array}{l}\text { 3,4-Dihydroxybenzoic } \\
\text { acid }\end{array}$ & Protocatechuic acid & & $\begin{array}{l}\text { Whole } \\
\text { (Japan) }\end{array}$ & {$[97]$} \\
\hline 186 & $\begin{array}{l}\text { 4-Hydroxy- } \\
\text { 3methoxybenzoic } \\
\text { acid }\end{array}$ & Vanillic acid & & $\begin{array}{c}\text { Aerial } \\
\text { (Uganda); } \\
\text { Roots (Japan) }\end{array}$ & {$[88,97]$} \\
\hline
\end{tabular}


TABLE 8: Continued.

\begin{tabular}{|c|c|c|c|c|c|}
\hline S. N. & IUPAC names & Common names & Structure & $\begin{array}{l}\text { Plant part } \\
\text { (country) }\end{array}$ & References \\
\hline 187 & $\begin{array}{l}\text { 3,4,5-Trihydroxybenzoic } \\
\text { acid }\end{array}$ & Gallic acid & & $\begin{array}{l}\text { Whole } \\
\text { (China) }\end{array}$ & [100] \\
\hline
\end{tabular}

of 50 to $200 \mathrm{ppm}$ [31] and prevent skin cancer [31] and cancer invasion [102]. Lee and colleagues reported that luteolin prevents cancer by inhibiting cell adhesion and invasion [102]. Significant inhibition concentration was reported to be $5 \mu \mathrm{M}$ and complete inhibition concentration was reported to be $40 \mu \mathrm{M}$. Moreover, luteolin was reported to inhibit hepatocyte growth factor (HGF)-induced cell scattering as well as cytoskeleton changes such as filopodia and lamellipodia which was determined using phase-contrast and fluorescence microscopy. Furthermore, luteolin also inhibited the HGFinduced phosphorylation of c-Met, ERK 1/2, and Akt as well as the MAPK/ERK and P13 K-Akt pathways [31, 102]. Other mechanisms underlying the anticancer activities of luteolin are the inhibition of topoisomerase I and II, which inhibits cell replication and DNA repair thus promoting apoptosis, regulation of PI-3-Kinase/Akt/MAPK/ERK/JNK, activation of apoptosis in the mitochondrial pathway by activating caspase 9 and caspase 3, which were found in malignant cells but not in normal human peripheral blood mononuclear cells, death receptor-induced apoptosis, and a cell-cycle arrest mechanism, inhibition of fatty acid synthase which is upregulated in many cancer cells, and sensitization to chemotherapy whereby luteolin increases the susceptibility of cancer cells to chemotherapy [31]. Butein (82) is another flavonoid that showed a cytotoxic effect on human colon adenocarcinoma cell proliferation with a reported $\mathrm{IC}_{50}$ value of $1.75 \mu \mathrm{M}$. Butein at $2 \mu \mathrm{M}$ affected the incorporation of $\left[{ }^{14} \mathrm{C}\right]-$ labeled leucine, thymidine, and uridine which can cause the inhibition of DNA, RNA, and protein synthesis of human colon cancer cells. Moreover, butein also exhibited noncompetitive inhibition of 1-chloro-2,4-dinitrobenzene (CDNB) in glutathione S-transferase (GST) activity. Tumor resistance was correlated with high levels of GST, thus, butein inhibited proliferation of cancer cells [33]. Another flavonoid present in $B$. pilosa, centaureidin (109), also showed anti-cancer activity in B lymphoma cells. Centaureidin, isolated from Polymnia fruticosa, inhibited tubulin polymerization in vitro and induced mitotic figure formation in CA46 Burkitt lymphoma cells. Using turbidimetric assay, the $\mathrm{IC}_{50}$ value of centaureidin in inhibition of mitosis was $3 \mu \mathrm{M}$ [103]. Cytotoxicity of centaureidin was further analyzed using American National Cancer Institute (NCI) 60 human tumor cell lines. The cytotoxicity potency of centaureidin, expressed as $\mathrm{GI}_{50}(50 \%$ growth inhibition in the NCI tumor line panel), was $0.24 \mu \mathrm{M}$ [34]. These data mark centaureidin as a promising antimitotic agent for tumor therapy.

In addition to anti-tumor flavones, polyynes found in $B$. pilosa have also been shown to possess anti-tumor properties.
Based on a bioactivity-directed isolation approach, $\mathrm{Wu}$ and colleagues identified two polyyne aglycones from the ethyl acetate fraction of $B$. pilosa [70]. 1,2-Dihydroxytrideca5,7,9,11-tetrayne (48) and 1,3-Dihydroxy-6(E)-tetradecene8,10,12-triyne (46) exhibited significant anticell proliferation activity in primary human umbilical vein endothelium cells (HUVEC) with $\mathrm{IC}_{50}$ values of $12.5 \mu \mathrm{M}$ and $1.73 \mu \mathrm{M}$, respectively. They also decreased angiogenesis and promoted apoptosis in human endothelial cells. Their anti-angiogenic and cytotoxic effects correlated with activation of the CDK inhibitors and caspase-7 [70]. In addition, 1,2-Dihyroxy-5(E)tridecene-7,9,11-triyne (45) showed antiangiogenic effects in HUVECs with an $\mathrm{IC}_{50}$ value of $12.4 \mu \mathrm{M}$ as evidenced by a decrease in the tube formation and migration of HUVECs [28]. The $\mathrm{IC}_{50}$ value of compound 45 in the inhibition of basic fibroblast growth factor-induced HUVEC growth was $28.2 \mu \mathrm{M}$. However, it had higher $\mathrm{IC}_{50}$ values than those for lung carcinoma cells and keratinocytes. This compound could also inhibit cell proliferation of HUVECs, lung carcinoma A549 cells and HACAT keratinocytes. The mechanism by which compound 45 inhibits HUVEC growth and angiogenesis is complicated and includes decreasing the expression of cell cycle regulators (CDK4, cyclins D1 and A, retinoblastoma $(\mathrm{Rb})$, and vascular endothelial growth factor receptor 1), caspase-mediated activation of CDK inhibitors p21 (Cip1) and p27 (Kip), upregulation of Fas ligand expression, downregulation of Bcl-2 expression, and activation of caspase-7 and poly (ADP-ribose) polymerase [28].

3.2. Anti-Inflammatory Activity. B. pilosa is commonly used to treat inflammatory disorders. The anti-inflammatory phytochemicals present in B. pilosa are listed in Table 11. Cyclooxygenase-2 (COX-2) is a physiologically important enzyme that converts arachidonic acid to prostaglandin $\left(\mathrm{PGE}_{2}\right)$. Its expression is induced by a wide variety of external stimuli indicating its involvement in inflammatory diseases, and it is used as an inflammatory marker [42]. Yoshida and colleagues studied the effects of the aqueous extracts of B. pilosa aerial parts in the production of COX-2 and $\mathrm{PGE}_{2}$ as well as on the activation of mitogen activated protein kinases (MAPKs) in normal human dermal fibroblasts (HDFs) in response to inflammatory cytokine, IL- $1 \beta$. This work showed that IL- $1 \beta$ activated MAPKs such as ERK1/2, p38, and JNK to different extents and induced COX-2 expression. The COX-2 expression in HDFs was regulated mainly by $\mathrm{p} 38$ following IL-1 $\beta$ stimulation. Consistently, the p38 inhibitor SB203580 blocked this expression. Using this cell platform, $B$. pilosa extracts were tested for inhibition of inflammation. 
TABle 9: Porphyrins isolated from B. pilosa [27].

\begin{tabular}{|c|c|c|c|c|c|}
\hline S. N. & IUPAC names & Common names & Structure & $\begin{array}{l}\text { Plant part } \\
\text { (country) }\end{array}$ & References \\
\hline 188 & $\begin{array}{c}(2 E, 7 R, 11 R)-3,7,11,15- \\
\text { Tetramethyl-2-hexadecen-1-yl } \\
\text { ester-(15S,16S)-10-ethenyl-5- } \\
\text { ethyl-1,16,18,20-tetrahydro- } \\
\text { 6,11,15,22-tetramethyl-18,20- } \\
\text { dioxo-15H-9,12-imino-21,2- } \\
\text { metheno-4,7:17,14- } \\
\text { dinitrilopyrano[4,3- } \\
\text { b]azacyclononadecine-16- } \\
\text { propanoic } \\
\text { acid }\end{array}$ & AristophyllC & & $\begin{array}{l}\text { Leaves } \\
\text { (Taiwan) }\end{array}$ & {$[98]$} \\
\hline 189 & $\begin{array}{c}(2 E, 7 R, 11 R)-3,7,11,15- \\
\text { Tetramethyl-2-hexadecen-1-yl } \\
\text { ester- }(2 S, 18 S, 19 S, 20 \mathrm{~b} R)-13- \\
\text { ethenyl-8-ethyl- } \\
\text { 2a,18,19,20b-tetrahydro-20b- } \\
\text { (methoxycarbonyl)-9,14,18,24- } \\
\text { tetramethyl-4H-12,15-imino-3,5- } \\
\text { metheno-7,10:20,17-dinitrilo-1,2- } \\
\left.\text { dioxeto-[3' } 3^{\prime}: 3,4\right] \text {-cyclo- } \\
\text { pent[1, 2]azacyclononadecine- } \\
\text { 19-propanoic acid }\end{array}$ & Bidenphytin A & & $\begin{array}{l}\text { Leaves } \\
\text { (Taiwan) }\end{array}$ & {$[98]$} \\
\hline 190 & $\begin{array}{c}(2 E, 7 R, 11 R)-3,7,11,15- \\
\text { Tetramethyl-2-hexadecen-1-yl } \\
\text { ester- }(2 S, 18 S, 19 S, 20 \mathrm{~b} R)-13- \\
\text { ethenyl-8-ethyl- } \\
\text { 2a,18,19,20b-tetrahydro-2a- } \\
\text { hydroxy-20b- } \\
\text { (methoxycarbonyl)- } \\
\text { 9,14,18,24-tetramethyl-4H-12,15- } \\
\text { imino-3,5-metheno-7,10:20,17- } \\
\text { dinitrilo-1,2- } \\
\left.\text { dioxeto[3', } 4^{\prime}: 3,4\right]- \\
\text { cyclo-pent }[1,2-\mathrm{b}]- \\
\text { azacyclononadecine- } \\
\text { 19-propanoic acid }\end{array}$ & Bidenphytin B & & $\begin{array}{l}\text { Leaves } \\
\text { (Taiwan) }\end{array}$ & {$[98]$} \\
\hline 191 & $\begin{array}{c}(2 E, 7 R, 11 R)-3,7,11,15- \\
\text { Tetramethyl-2-hexadecen-1-yl } \\
\text { ester-(3R,4S,21R)-14-ethyl-21- } \\
\text { hydroxy-21-(methoxycarbonyl)- } \\
\text { 4,8,9,13,18-pentamethyl-20-oxo- } \\
\text { 3-phorbinepropanoic acid }\end{array}$ & $\begin{array}{l}\left(13^{2} R\right)-13^{2}- \\
\text { Hydroxypheophytin A }\end{array}$ & & $\begin{array}{l}\text { Leaves } \\
\text { (Taiwan) }\end{array}$ & [98] \\
\hline 192 & $\begin{array}{l}(2 E, 7 R, 11 R)-3,7,11,15- \\
\text { Tetramethyl-2-hexadecen-1-yl } \\
\text { ester-(3R,4S,21S)-14-ethyl-21- } \\
\text { hydroxy-21-(methoxycarbonyl)- } \\
\text { 4,8,9,13,18-pentamethyl-20-oxo- } \\
\text { 3-phorbinepropanoic acid }\end{array}$ & $\begin{array}{c}\left(13^{2} S\right)-13^{2}- \\
\text { Hydroxypheophytin A }\end{array}$ & & $\begin{array}{l}\text { Leaves } \\
\text { (Taiwan) }\end{array}$ & [98] \\
\hline
\end{tabular}


TABLe 9: Continued.

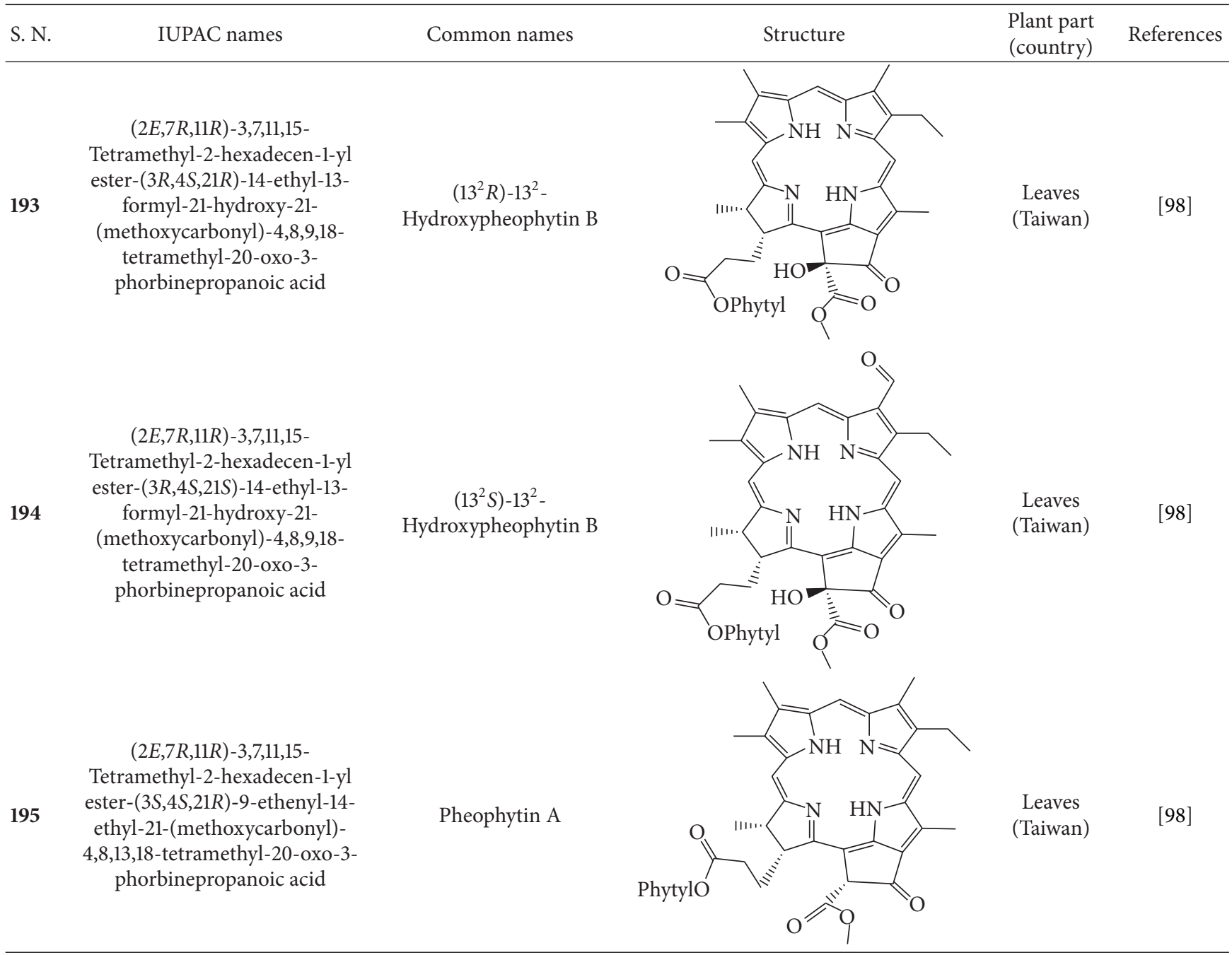

The extract dose-dependently suppressed the activation of p38 and JNK and moderately suppressed ERK1/2, as well as suppressing COX-2 expression and $\mathrm{PGE}_{2}$ production [42]. This work supports the use of B. pilosa as an antiinflammatory agent; however, no compounds responsible for the anti-inflammatory activity of $B$. pilosa were identified.

A further study also reported the anti-inflammatory activity as well as the antiallergic activity of B. pilosa [37]. In this study, dried powder of the aerial part of B. pilosa, which had been pretreated with the enzyme cellulosine, was used for further tests. The results showed that oral administration of the cellulosine-treated B. pilosa lowered the level of serum IgE in mice 10 days after immunization with DNP $(2,4-$ dintrophenyl)-Ascaris as an antigen. This treatment also reduced dye exudation in skin induced by passive cutaneous anaphylaxis and production of inflammatory mediators, histamine, and substance $P$ in rats [37]. Phytochemical analysis showed that cellulosine treatment increased the percentage of caffeic acid and flavonoids. This study suggests that B. pilosa and its phenolics have anti-inflammatory functions.

Phenolics and polyynes are major anti-inflammatory phytochemicals present in B. pilosa (Table 11).Unsurprisingly, phenolics such as luteolin (103) and ethyl caffeate (161) that are major constituents of $B$. pilosa have also been reported to possess anti-inflammatory activity. Luteolin was reported to exhibit anti-inflammatory activity in macrophages. Xagorari and colleagues showed that luteolin inhibited the release of inflammatory cytokines, TNF- $\alpha$ and interleukin-6, in RAW 264.7 cells following LPS stimulation [41]. It inhibited TNF- $\alpha$ production with an $\mathrm{IC}_{50}$ value of $1 \mu \mathrm{M}$. The underlying antiinflammatory mechanism of luteolin was reported to be the inactivation of Akt and NF- $\kappa \mathrm{B}$ activation [41]. In addition, luteolin was reported to confer anti-inflammatory activity through inhibition of LPS-stimulated iNOS expression in BV-2 microglial cells. It inhibited LPS-activated microglia in a dose-dependent manner with an $\mathrm{IC}_{50}$ value of $6.9 \mu \mathrm{M}$. Moreover, immunoblot and RT-PCR data proved that luteolin suppressed $\mathrm{I} \kappa \mathrm{B}-\alpha$ degradation and iNOS expression in LPS-activated microglia [39]. Kim and colleagues stated that luteolin may have beneficial effects on inflammatory neural diseases through inhibition of iNOS expression [39]. A related study revealed that luteolin decreased the transcriptional activity of NF- $\kappa$ B RelA via partial inhibition of TNF-mediated NF- $\kappa$ B DNA binding activity. Luteolin also 
TABLE 10: Other compounds isolated from B. pilosa [27].

\begin{tabular}{|c|c|c|c|c|c|}
\hline S.N. & IUPAC names & Common names & Structure & $\begin{array}{l}\text { Plant part } \\
\text { (country) }\end{array}$ & References \\
\hline 196 & $\begin{array}{c}\text { 3,7-Dihydro-1,3,7- } \\
\text { trimethyl-1H-purine- } \\
\text { 2,6-dione }\end{array}$ & Caffeine & & $\begin{array}{c}\text { Aerial } \\
\text { (Uganda) }\end{array}$ & {$[88]$} \\
\hline 197 & $\begin{array}{c}\text { 1- }((2 R, 4 S, 5 R)- \\
\text { Tetrahydro-4-hydroxy- } \\
\text { 5-(hydroxymethyl) } \\
\text { furan-2-yl)-5- } \\
\text { methylpyrimidine- } \\
\text { 2,4(1H,3H)-dione }\end{array}$ & Thymidine & & $\begin{array}{l}\text { Not found } \\
\text { (China) }\end{array}$ & {$[64]$} \\
\hline 198 & 1-(2-Thienyl)-ethanone & 2-Acetyl-thiophene & & $\begin{array}{c}\text { Roots } \\
\text { (Germany) }\end{array}$ & {$[68]$} \\
\hline 199 & $\begin{array}{c}(2 R, 3 S, 4 S, 5 S)-2- \\
\text { (Heptan-2-yloxy)- } \\
\text { tetrahydro-6- } \\
\text { ((tetrahydro-3,4- } \\
\text { dihydroxy-5- } \\
\text { (hydroxymethyl)furan- } \\
\text { 2-yloxy)methyl)- } \\
\text { 2H-pyran-3,4,5-triol }\end{array}$ & $\begin{array}{c}\text { Heptanyl } \\
2-O-\beta \text {-xylofuranosyl- } \\
(1 \rightarrow 6)-\beta \text { - } \\
\text { glucopyranoside }\end{array}$ & I & $\begin{array}{l}\text { Whole } \\
\text { (Taiwan) }\end{array}$ & {$[47]$} \\
\hline 200 & $\begin{array}{c}\text { 2-[(3R,7R,11R)-3- } \\
\text { Hydroxy-3,7,11,15- } \\
\text { tetramethylhexadecyl]- } \\
\text { 3,5,6-trimethyl- } \\
\text { 2,5-cyclohexadiene-1,4- } \\
\text { dione }\end{array}$ & $\begin{array}{c}\alpha \text {-Tocopheryl } \\
\text { quinone }\end{array}$ & & $\begin{array}{l}\text { Whole } \\
\text { (Taiwan) }\end{array}$ & [59] \\
\hline 201 & & $\begin{array}{c}\text { 7-O- }\left(4^{\prime \prime}, 6^{\prime \prime}-\text { Diacetyl }\right)- \\
\beta-D- \\
\text { glucopyranoside }\end{array}$ & Not found & $\begin{array}{l}\text { Leaves } \\
\text { (China) }\end{array}$ & {$[81]$} \\
\hline
\end{tabular}

inhibited Akt phosphorylation and induced degradation of a transcription factor, interferon regulatory factor (IRF) [40].

Chiang and colleagues showed that ethyl caffeate (161) significantly inhibited NO production in mouse macrophages, RAW 264.7 cells [38]. Based on MTT assays, they concluded that this inhibition was not due to the cytotoxicity of ethyl caffeate. The $\mathrm{IC}_{50}$ value of ethyl caffeate in the inhibition of NO production was $5.5 \mu \mathrm{g} / \mathrm{mL}$, slightly lower than curcumin (positive control) which has an $\mathrm{IC}_{50}$ value of $6.5 \mu \mathrm{g} / \mathrm{mL}$. They demonstrated that ethyl caffeate exerted anti-inflammatory activity via the reduced transcription and translation of iNOS (inducible nitric oxide synthase) in RAW 246.7 cells. In addition, this compound also suppressed COX-2 expression in RAW 246.7 cells and MCF-7 cells. The in vivo anti-inflammatory effect of ethyl caffeate was verified by testing in TPA-treated mouse skin. Like celecoxib, the positive control, ethyl caffeate significantly abolished COX-2 expression in a dose-dependent manner. Ethyl caffeate at $1 \mathrm{mg} / 200 \mu \mathrm{L} /$ site (24 mM) inhibited COX-2 expression at a level comparable to celecoxib at $1 \mathrm{mg} / 200 \mu \mathrm{L} /$ site $(13 \mathrm{mM})$. Remarkably, ethyl caffeate at $48 \mathrm{mM}(2 \mathrm{mg} / 200 \mu \mathrm{L} / \mathrm{site})$ was more effective than celecoxib at $131 \mathrm{mM}(10 \mathrm{mg} / 200 \mu \mathrm{L} /$ site $)$. Moreover, this compound inhibited the activation of nuclear factor $-\kappa \mathrm{B}$ $(\mathrm{NF}-\kappa \mathrm{B})$ by LPS via the prevention of NF- $\kappa \mathrm{B}$ binding to DNA [38]. In addition, 3 ethyl caffeate analogs (ethyl 3,4dihydroxyhydrocinnamate, ethyl cinnamate, and catechol) also showed different degrees of NF- $\kappa \mathrm{B}$ binding to DNA as 
TABLE 11: Chemical constituents of B. pilos $a$ and their biological activities.

\begin{tabular}{|c|c|c|c|c|}
\hline S.N. & Name & Classification & $\begin{array}{c}\text { Molecular } \\
\text { formula }\end{array}$ & Biological activities \\
\hline 109 & Centaureidin [52] & Flavonoid & $\mathrm{C}_{18} \mathrm{H}_{16} \mathrm{O}_{8}$ & $\begin{array}{l}\text { Anti-listerial }[29,52] \\
\text { Cytotoxic }[9]\end{array}$ \\
\hline 110 & Centaurein [52] & Flavonoid & $\mathrm{C}_{24} \mathrm{H}_{26} \mathrm{O}_{13}$ & $\begin{array}{c}\text { Anti-listerial }[29,52] \\
\text { Cytotoxic }[9] \\
\text { Anti-viral }[104]\end{array}$ \\
\hline 103 & Luteolin [105] & Flavonoid & $\mathrm{C}_{15} \mathrm{H}_{10} \mathrm{O}_{6}$ & $\begin{array}{c}\text { Anti-viral }[106,107] \\
\text { Cytotoxic }[30] \\
\text { Anti-inflammatory }[108] \\
\text { Anti-allergic }[108]\end{array}$ \\
\hline 82 & Butein [109] & Flavonoid & $\mathrm{C}_{15} \mathrm{H}_{12} \mathrm{O}_{5}$ & $\begin{array}{l}\text { Anti-leishmanial [110] } \\
\quad \text { Cytotoxic [31] }\end{array}$ \\
\hline 48 & 1,2-Dihydroxytrideca-5,7,9,11-tetrayne [111] & Polyyne & $\mathrm{C}_{13} \mathrm{H}_{12} \mathrm{O}_{2}$ & Anti-angiogeneic [111] \\
\hline 46 & 1,3-Dihyroxy-6(E)-tetradecene-8,10,12-triyne [111] & Polyyne & $\mathrm{C}_{14} \mathrm{H}_{16} \mathrm{O}_{2}$ & Anti-angiogeneic [111] \\
\hline 45 & 1,2-Dihyroxy-5(E)-tridecene-7,9,11-triyne [112] & Polyyne & $\mathrm{C}_{13} \mathrm{H}_{14} \mathrm{O}_{2}$ & $\begin{array}{l}\text { Anti-angiogeneic [112] } \\
\text { Anti-proliferative [112] }\end{array}$ \\
\hline 64 & 1-Phenylhepta-1,3,5-triyne [113] & Polyyne & $\mathrm{C}_{13} \mathrm{H}_{8}$ & $\begin{array}{c}\text { Anti-microbial [114] } \\
\text { Anti-malarial [3] } \\
\text { Cytotoxic [3] } \\
\text { Antifungal [14] }\end{array}$ \\
\hline 27 & Linoleic acid [32] & Fatty acid & $\mathrm{C}_{18} \mathrm{H}_{32} \mathrm{O}_{2}$ & $\begin{array}{l}\text { Anti-viral (100) } \\
\text { Cytotoxic [23] }\end{array}$ \\
\hline 161 & Ethyl caffeate [38] & Phenylpropanoid & $\mathrm{C}_{11} \mathrm{H}_{12} \mathrm{O}_{4}$ & Anti-inflammatory [38] \\
\hline 54 & 2-O- $\beta$-Glucosyltrideca-11(E)-en-3,5,7,9-tetrayn-1,2-diol [17] & Polyyne & $\mathrm{C}_{19} \mathrm{H}_{20} \mathrm{O}_{7}$ & $\begin{array}{l}\text { Immunosuppressive and } \\
\text { Anti-inflammatory [17] }\end{array}$ \\
\hline 53 & 2- $\beta$-D-Glucopyranosyloxy-1-hydroxytrideca-5,7,9,11-tetrayne [50] & Polyyne & $\mathrm{C}_{19} \mathrm{H}_{22} \mathrm{O}_{7}$ & $\begin{array}{c}\text { Anti-diabetic [115] } \\
\text { Anti-inflammatory [50] }\end{array}$ \\
\hline 69 & 3- $\beta$-D-Glucopyranosyl-1-hydroxy-6(E)-tetradecene-8,10,12-triyne [19] & Polyyne & $\mathrm{C}_{20} \mathrm{H}_{26} \mathrm{O}_{7}$ & $\begin{array}{l}\text { Anti-diabetic [19] } \\
\text { Anti-inflammatory [55] }\end{array}$ \\
\hline 50 & 2- $\beta$-D-Glucopyranosyloxy-1-hydroxy-5(E)-tridecene-7,9,11-triyne [19] & Polyyne & $\mathrm{C}_{19} \mathrm{H}_{24} \mathrm{O}_{7}$ & $\begin{array}{c}\text { Anti-diabetic [19] } \\
\text { Anti-inflammatory [55] } \\
\text { Anti-malarial and } \\
\text { antibacterial [51] }\end{array}$ \\
\hline 129 & Quercetin 3-O- $\beta$ - $D$-galactopyranoside [25] & Flavonoid & $\mathrm{C}_{21} \mathrm{H}_{20} \mathrm{O}_{12}$ & Anti-inflammatory [116] \\
\hline 170 & 3,5-Di-O-caffeoylquinic acid [55] & Phenylpropanoid & $\mathrm{C}_{25} \mathrm{H}_{24} \mathrm{O}_{12}$ & $\begin{array}{l}\text { Anti-viral [78] } \\
\text { Antioxidant [47] }\end{array}$ \\
\hline 171 & 4,5-Di-O-caffeoylquinic acid [55] & Phenylpropanoid & $\mathrm{C}_{25} \mathrm{H}_{24} \mathrm{O}_{12}$ & $\begin{array}{l}\text { Anti-viral [78] } \\
\text { Antioxidant [47] }\end{array}$ \\
\hline 169 & 3,4-Di-O-caffeoylquinic acid [55] & Phenylpropanoid & $\mathrm{C}_{25} \mathrm{H}_{24} \mathrm{O}_{12}$ & $\begin{array}{l}\text { Anti-viral [78] } \\
\text { Antioxidant [47] }\end{array}$ \\
\hline 126 & $\begin{array}{l}\text { Quercetin 3,3'-dimethyl ether } \\
\text { 7-O- } \alpha \text { - } L \text {-rhamnopyranosyl- }(1 \rightarrow 6)-\beta-D \text {-glucopyranoside [117] }\end{array}$ & Flavonoid & $\mathrm{C}_{21} \mathrm{H}_{20} \mathrm{O}_{11}$ & Anti-malarial [118] \\
\hline 125 & Quercetin 3,3'-dimethyl ether-7-O- $\beta$ - $D$-glucopyranoside [117] & Flavonoid & $\mathrm{C}_{21} \mathrm{H}_{20} \mathrm{O}_{12}$ & Anti-malarial [118] \\
\hline 70 & 1-Phenyl-1,3-diyn-5-en-7-ol-acetate [18] & Polyyne & $\mathrm{C}_{15} \mathrm{H}_{12} \mathrm{O}_{2}$ & Anti-malarial $[18]$ \\
\hline 199 & Heptanyl 2-O- $\beta$-xylofuranosyl- $(1 \rightarrow 6)-\beta$-glucopyranoside [47] & Miscellaneous & $\mathrm{C}_{18} \mathrm{H}_{44} \mathrm{O}_{10}$ & Antioxidant [47] \\
\hline 124 & 3-O-Rabinobioside [47] & Saccharide & $\mathrm{C}_{27} \mathrm{H}_{38} \mathrm{O}_{15}$ & Antioxidant [47] \\
\hline 130 & Quercetin 3-O-rutinoside [47] & Flavonoid & $\mathrm{C}_{27} \mathrm{H}_{38} \mathrm{O}_{15}$ & Antioxidant [47] \\
\hline 167 & Chlorogenic acid [47] & Phenolic & $\mathrm{C}_{16} \mathrm{H}_{26} \mathrm{O}_{9}$ & Antioxidant [47] \\
\hline 119 & Jacein [47] & Flavonoid & $\mathrm{C}_{24} \mathrm{H}_{26} \mathrm{O}_{13}$ & Antioxidant [47] \\
\hline 49 & $(R)$-1,2-dihydroxytrideca-3,5,7,9,11-pentayne $[51]$ & Polyyne & $\mathrm{C}_{13} \mathrm{H}_{8} \mathrm{O}_{2}$ & $\begin{array}{l}\text { Anti-malarial and } \\
\text { Antibacterial [51] }\end{array}$ \\
\hline
\end{tabular}


listed in Table 12. Ethyl cinnamate lacks a catechol moiety which results in ineffective inhibition of NF- $\kappa \mathrm{B}$ binding to DNA [38].

Pereira and colleagues assessed the anti-inflammatory and immunomodulatory activities of $B$. pilosa methanol extract as well as one polyyne, 2-O- $\beta$-glucosyltrideca-11(E)en-3,5,7,9-tetrayn-1,2-diol (54) in $\mathrm{T}$ lymphocytes and a zymosan-induced arthritis mouse model [18]. They first examined the in vitro effect of the B. pilosa extract and compound 54 on cell proliferation of human T cells stimulated with $5 \mu \mathrm{g} / \mathrm{mL}$ phytohemagglutinin (PHA) or $100 \mathrm{nM}$ 12-O-tetradecanoyl phorbol-13-acetate (TPA) plus $15 \mu \mathrm{M}$ ionomycin and on cell proliferation of mouse $\mathrm{T}$ cells stimulated with $5 \mu \mathrm{g} / \mathrm{mL}$ concanavalin A (Con A). The data demonstrated that both methanol extract and compound $\mathbf{5 4}$ suppressed T-cell proliferation in a dose-dependent manner. The estimated $\mathrm{IC}_{50}$ values of the $B$. pilosa extract against human $\mathrm{T}$ cells stimulated with $5 \mu \mathrm{g} / \mathrm{mL}$ PHA and $100 \mathrm{nM}$ TPA plus $15 \mu \mathrm{M}$ ionomycin were 12.5 and $25 \mu \mathrm{g} / \mathrm{mL}$, respectively. In comparison with the methanol extract, compound $\mathbf{5 4}$ showed 10-fold more inhibition of human T-cell proliferation with an estimated $\mathrm{IC}_{50}$ value of $1.5 \mu \mathrm{g} / \mathrm{mL}$. Accordingly, the B. pilosa extract and compound $\mathbf{5 4}$ dose-dependently suppressed mouse $\mathrm{T}$-cell proliferation with estimated $\mathrm{IC}_{50}$ values of 30 and $2.5 \mu \mathrm{g} / \mathrm{mL}$, respectively. Taken together, the data indicate that the $B$. pilosa extract and compound 54 act on human and mouse $\mathrm{T}$ cells. To test the in vivo effect of the B. pilosa extract and compound 54, a zymosaninduced arthritis mouse model was used. This model was established from B10.A/SgSnJ mice with an injection of zymosan $(0.15 \mathrm{mg})$. The zymosan-injected mice received an intraperitoneal injection of the B. pilosa extract $(1,5$, or $10 \mathrm{mg})$ at one dose a day for 5 days. Popliteal lymph node (PLN) weight was monitored to check the development of arthritis. The results revealed that $10 \mathrm{mg}$ of the methanol extract of $B$. pilosa extract could significantly diminish inflammation as evidenced by PLN weight [18]. This work suggests that $B$. pilosa (and compound 54) can suppress immune response and inflammation.

3.3. Antidiabetic Activity. Anti-diabetic agents are primarily developed from plants and other natural resources [7, 4346]. B. pilosa is one of 1,200 plant species that have been investigated for antidiabetic activity $[119,120]$. B. pilosa is used as an anti-diabetic herb in America, Africa, and Asia $[45,119,121]$. Many studies have indicated that $B$. pilosa could treat type 1 diabetes (T1D) and type 2 diabetes (T2D) in animals.

Etiologically speaking, T1D is caused by autoimmunemediated destruction of pancreatic $\beta$ cells, leading to insulin deficiency, hyperglycemia, and complications. Currently, there is no cure for T1D. Polarization of Th cell differentiation controls the development of T1D. Suppression of Thl cell differentiation and promotion of Th2 cell differentiation ameliorate T1D [122]. One study showed that the butanol fraction of B. pilosa inhibited T-cell proliferation, decreased Th1 cells and cytokines, and increased Th2 cells and cytokines, leading to prevention of T1D in nonobese diabetic
TABLE 12: Structure and activity relationship studies of ethyl caffeate using in vitro NF- $\kappa \mathrm{B} / \mathrm{DNA}$ binding assays [38].

\begin{tabular}{lcc}
\hline Compound & $\begin{array}{c}\text { Concentration } \\
(\mu \mathrm{M})\end{array}$ & $\begin{array}{c}\text { NF- } \kappa \mathrm{B} / \\
\text { DNA binding }\end{array}$ \\
\hline Ethyl caffeate & 50 & $\begin{array}{c}100 \% \\
\text { inhibition } \\
100 \%\end{array}$ \\
Ethyl 3,4-dihydroxyhydrocinnamate & 100 & $\begin{array}{c}\text { inhibition } \\
100 \%\end{array}$ \\
Catechol & 400 & $\begin{array}{c}\text { inhibition } \\
\text { No }\end{array}$ \\
Ethyl cinnamate & 400 & \begin{tabular}{c} 
inhibition \\
\hline
\end{tabular}
\end{tabular}

(NOD) mice [44]. Based on a bioactivity-directed isolation strategy, 3 polyynes, $2-\beta-D$-Glucopyranosyloxy-1-hydroxytrideca-5,7,9,11-tetrayne (53), also known as cytopiloyne, 3- $\beta$-D-Glucopyranosyl-1-hydroxy-6(E)-tetradecene-8,10,12triyne (69), 2- $\beta$-D-Glucopyranosyloxy-1-hydroxy-5(E)-tridecene-7,9,11-triyne (50) were identified from B. pilosa $[44,46]$. The $\mathrm{IC}_{50}$ value of the butanol fraction was $200 \mu \mathrm{g} / \mathrm{mL}$. This inhibition was reported to be partially attributed to cytotoxicity because the butanol fraction at $180 \mu \mathrm{g} / \mathrm{mL}$ could cause $50 \%$ death of Thl cells. Moreover, this study suggested that the butanol fraction may prevent diabetes in NOD mice in vivo via downregulation of Th1 cells or upregulation Th2 cells that have effects which are antagonistic of those of Th1 cells [44]. This was proven by intraperitoneal injection of the butanol fraction at a dose of $3 \mathrm{mg} / \mathrm{kg}$ BW, 3 times a week, to NOD mice from 4 to 27 weeks. This dosage resulted in lower incidence of diabetes (33\%). At a dose of $10 \mathrm{mg} / \mathrm{kg}$, the butanol fraction of B. pilosa totally eliminated $(0 \%)$ the initiation of the disease. To further support this result, assessment of IgG2a and IgE production was performed in the serum of NOD mice. As in vivo results obtained from intracellular cytokine staining, experiments were not very conclusive levels of IgG2a and IgE were measured since Th1 cytokine IFN $\gamma$; and Th2 cytokine IL- 4 favor the production of IgG2a and IgE, respectively. As expected, high levels of IgE and some decline in the levels of IgG2a were observed in the serum. Profiling of the butanol extract revealed five compounds, 3- $\beta$-D-Glucopyranosyl-1hydroxy-6(E)-tetradecene-8,10,12-triyne (69), 2- $\beta$ - $D$ - Glucopyranosyloxy-1-hydroxy-5(E)-tridecene-7,9,11-triyne (50), 4, 5-Di-O-caffeoylquinic acid, 3,5-Di-O-caffeoylquinic acid, and 3,4-Di-O-caffeoylquinic acid. Only the first two compounds showed similar effects on the prevention of diabetes in NOD mice as the B. pilosa butanol fraction. Moreover, compound $\mathbf{5 0}$ showed greater activity than compound 69 in terms of enhancement (by $34 \%$ compared to $8 \%$ ) of differentiation of Th0 to Th2 at $15 \mu \mathrm{g} / \mathrm{mL}$ (both compounds) and inhibition (by $40 \%$ compared to 10\%) of differentiation to Th1 at the same concentration [44].

Among the three polyynes found in B. pilosa, cytopiloyne (53) had the most potent anti-T1D activity [46]. To test the in vivo effect of cytopiloyne, NOD mice received intraperitoneal or intramuscular injection of cytopiloyne at $25 \mu \mathrm{g} / \mathrm{kg} \mathrm{BW}$, 3 times per week. Twelve-week-old NOD mice started to 
develop T1D, and $70 \%$ of NOD mice aged 23 weeks and over developed T1D. Remarkably, 12- to 30-week-old NOD mice treated with cytopiloyne showed normal levels of blood glucose $(<200 \mathrm{mg} / \mathrm{dL})$ and insulin $(1-2 \mathrm{ng} / \mathrm{mL})$. Consistent with T1D incidence, cytopiloyne delayed and reduced the invasion of $\mathrm{CD}^{+} \mathrm{T}$ cells into the pancreatic islets [46].

In vitro study showed that cytopiloyne (53) inhibited the differentiation of naïve $\mathrm{Th}(\mathrm{Th} 0)$ cells (i.e., $\mathrm{CD}^{+} \mathrm{T}$ cells) into Th1 cells and promoted differentiation of Th0 cells into Th2 cells [50]. The in vitro data are consistent with the in vivo results indicating that cytopiloyne reduced Thl differentiation and increased Th2 differentiation as shown by intracellular cytokine staining and FACS analysis [46]. In line with the skewing of Th differentiation, the level of serum IFN- $\gamma$ and IgG2c decreased while that of serum IL-4 and serum IgE increased compared to the negative controls (PBS-treated mice). Cytopiloyne also enhanced the expression of GATA3 , a master gene for Th2 cell differentiation, but not the expression of T-bet, a master gene for Th1 cell differentiation, further supporting its role in skewing Th differentiation [46].

Also importantly, cytopiloyne partially depleted $\mathrm{CD}^{+}$ rather than $\mathrm{CD}^{+} \mathrm{T}$ cells in NOD mice [46]. As shown in Table 13, coculture assays showed that the depletion of $\mathrm{CD} 4^{+}$ $\mathrm{T}$ cells was mediated through the induction of Fas ligand expression on pancreatic islet cells by cytopiloyne, leading to apoptosis of infiltrating $\mathrm{CD}_{4}^{+} \mathrm{T}$ cells in the pancreas via the Fas and Fas ligand pathways. However, cytopiloyne did not induce the expression of TNF- $\alpha$ in pancreatic islet cells and, thus, had no effect on $\mathrm{CD} 8^{+} \mathrm{T}$ cells [46].

In addition, Chang and colleagues showed that cytopiloyne dose-dependently inhibited T-cell proliferation stimulated by IL-2 plus Con A or anti-CD3 antibody, using $\left[{ }^{3} \mathrm{H}\right]$ thymidine incorporation assay [46].

Overall, the mechanism of action of cytopiloyne and, probably, its derivatives in T1D includes inhibition of T-cell proliferation, skewing of Th cell differentiation, and partial depletion of Th cells. Due to the anti-diabetic mechanisms of action, it was hypothesized that cytopiloyne protects NOD mice from diabetes by a generalized suppression of adaptive immunity. To evaluate this hypothesis, ovalbumin (Ova) was used as a T-cell dependent antigen to prime NOD mice, which had already received cytopiloyne or PBS vehicle. Ova priming boosted similar anti-Ova titers in cytopiloyne-treated mice and PBS-treated mice, but a difference in immunoglobulin isotype was observed in the two groups. Thus, it was concluded that cytopiloyne is an immunomodulatory compound rather than an immunosuppressive compound [46, 50].

T2D is a chronic metabolic disease with serious complications resulting from defects in either insulin secretion, insulin action, or both [123]. A study by Ubillas et al. showed that the aqueous ethanol extract of the aerial part of B. pilosa at $1 \mathrm{~g} / \mathrm{kg}$ body weight (BW) lowered blood glucose in $\mathrm{db} / \mathrm{db}$ mice, a T2D mouse model [45]. Based on a bioactivity-guided identification, compounds 69 and 50 were identified. Further, the mixture of the compounds $(69: 50)$ in a $2: 3$ ratio significantly decreased blood glucose concentration and reduced food intake on the second day
TABLE 13: Apoptosis in cocultures of T cells and pancreatic $\beta$ cells [46].

\begin{tabular}{|c|c|}
\hline Cell/Medium & $\begin{array}{l}\% \text { Apoptosis and } \\
\text { necrosis }\end{array}$ \\
\hline $\mathrm{CD}^{+}{ }^{+} \mathrm{T}$ cells/control medium & $<4$ \\
\hline $\begin{array}{l}\mathrm{CD} 4^{+} \mathrm{T} \text { cells/with PBS-treated } \beta \text { cells } \\
\text { of NOD-SCID mice }\end{array}$ & 2 \\
\hline $\mathrm{CD}^{+}{ }^{+} \mathrm{T}$ cells/with cytopiloyne-treated $\beta$ cells & 18 \\
\hline $\begin{array}{l}\mathrm{CD} 4^{+} \mathrm{T} \text { cells/with cytopiloyne-treated } \beta \text { cells in } \\
\text { the presence of } \alpha \text {-FasL antibody }\end{array}$ & 7 \\
\hline $\mathrm{CD}^{+} \mathrm{T}$ cells/control medium & 4 \\
\hline $\begin{array}{l}\mathrm{CD}^{+} \mathrm{T} \text { cells/with PBS-treated } \beta \text { cells } \\
\text { of NOD-SCID mice }\end{array}$ & 4 \\
\hline $\mathrm{CD}^{+} \mathrm{T}$ cells/with cytopiloyne-treated $\beta$ cells & 4 \\
\hline $\begin{array}{l}\mathrm{CD} 8^{+} \mathrm{T} \text { cells/with cytopiloyne-treated } \beta \text { cells in } \\
\text { the presence of } \alpha \text {-FasL antibody }\end{array}$ & 4 \\
\hline
\end{tabular}

of treatment when administered at doses of $250 \mathrm{mg} / \mathrm{kg}$ twice a day to $\mathrm{C} 5 \mathrm{BL} / \mathrm{Ks}-\mathrm{db} / \mathrm{db}$ mice. When tested at $500 \mathrm{mg} / \mathrm{kg}$, a more substantial drop in blood glucose level as well as the stronger anorexic effect (food intake reduced from $5.8 \mathrm{~g} /$ mouse/day to $2.5 \mathrm{~g} /$ mouse/day) was observed [45]. In this study, it was suggested that the blood glucose lowering effect of $B$. pilosa was caused, in part, by the hunger suppressing effect of its polyynes [45]. However, the hunger suppressing effect of the ethanol extract of $B$. pilosa was not found in the studies described below. In another study [43], water extracts of B. pilosa (BPWE) were used in diabetic $\mathrm{db} / \mathrm{db}$ mice, aged 6-8 weeks, with postprandial blood glucose levels of 350 to $400 \mathrm{mg} / \mathrm{dL}$. Like oral antidiabetic glimepiride, which stimulates insulin release, one single dose of BPWE reduced blood glucose levels from 374 to $144 \mathrm{mg} / \mathrm{dL}$. The antihyperglycemic effect of BPWE was inversely correlated to an increase in serum insulin levels, suggesting that BPWE acts to lower blood glucose via increased insulin production. However, BPWE had different insulin secretion kinetics to glimepiride [43]. One flaw in current anti-diabetics is their decreasing efficacy over time. The authors investigated the long term anti-diabetic effect of BPWE in $\mathrm{db} / \mathrm{db}$ mice. BPWE reduced blood glucose, increased blood insulin, improved glucose tolerance, and reduced the percentage of glycosylated hemoglobin (HbAlc). Both long-term and one-time experiments strongly support the anti-diabetic action of BPWE [43]. In sharp contrast to glimepiride, BPWE protected against islet atrophy in mouse pancreas. The investigators further evaluated anti-diabetic properties of 3 B. pilosa varieties, B. pilosa L. var. radiate (BPR), B.pilosa L. var. pilosa (BPP), and B. pilosa L. var. minor $(\mathrm{BPM})$ in $\mathrm{db} / \mathrm{db}$ mice [7]. One single oral dose $(10,50$ and $250 \mathrm{mg} / \mathrm{kg}$ body weight) of BPR, BPP, or BPM crude extracts decreased postprandial blood glucose levels in $\mathrm{db} / \mathrm{db}$ mice for up to four hours, and the reduction of glucose levels in the blood appeared to be dose-dependent. Comparing the three variants, BPR extract resulted in a higher reduction in blood glucose levels when administered at the same dose as the other two varieties. In terms of serum insulin levels, a dose 
of $50 \mathrm{mg} / \mathrm{kg}$ of each extract was used, and the BPR extract, together with the three polyynes, significantly increased the serum insulin level in $\mathrm{db} / \mathrm{db}$ mice. Long-term experiments (28-day treatment) were then conducted using diabetic mice with postprandial glucose levels from 370 to $420 \mathrm{mg} / \mathrm{dL}$, and glimepiride was used as positive control. The range of dosages applied was from $10 \mathrm{mg} / \mathrm{kg}$ BW to $250 \mathrm{mg} / \mathrm{kg}$ BW. Results showed that the positive control as well as the crude extracts of the three varieties lowered the blood glucose levels in $\mathrm{db} / \mathrm{db}$ mice. However, only BPR extract, containing a higher percentage of cytopiloyne (53), reduced blood glucose levels and augmented blood insulin levels more than BPP and BPM. The percentage of glycosylated hemoglobin Alc (HbAlc) was also measured and found to be $7.9 \% \pm 0.5 \%$ in mice aged $10-$ 12 weeks, and $6.6 \% \pm 0.2 \%, 6.1 \% \pm 0.3 \%$ and $6.2 \% \pm 0.3 \%$ in the blood of age-matched mice following treatment with BPR crude extract $(50 \mathrm{mg} / \mathrm{kg})$, glimepiride $(1 \mathrm{mg} / \mathrm{kg})$, and compound $53(0.5 \mathrm{mg} / \mathrm{kg})$, respectively [7]. Among the polyynes found in $B$. pilosa, cytopiloyne was the most effective against T2D. Hence, cytopiloyne was used for further study on antidiabetic action and mechanism [124]. The data confirmed that cytopiloyne reduced postprandial blood glucose levels, increased blood insulin, improved glucose tolerance, suppressed HbAlc level, and protected pancreatic islets in $\mathrm{db} / \mathrm{db}$ mice. Nevertheless, cytopiloyne failed to decrease blood glucose in streptoztocin (STZ)-treated mice whose b cells were already destroyed. Additionally, cytopiloyne dosedependently increased insulin secretion and expression in $\mathrm{b}$ cells as well as calcium influx, diacylglycerol, and activation of protein kinase $\mathrm{C} \alpha$. Collectively, the mechanistic studies suggest that cytopiloyne treats $\mathrm{T} 2 \mathrm{D}$ via regulation of insulin production involving the calcium/DAG/PKC $\alpha$ cascade in $b$ cells.

The studies detailed above point to the conclusion that cytopiloyne and related polyynes (compounds 69 and 49) are anti-diabetics in animal models. The data uncover a new biological action of polyynes. It should be noted that, like all anti-diabetic drugs, cytopiloyne failed to prevent or cure diabetes completely but reduced diabetic complications [124]. Intriguingly, 34 polyynes have been found in $B$. pilosa so far. It remains to be seen whether all the polyynes present in this plant have anti-diabetic activities.

3.4. Antioxidant Activity. Free radicals can damage cellular components via a series of chemical reactions [48] leading to development and progression of cardiovascular disease, cancer, neurodegenerative diseases and ageing [47]. Free radicals, nitric oxide (NO), and superoxide anions can be produced in macrophages to kill microbes. However, an excessive generation of the free radicals under pathological conditions is associated with a wide range of illnesses. Plants are known to be rich in antioxidant phytochemicals. Chiang and colleagues evaluated the free radical scavenging activity of crude extract, fractions, and compounds of $B$. pilosa using 1,1-diphenyl-2-picrylhydrazyl (DPPH) and hypoxanthine/xanthine oxidase assays [47]. Using DPPH and hypoxanthine/xanthine oxidase assays, they found that the $B$. pilosa crude extract and the ethyl acetate, butanol, and water fractions had free radical scavenging activity. Nine compounds, Heptyl-2-O- $\beta$-xylofuranosyl$(1 \rightarrow 6)$ - $\beta$-glucopyranoside (199), 3-O-Rabinobioside (124), Quercetin 3-O-rutinoside (130), Chlorogenic acid (167), 3,4Di-O-caffeoylquinic acid (169), 3,5-Di-O-caffeoylquinic acid (170), 4,5-Di-O-caffeoylquinic acid (171), Jacein (119), and Centaurein (110) had DPPH radical scavenging activity [47]. The $\mathrm{IC}_{50}$ values of the $B$. pilosa crude extract/fractions and compounds are summarized in Tables 14 and 15, respectively.

Measurement of free radical scavenging activities is one way of assessing the antioxidant activities of $B$. pilosa and its fractions and compounds. It is interesting that the ethyl acetate and butanol fractions are more active than the water fraction and $B$. pilosa crude extract [47]. Of the secondary metabolites, only phenolic compounds 124, 130,167, 169, and 171 showed significant DPPH-radical scavenging activities. Further analysis of the structure-activity relationship of the compounds suggested that substitution of the C3 hydroxyl group with glycosides increased the activity approximately 2 -fold (for example, in compounds 124 and 130) relative to quercetin (-OH in its $\mathrm{C} 3$ ) [47]. Further modification of the structures of the active compounds needs to be performed to test the effects of various substituents on activity. The reason why most of the antioxidant compounds contain phenol moieties in their structure could be that the reductionoxidation (redox) properties of phenols allow them to act as reducing agents, singlet oxygen quenchers, and hydrogen donors.

A complementary study by Muchuweti and colleagues determined phenolic content, antioxidant activity, and the phenolic profile of $B$. pilosa methanol extract [48]. They estimated that the phenolic content of the methanol extract of B. pilosa was $1102.8 \pm 2.2 \mathrm{mg} / \mathrm{g}$ [48]. Vanillin, hydroxybenzaldehyde, caffeic acid, coumaric acid, and ferulic acid were found in this extract. The B. pilosa extract also showed DPPH radical scavenging activity. Furthermore, the antioxidant activity of the flavonoids found in B. pilosa was correlated with its hepatoprotective effects through their inhibition of NF- $\kappa \mathrm{B}$ activation which may lessen the oxidative stress caused by the production of free radicals during liver injury [81]. This activity might also be due to the anti-inflammatory effects of the aqueous extracts of $B$. pilosa aerial parts on the inhibition of COX-2 and $\mathrm{PGE}_{2}$ production [42].

Essential oils from $B$. pilosa flowers and leaves are also reported to possess antioxidant activity. With the aim of replacing chemically synthesized additives, Deba and colleagues [53] worked on the antioxidant, antibacterial, and antifungal activities of essential oils and water extracts of $B$. pilosa's leaves and flowers. Table 16 summarizes the results obtained from DPPH free radical scavenging assay.

It can be inferred from Table 16 that essential oils from the leaves possessed the highest activity. It is reported elsewhere that monoterpenes present in essential oils such that of $B$. pilosa have protective effects and antioxidant properties [53]. Beta-carotene bleaching method was also performed. Leaves essential oils and aqueous extracts of the leaves and flowers showed higher activity than the flower essential oils. This is due to the volatility of the flower essential oils. The activity exhibited by the aqueous extracts was accounted to the 
TABLE 14: Radical scavenging activities of B. pilosa extracts [47].

\begin{tabular}{lcc}
\hline Extracts/control & $\begin{array}{c}\mathrm{DPPH} \text { assay, } \\
\mathrm{IC}_{50}(\mu \mathrm{g} / \mathrm{mL})\end{array}$ & $\begin{array}{c}\text { NBT/hypoxanthine } \\
\text { superoxide assay, } \\
\mathrm{IC}_{50}(\mu \mathrm{g} / \mathrm{mL})\end{array}$ \\
\hline Quercetin & 1.98 & 1.5 \\
Ascorbic acid & 6.34 & Not determined \\
$\alpha$-tocopherol & 8.97 & Not determined \\
Ethyl acetate & 13.83 & 59.7 \\
extract & 16.69 & 11.4 \\
Butanol extract & $>100$ & $>100$ \\
Water extract & &
\end{tabular}

TABLE 15: Radical scavenging activity of secondary metabolites from B. pilosa [47].

\begin{tabular}{lc}
\hline Metabolite (Table 11)/Control & DPPH assay, $\mathrm{IC}_{50}(\mu \mathrm{g} / \mathrm{mL})$ \\
\hline $\mathbf{1 9 9}$ & Not determined \\
$\mathbf{1 2 4}$ & 5.3 \\
$\mathbf{1 3 0}$ & 6.8 \\
$\mathbf{1 6 7}$ & 10.5 \\
$\mathbf{1 6 9}$ & 3.3 \\
$\mathbf{1 7 1}$ & 3.8 \\
$\mathbf{1 1 9}$ & Not determined \\
$\mathbf{1 1 0}$ & Not determined \\
Quercetin & 2.56 \\
Caffeic acid & 8.90 \\
\hline
\end{tabular}

TABLE 16: Antioxidant activity of the essential oils and water extracts from B. pilosa [53].

\begin{tabular}{lc}
\hline Extract & $\mathrm{IC}_{50}(\mu \mathrm{g} / \mathrm{mL})$ \\
\hline Leaf essential oils & 47 \\
Flower essential oils & 50 \\
Leaf extract & 61 \\
Flower extract & 172 \\
\hline
\end{tabular}

presence of phenolic compounds that are reported to donate a hydrogen atom to free radicals such that the propagation of the chain reaction during lipid oxidation is terminated [53]. Overall, essential oils and phenolics present in B. pilosa can be thought of as major antioxidant compounds.

3.5. Immunomodulatory Activity. B. pilosa is thought to be an immunomodulatory plant and is reported to be effective in the treatment of immune disorders such as allergy [37], arthritis [37], and T1D [46, 50, 73].

As pointed out in the discussion of its anti-diabetic activities (Section 3.3), a combination of phytochemicals method and T-cell activation assays was used to study immunomodulatory properties of $B$. pilosa. IFN- $\gamma$ is a key cytokine released by $\mathrm{T}$ and NK cells that mediates immune cells and sustains immunity against pathogens. Defects in IFN- $\gamma$ expression, regulation, and activation result in vulnerability to diseases caused by bacteria and viruses [29]. An elegant study, performed by Chang and colleagues using IFN- $\gamma$ promoter-driven luciferase reporter construct in Jurkat $\mathrm{T}$ cells, showed that hot water crude extracts of B. pilosa increased IFN- $\gamma$ promoter activity two-fold [29]. Out of the subfractions of this extract, the butanol fraction, but not the water or ethyl acetate, fractions, increased IFN $-\gamma$ promoter activity six-fold. Centaurein (110) and centaureidin (109) were identified from the butanol fraction and were stated to cause a four-fold increase in IFN- $\gamma$ promoter activity with $\mathrm{EC}_{50}$ values of $75 \mu \mathrm{g} / \mathrm{mL}$ and $0.9 \mu \mathrm{g} / \mathrm{mL}$, respectively. The mechanism of action of centaurein was determined using transcription factors such as AP-1, NFAT, and NF $\kappa$ B which are reported to bind to IFN- $\gamma$ promoter and regulate IFN- $\gamma$ transcription. Unlike with the activity of the positive control, PHA, centaurein caused a four-fold increase in NFAT, a 3 -fold increase in $\mathrm{NF} \kappa \mathrm{B}$ and had little, if any, effect on AP-1 enhancer activities (23-fold, three-fold, and ten-fold increases, respectively, were seen with PHA) [29]. The authors concluded that centaurein modulates IFN- $\gamma$ expression by the $\mathrm{NFAT}$ and $\mathrm{NF} \kappa \mathrm{B}$ pathways. The article only determined the mechanism of action of centaurein. Its aglycone centaureidin may act through the same mechanism though this conclusion needs to be further verified.

B. pilosa extract and its compounds are reported to inhibit differentiation of naïve $\mathrm{CD}^{+}$helper $\mathrm{T}(\mathrm{Th} 0)$ cells into Th1 cells [44]. Using the Th cell differentiation assay as a screening platform, 3 polyynes, $2-\beta$-D-glucopyranosyloxy-1hydroxytrideca-5,7,9,11-tetrayne (53), 3- $\beta$-D-glucopyranosyl1-hydroxy-6(E)-tetradecene-8,10,12-triyne (69), and 2- $\beta$-Dglucopyranosyloxy-1-hydroxy-5(E)-tridecene-7,9,11-triyne (49) were discovered from B. pilosa $[44,46]$. The data shows that cytopiloyne and other two polyynes suppressed the differentiation of type 1 helper $\mathrm{T}$ (Th1) cells and production of Th1 cytokines and promoted that of type 2 helper T (Th2) cells and production of Th2 cytokines, thus explaining the immunomodulatory and anti-inflammatory effects of $B$. pilosa and its polyynes.

Chang and colleagues were the first to report the effect of the butanol extract of $B$. pilosa on the autoimmune diabetes and airway inflammation in mice [73]. Imbalance in the levels of Th1 and Th2 and of various cytokines leads to autoimmune diseases. T1D and other autoimmune diseases (rheumatoid arthritis, Crohn's disease, among others) are exacerbated by an increase Th1 levels (specifically, $\mathrm{CD} 4^{+} \mathrm{Th} 1$ cells) while Th2 cells antagonize this effect [56]. Moreover, Th2 cells mediate asthma in ovalbumin-induced hypersensitivity in BALB/c mice [73]. In their work [73], Chang and colleagues showed that $10 \mathrm{mg} / \mathrm{kg}$ butanol extracts with $1.5 \%$ (w/w) compound 69 and 1.1\% (w/w) compound 49 (Table 11) ameliorated the development of Thl-mediated diabetes in NOD mice through inhibition of $\beta$ cell death and leukocyte infiltration. At the same dosage, the butanol extracts also exacerbated ovalbumin-induced pulmonary inflammation in $\mathrm{BALB} / \mathrm{c}$ mice with an increase in the infiltration of eosinophils and mast cells into the airway of the mice [73]. Despite the different outcomes, both mouse models proved the concept that control over the Th1/Th2 shift is associated with autoimmune diseases and that the B. pilosa butanol extract can shift the differentiation of Th0 cells to Th2 cells $[44,73]$. 
An extended study presented by Chiang and colleagues showed that compound $\mathbf{5 3}$ modulates T-cell functions [50]. Using $\mathrm{CD} 4^{+} \mathrm{T}$ cells from $\mathrm{BALB} / \mathrm{c}$ mice, they demonstrated that cytopiloyne decreased levels of IFN- $\gamma$ producing cells (Th1) by $12.2 \%$ (from $72 \%$ to $59.8 \%$ ). Since Th1 and Th2 cell differentiation is antagonistic, it was expected that compound 53 increased the percentage of mouse IL-4 producing cells (Th2) by $7.2 \%$ (from $23.7 \%$ to $30.9 \%$ ). Subsequent assessment of effect of compound $\mathbf{5 3}$ on the modulation of the transcription of IL- 4 and IFN- $\gamma$ showed that cytopiloyne, as expected, decreased the splenocyte levels of IFN- $\gamma$ mRNA and increasing that of IL- 4 in a dose-dependent manner. In the range of 0.1 to $3 \mu \mathrm{g} / \mathrm{mL}$ of compound 53 , the effects were not attributed to its cytotoxicity. Consequently, using $3 \mu \mathrm{g} / \mathrm{mL}$ cytopiloyne for 72 and 96 hours, the protein concentration of IFN- $\gamma$ decreased to $18.6 \%$ and $44.4 \%$, respectively. Under the same conditions, cytopiloyne increased IL-4 concentrations to $198.5 \%$ and $247.0 \%$ (for 72 and 96 hours, resp.). This modulation of T-cell differentiation exhibited by compound 53 was used to explain its anti-diabetic activity [50].

The anti-diabetic role of cytopiloyne was extensively discussed above (Section 3.3, anti-diabetic activity). The molecular basis of the regulation of cytokine expression by cytopiloyne has been described. Cytopiloyne directly elevated the expression level of IL-4 via GATA-3 upregulation in $\mathrm{T}$ cells [46]. However, reduction of IFN- $\gamma$ expression in T cells seemed to come from the indirect opposing effect IL-4 cytokine because the expression level of T-bet was unaltered [46]. In this way, cytopiloyne skewed Thl polarization into the Th2 state, conferring protection against T1D in NOD mice. Aside from polarization of Th cell differentiation, cytopiloyne also activated the expression of Fas ligand in pancreatic $\mathrm{b}$ cells, this increase leading to the partial depletion of $\mathrm{T}$ cells and reduction of immune response in local areas such as the pancreas. Of note, cytopiloyne also inhibited T-cell proliferation and activation. By targeting $\mathrm{T}$ cells from three immunomodulatory actions, cytopiloyne protects against T1D and probably other Th1-mediated autoimmune diseases [56].

The phytochemical constituents of B. pilosa exert their functions on different immune cells to modulate immune response. It is possible that some of the compounds may have agonistic or antagonistic effects on immune response. Immune function of B. pilosa may depend on its composition and amount of compounds, which could explain the apparently conflicting report of B. pilosa butanol extract aggravating allergy in mice [73] while cellulosine-treated extract ameliorated allergy $[37,73]$. IFN- $\gamma$ promoter reporter assays and T-cell differentiation assays were used to isolate 2 flavonoids [29] and 3 polyynes [44, 50] as immunomodulatory compounds from the butanol fraction of B. pilosa. Interestingly, the flavonoids promote IFN- $\gamma$ expression in $\mathrm{NK}$ and $\mathrm{T}$ cells. In marked contrast, the polyynes promote IL-4 expression and indirectly inhibit IFN- $\gamma$ expression in differentiating T cells. Sensitivity appears to be the key to identifying structure- and bioactivity-related phytochemicals from medicinal plants.
3.6. Antimalarial Activity. The use of chemical drugs against pathogens has resulted in drug-resistant mutants. Examples of drug resistance can be found in the species of the Plasmodium that cause malaria. It is important to search for new compounds to combat Plasmodium parasites [51]. A study of the anti-malarial activity of the leaf extracts of $B$. pilosa using a combination of phytochemistry and bioassays showed that compound 49 (Table 11) showed activity against a malaria parasite (P. falciparum NF54 strain) with an $\mathrm{IC}_{50}$ value of $6.0 \mu \mathrm{g} / \mathrm{mL}$ [30]. In addition, compound 49 , isolated from the aerial parts of $B$. pilosa, inhibited growth of the $P$. falciparum FCR-3 strain with an $\mathrm{IC}_{50}$ value of $0.35 \mu \mathrm{g} / \mathrm{mL}$. This compound was tested for its in vivo effect in mice infected with $P$. berghei NK-65 strain. Results showed that compound 49 decreased the average parasitemia in the red blood cells by 20.7 (from $32.8 \%$ of that of the control to $12.1 \%$ ) after an intravenous injection of $0.8 \mathrm{mg} / \mathrm{kg}$ BW/day for four days [51]. Further studies addressing the anti-malarial mechanism underlying both polyynes and clinical studies are needed.

3.7. Antibacterial Activity. Emergence of multiple antibioticresistant microbes is becoming a global threat to public health and a challenge to disease treatment. For instance, penicillin is commonly used to combat a food-borne intracellular bacterium Listeria; however, penicillin-resistant bacteria have been discovered recently [29]. Chang and coworkers isolated centaurein (110) and centaureidin (109) from B. pilosa extract $[29,47]$. Centaurein enhances expression of IFN- $\gamma$, a key cytokine for macrophage activation and, consequently, enhances bactericidal activity in macrophages [29, 47]. In agreement with observed in vitro effects, centaurein was reported to prevent and treat Listeria infection in C57BL/6J mice [52]. Mechanistic studies confirmed that centaurein exerted antilisterial action via IFN- $\gamma$ expression in wild-type mice but not IFN- $\gamma$ knockout mice [52]. Further in vitro studies on centaurein showed that this compound increased IFN- $\gamma$ expression by $13 \%$ (from $17 \%$ to $20 \%$ ), $20 \%$ (from $21 \%$ to $41 \%$ ), and $11 \%$ (from $6 \%$ to $17 \%$ ) in $\mathrm{CD}^{+} \mathrm{T}$ cells, $\mathrm{CD} 8^{+} \mathrm{T}$ cells, and NK cells, respectively. That is to say, there was an increase in IFN- $\gamma$ producing immune cells. As expected, centaurein also enhanced the expression level of T-bet, a key nuclear factor for IFN- $\gamma$ expression. Consistently, centaurein augmented the serum IFN- $\gamma$ levels in C57BL/6J mice, and this augmentation peaked 24 hours after compound injection. The quantity of mouse serum IFN- $\gamma$ was sufficient to activate macrophages in vitro and eradicated GFP-producing Listeria inside macrophages. However, the entry of Listeria into macrophages was not affected by centaurein-treated mouse sera. Centaurein treatment at $20 \mu \mathrm{g}$ per mouse rescued $30 \%$ of the mice infected with a lethal dose of Listeria $(2 \times$ $\left.10^{6} \mathrm{CFU}\right)$. It is noteworthy that in the presence of ampicillin $(5 \mu \mathrm{g} /$ mouse), centaurein $(20 \mu \mathrm{g} /$ mouse $)$ rescued $70 \%$ of the mice, suggesting an additive effect between ampicillin and centaurein [52]. Despite lower abundance, centaureidin was 30 times more active than centaurein in terms of IFN- $\gamma$ production [52].

Aside from the indirect antibacterial action mentioned above, extract and/or compounds of B. pilosa also showed 
TABle 17: Antibacterial activity of essential oils and flower extracts from B. pilosa [53].

\begin{tabular}{lcccc}
\hline \multirow{2}{*}{ Strain } & \multicolumn{2}{c}{ Mean zone of inhibition (mm) } \\
& Leaf essential oil & Flower essential oil & Leaf extract & Flower extract \\
\hline Micrococcus flavus & $12.7 \pm 0.3$ & $8.7 \pm 0.3$ & $10.2 \pm 0.2$ & $10.8 \pm 0.3$ \\
Bacillus subtilis & $17.3 \pm 1.9$ & $11.7 \pm 0.2$ & $10.9 \pm 0.2$ & $10.3 \pm 0.2$ \\
Bacillus cereus & $19.0 \pm 1.4$ & $11.2 \pm 0.3$ & $11.8 \pm 0.4$ & $18.5 \pm 1.0$ \\
Bacillus pumilus & $12.3 \pm 0.7$ & $10.8 \pm 0.2$ & $10.5 \pm 0.4$ & $7.7 \pm 0.2$ \\
Escherichia coli & $13.7 \pm 0.4$ & $20.3 \pm 0.7$ & $10.2 \pm 1.1$ & $14.0 \pm 1.3$ \\
Pseudomonas ovalis & $12.5 \pm 0.8$ & $13.7 \pm 1.5$ & $10.2 \pm 0.6$ & $12.5 \pm 0.6$ \\
\hline
\end{tabular}

direct bacteriostatic and/or bactericidal action. One study reported that essential oils and leaf/flower extracts of $B$. pilosa could suppress the growth of gram positive and gram negative bacteria as evidenced by zone of inhibition assays. In this study, antibacterial activity of the essential oils from the leaves and flowers of B. pilosa was determined in an attempt to identify natural products as food preservatives for prevention of microbial multiplication and food oxidation. The essential oils and extracts of B. pilosa leaves and flowers showed moderate but different extents of antibacterial activity (Table 17). In general, essential oils had higher antibacterial activity than crude extracts. One explanation for this could be that monoterpenes in the essential oils destroy cellular integrity and, subsequently, inhibit the respiration and ion transport processes. The presence of antibacterial $\beta$-caryophyllene could be another explanation as reported elsewhere [53]. Another study reported that the methanol and acetone extract of $B$. pilosa roots displayed antibacterial activities against the bacteria listed in Table 18 [54] and methanol extracts from the roots seemed to be the most effective.

Another study indicated that the polyyne, (R)-1,2dihydroxytrideca-3,5,7,9,11-pentayne (49), from this plant also suppressed bacterial growth as shown by the minimum inhibitory concentration required to inhibit 50\% bacterial growth $\left(\mathrm{MIC}_{50}\right)$ in Table 19 . This compound was highly effective against several Gram positive and Gram negative bacteria including the drug-resistant bacteria Staphylococcus aureus N315 (MRSA) and Enterococcus faecalis NCTC12201 (VRE) [51]. Strikingly, compound 49 had a similar $\mathrm{MIC}_{50}$ value to antibiotics (ampicillin, tetracycline, norfloxacin, and amphotericin B) in most of the bacteria tested.

Antibacterial activity of B. pilosa extracts and components, expressed as $\mathrm{MIC}_{50}$ and the mean zone of inhibition, is tabulated in Tables 17, 18, and 19. The zone of inhibition for Ampicilline (positive control) ranges from $15.3 \pm 0.3 \mathrm{~mm}$ to $44.3 \pm 0.2 \mathrm{~mm}[53]$.

3.8. Antifungal Activity. B. pilosa has traditionally been used to treat microbial infection. Recently, different parts of $B$. pilosa have been tested for antifungal activities. Deba and colleagues first evaluated the antifungal effect of the hot water extracts of the B. pilosa roots, stems, and leaves against Corticium rolfsii, Fusarium solani, and Fusarium oxysporum. They discovered that $C$. rolfsii was most suppressed by treatment with $B$. pilosa as its growth was reduced at almost
TABLE 18: Antibacterial activity of root extracts from B. pilosa [54].

\begin{tabular}{lcc}
\hline \multirow{2}{*}{ Strain } & \multicolumn{2}{c}{ MIC $_{50}(\mathrm{mg} / \mathrm{mL})$} \\
& Methanol extract & Acetone extract \\
\hline Bacillus cereus & 10 & - \\
Escherichia coli & 5 & 5 \\
Klebsilla pneumonia & 5 & 10 \\
Micrococcus kristinae & 10 & - \\
Pseudomonas aeruginosa & 10 & 10 \\
Staphylococcus aureus & 5 & 10 \\
Sraphylococcus epidermidis & 5 & 5 \\
Serratia marcescens & 10 & - \\
Shigelea flexneri & 10 & - \\
Streptococcus faecalis & 10 & - \\
\hline
\end{tabular}

TABLE 19: Antibacterial activity of B. pilosa of compound 29 [51].

\begin{tabular}{lc}
\hline Strain & MIC $_{50}(\mu \mathrm{g} / \mathrm{mL})$ \\
\hline Escherichia coli NIHJ & 1 \\
Escherichia coli ATCC25922 & 1 \\
Klebsiella pneumoniae ATCC700603 & 128 \\
Serratia marcescens ATCC13880 & 16 \\
Pseudomonas aeruginosa ATCC27853 & 8 \\
Staphylococcus aureus FDA209P & 0.5 \\
Staphylococcus aureus ATCC29213 & 0.25 \\
Staphylococcus aureus N315 (MRSA) & 0.5 \\
Enterococcus faecalis ATCC29212 & 2 \\
Enterococcus faecalis NCTC12201 (VRE) & 1 \\
Bacillus subtilis ATCC6633 & 0.5 \\
Candida albicans ATCC10231 & 0.25 \\
\hline
\end{tabular}

all the tested doses, followed by F. oxysporum and F. solani [97]. However, the fungicidal activities of the stems, and roots were greater than the leaves [97]. Moreover, the same group assessed the antifungal activity of the essential oils and aqueous extracts from $B$. pilosa flowers and leaves [53]. They showed that the extracts and oils had antifungal activity against C. rolfsii, F. solani, and F. oxysporum. Essential oils appeared to have better fungicidal activity than water extracts as summarized in Table 20.

Another study by Ashafa and colleagues showed that acetone, methanol, and water extracts of the B. pilosa roots showed antifungal activities against Aspergillus niger, $A$. 
TABle 20: Antifungal activity of B. pilosa [53].

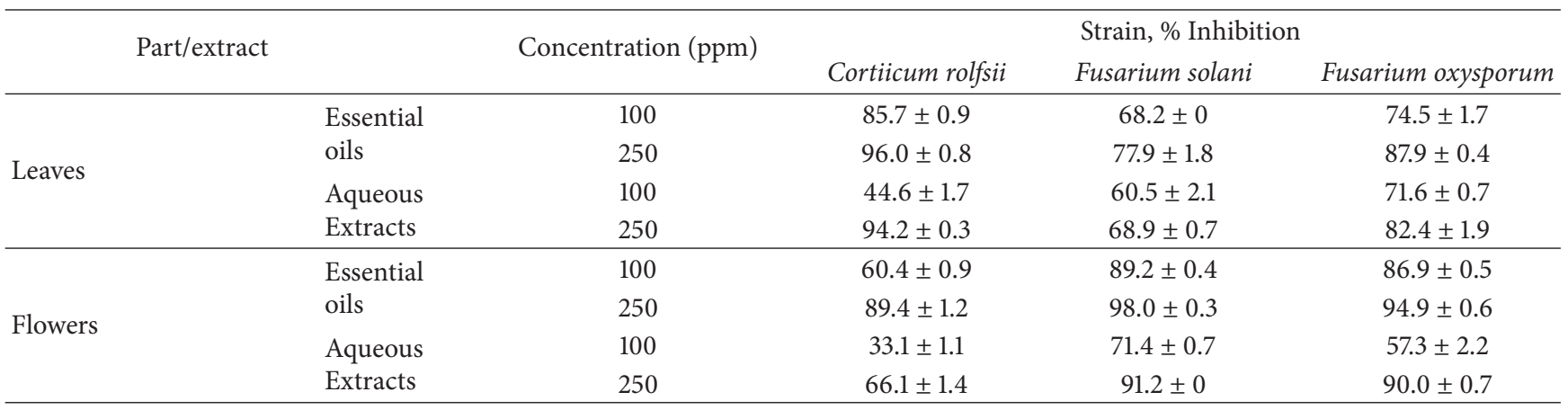

TABLE 21: Antifungal activity of B. pilosa root extracts [54].

\begin{tabular}{|c|c|c|c|}
\hline \multirow[b]{2}{*}{ Strain } & \multicolumn{3}{|c|}{$\mathrm{LC}_{50}(\mathrm{mg} / \mathrm{mL})$} \\
\hline & $\begin{array}{l}\text { Acetone } \\
\text { extracts }\end{array}$ & $\begin{array}{c}\text { Methanol } \\
\text { extracts }\end{array}$ & $\begin{array}{l}\text { Water } \\
\text { extracts }\end{array}$ \\
\hline Aspergillus niger & 0.14 & 0.06 & 0.07 \\
\hline Aspergillus flavus & 10.91 & 6.58 & 0 \\
\hline Penicillium notatum & 0.05 & 0.05 & 0.05 \\
\hline
\end{tabular}

flavus, and Penicillium notatum using the agar dilution method. The results are tabulated in Table 21 [54]. Negative controls showed $0 \%$ growth inhibition. The methanol extract of the $B$. pilosa roots at $10 \mathrm{mg} / \mathrm{mL}$ was also effective against Candida albicans [54]. Of note, B. pilosa obtained from Papua New Guinea had no activity against $A$. niger and $C$. albicans [125], but the South African (Eastern Cape) ecotype exhibited moderate activity against C. albicans [54]. This discrepancy may depend on extraction solvents, extraction procedure, assay techniques, different plant parts, and abundance of active compounds.

B. pilosa produces a variety of secondary metabolites such as flavonoids, phenylacetylenes, alkaloids, sterols, terpenoids, and tannis $[53,54]$. However, none of them have been confirmed as active compounds against fungi. Further investigation of active compounds from $B$. pilosa is necessary to further understand the antifungal efficacy of this plant.

3.9. Hypotensive and Vasodilatory Activities. In early studies, Dimo and colleagues used three rat models, normotensive Wistar rats (NTR), salt-loading hypertensive rats (SLHR), and spontaneous hypertensive rats (SHR) to investigate the hypotensive effect of the methanol crude extract of $B$. pilosa leaves $[19,126]$. The extract lowered systolic blood pressure in hypertensive rats (SLHR and SHR) to a greater degree than NTR $[19,126]$. In addition, a decrease in urinary sodium ions and an increase in urinary potassium ions were observed after treatment with the methanol extract of $B$. pilosa leaves although neither differences were statistically significant [19, 126]. Taking the data together, the study proposed that $B$. pilosa leaf extract reduced blood pressure via vasodilation [19, 126]. The same group continued to test the antihypertensive effect of aqueous and methylene chloride extracts of $B$. pilosa leaves in a hypertensive rat model $[19,126]$. To establish a fructose-induced hypertension model, male Wistar rats were given $10 \%$ fructose solution to drink ad libitum for three weeks. In addition to free access to $10 \%$ fructose, the rats were treated with the aqueous $(150 \mathrm{mg} / \mathrm{kg})$ or methyl chloride $(350 \mathrm{mg} / \mathrm{kg})$ extracts of $B$. pilosa for additional three weeks $[19,126]$. Both extracts of $B$. pilosa leaves had a hypotensive effect on rats. However, neither extracts reversed the elevation of serum insulin in fructose-fed rats. Therefore, B. pilosa lowered blood pressure irrespective of insulin [19, 126]. To better understand the hypotensive mechanism, the authors investigated the effect of a neutral extract of $B$. pilosa (NBP), a mixture of methanol and methylene chloride (1:1) extract after neutralization with $\mathrm{NaOH}$ and $\mathrm{HCl}$, on the heart and the blood pressure of NTR and SHR [109]. This study showed that an intravenous injection of the NBP resulted in a biphasic reduction in systolic blood pressure. In addition, one intravenous dose of the extract at 10,20 , and $30 \mathrm{mg} / \mathrm{kg}$ BW decreased systolic blood pressure in normal rats by $18.3 \%$, $42.5 \%$, and $30 \%$, respectively, and the same doses reduced the blood pressure in hypertensive rats by $25.8 \%, 38.9 \%$, and $28.6 \%$, respectively. Only the highest dose $(30 \mathrm{mg} / \mathrm{kg})$ affected the force of the contraction of the heart. Atropine and propranolol were used to interfere with the hypotensive action of the NBP. Atropine reduced the initial phase of the hypotensive response in NBP and completely abolished the second phase of hypotensive response in NBP. In contrast, propranolol increased the first hypotensive response but partially abolished the second hypotensive response provoked by the NBP [109]. This mechanistic study suggested that $B$. pilosa invokes the biphasic hypotensive responses via targeting cardiac pump efficiency during the first phase and vasodilation at the second phase [109].

A further study was performed to investigate the relaxing effect of a neutral extract of $B$. pilosa (NBP) on rat aorta contracted with $\mathrm{KCl}(60 \mathrm{mM})$ and norepinephrine (0.1 $\mathrm{mM})$ [55]. Cumulative addition of NBP relaxed the rat aorta previously contracted by $\mathrm{KCl}$ in a dose-dependent manner. The $\mathrm{EC}_{50}$ value of the NBP for vasorelaxation was $0.32 \mathrm{mg} / \mathrm{mL}$. The data also showed that the NBP reduced the contraction of aorta previously contracted by $\mathrm{KCl}$ irrespective of the presence of aortic endothelium [55].

Pretreatment with glibenclamide, an ATP-dependent $\mathrm{K}^{+}$ channel blocker, did not considerably affect the relaxant effect of the $\mathrm{NBP}$ on $\mathrm{KCl}$-induced contraction, suggesting that 
the vasodilatory effect of $B$. pilosa was not related to the opening of this ATP-dependent $\mathrm{K}^{+}$channel [55]. On the other hand, in the presence of indomethacin or pyrilamine maleate, the relaxant response induced by the plant extract was significantly inhibited at the lower concentrations. The plant extract was able to reduce the aorta resting tone, inhibit the $\mathrm{KCl}$-induced contractions by $90 \%$ at $1.5 \mathrm{mg} / \mathrm{mL}$ and the $\mathrm{CaCl}_{2}$-induced contractions by $95 \%$ at $0.75 \mathrm{mg} / \mathrm{mL}$. These results demonstrate that $B$. pilosa can act as a vasodilator probably via acting as a calcium antagonist [55].

However, no specific compound for the above activity has been identified from $B$. pilosa to date. A bioactivityguided identification approach may be adopted to identify the active compounds in $B$. pilosa that possess hypotensive and vasodilatory effects and understand their mechanism of action.

3.10. Wound Healing Activity. B. pilosa has been traditionally used to treat tissue injury in Cameroon, Brazil, and Venezuela [17]. Hassan and colleagues investigated the wound healing potential of $B$. pilosa in Wistar rats [127]. Mirroring the positive control neomycin sulfate, the ethanol extract of $B$. pilosa had faster wound closure than control rats 3, 6, and 9 days after topical application. Histological examination also revealed better collagenation, angiogenesis, and organization of wound tissue seven days after application. Epithelialization and total healing time in B. pilosa-treated rats were comparable to those of neomycin sulfate. Together, these data suggest that $B$. pilosa may be a viable alternative to neomycin lotion for the treatment of wounds.

In addition to studying the wound healing effect of $B$. pilosa on external ulcers, Tan and colleagues also examined the effect of methanol, cyclohexane, and methyl chloride extracts of $B$. pilosa on gastric ulcers in Wistar rats fed with $1 \mathrm{~mL} \mathrm{HCl} /$ ethanol gastric necrotizing solution $(150 \mathrm{mM}$ $\mathrm{HCl}$ in $60 \%$ ethanol), and macroscopically visible lesions were scored [17]. Among the three extracts, methylene chloride extracts exhibited the highest activity showing $46.4 \%$ inhibition of lesion formation at a dose of $500 \mathrm{mg} / \mathrm{kg} \mathrm{BW}$ and complete inhibition at $750 \mathrm{mg} / \mathrm{kg}$ [17]. The efficacy of the ethylene chloride extract was followed by that of the methanol extracts which had inhibition ranging from $30.4 \%$ to $82.2 \%$ at concentrations of $500 \mathrm{mg} / \mathrm{kg}$ and $1000 \mathrm{mg} / \mathrm{kg}$ BW, respectively [17]. The cyclohexane extracts showed the lowest activity against gastric ulcers in rats with $13.3 \%$, $40 \%$, and $79.7 \%$ inhibition at 500, 750, and $1000 \mathrm{mg} / \mathrm{kg} \mathrm{BW}$, respectively [17]. To better understand the mode of action of the methylene chloride extract of $B$. pilosa, rats were pretreated with indomethacin, a COX-2 inhibitor involved in prostaglandin synthesis. Pretreatment significantly reduced the protection against $\mathrm{HCl} /$ ethanol-induced ulcers to $31.3 \%$ inhibition at $750 \mathrm{mg} / \mathrm{kg} \mathrm{BW}$, suggesting a link between the antiulcerative activity of $B$. pilosa and prostaglandin synthesis. Unexpectedly, the methylene chloride extract of $B$. pilosa showed little gastric mucosal protection against gastric lesions induced by $95 \%$ ethanol (1 mL) [17]. Absolute alcohol is known to cause mucosal/submucosal tissue destruction via cellular necrosis and the release of tissue-derived mediators (histamine and leukotriene C4). Thus, these data imply that $B$. pilosa did not prevent the generation or the necrotic action of these mediators on the gastric microvasculature. In addition, pylorus ligation can increase gastric acid secretion without an alteration of mucosal histamine content. The methylene chloride extract of $B$. pilosa did not possess antisecretory activity. On the contrary, it was observed that increases in the dose of the extract led to elevated gastric juice acidity [17]. Results with both absolute ethanol and pylorus ligation rat models suggested the possibility that the ineffectiveness of $B$. pilosa against gastric ulcers was due to lack of antihistaminic activity in the plant. In summary, overall the data suggest that B. pilosa protects against HCL/ethanol-mediated ulcers via inhibition of prostaglandin biosynthesis.

Previous phytochemical studies showed that a group of flavonoids, acyclichalcones, are present in B. pilosa $[128,129]$ and the chalcones were proposed to have antiulcerative activity [130]. Moreover, nine hydroxychalcones were reported to possess gastric cytoprotective effects with 2,4-dihydroxychalcone being the most active [131]. Since methylene chloride extracts appear to be the most active $B$. pilosa extracts, next, the specific anti-ulcerative phytochemicals in the methylene chloride extracts of B. pilosa and their modes of action needs to be probed.

Despite the claims listed in Table 3, relatively few scientific studies have been conducted in vitro and in vivo to address the traditional ethnomedical uses of $B$. pilosa. Information about the use of $B$. pilosa as a botanical therapy recorded so far is far from complete. Studies conducted thus far only serve as a starting point for further investigation of $B$. pilosa, and the ultimate efficacious use of the herb in clinical applications.

\section{Toxicology}

Despite its use as an ingredient in food for human consumption, studies on systemic toxicity (e.g., acute, subacute, chronic and subchronic toxicities) of B. pilosa in humans and animals are still inadequate and insufficient. So far, acute, and/or subchronic toxicities have been evaluated in rats and mice. Oral acute and 28-day toxicities of water extract of $B$. pilosa leaves were evaluated in Wistar rats [132]. An oral dose of water extract of B. pilosa leaves at $10 \mathrm{~g} / \mathrm{kg}$ BW showed no obvious mortality or changes in the appearance in rats [133]. The same extract at $0.8 \mathrm{~g} / \mathrm{kg}$ BW/day, once a day, showed no obvious sub-chronic toxicity in rats over 28 days, as measured by survival rate, body weight, and gross examination of organs [133]. These data are consistent with our data indicating that oral delivery of the water extract of the $B$. pilosa whole plant at $1 \mathrm{~g} / \mathrm{kg}$ $\mathrm{BW} /$ day, once a day, is safe in rats over 28 days (unpublished data). Taken together, these studies suggest that ingestion of B. pilosa aqueous extract at up to at $1 \mathrm{~g} / \mathrm{kg}$ BW/day, once a day, is highly safe in rats. In addition, the acute toxicity of aqueous and ethanol extracts of B. pilosa in mice have been reported [133]. Five- to six-week-old mice with weights between 28 and $35 \mathrm{~g}$ received a peritoneal injection of both extracts at the different doses. The $\mathrm{LD}_{50}$, the dose that causes $50 \%$ lethality, of the aqueous and ethanol extracts in mice 
was $12.30 \mathrm{~g} / \mathrm{kg}$ BW and $6.15 \mathrm{~g} / \mathrm{kg}$ BW, respectively [133]. A complete toxicological study has not been completed for humans. Furthermore, the drug interactions of B. pilosa with other drugs are unknown. Further safety verification and clinical trials should be performed before B. pilosa can be considered for medicinal use.

\section{Conclusions}

B. pilosa is an erect, perennial plant with green leaves, white or yellow flowers and tiny black seeds. As it is distributed worldwide and is widely used as a folk remedy, B. pilosa can be thought of as an extraordinary source of food and medicine. However, a comprehensive up-to-date review of research on $B$. pilosa has hitherto been unavailable. In this article, scientific studies on B. pilosa have been summarized and critically discussed from the perspectives of botany, ethnomedicine, phytochemistry, pharmacology, and toxicology. B. pilosa is claimed to treat more than 40 disorders, and 201 compounds have been identified from this plant. The medicinal utility of B. pilosa and its modes of action in relation to its known phytochemicals were discussed herein. Polyynes, flavonoids, phenylpropanoids, fatty acids, and phenolics are the primary bioactive compounds of $B$. pilosa, and they have been reported to be effective in the treatment of tumors, inflammation/immune modulation, diabetes, viruses, microbes, protozoans, gastrointestinal diseases, hypertension, and cardiovascular diseases. Caution should be exercised in the therapeutic use of B. pilosa for hypoglycemia, hypotension, bleeding, and allergy.

\section{Acknowledgments}

The authors thank their laboratory members for constructive suggestions and the authors whose publications they cited for their contributions. The authors also thank Ms Miranda Loney of Academia Sinica for English editing of this paper. This work was supported by Grants 99-CDA-L11 and $101 S 0010056$ from Academia Sinica, Taiwan. Arlene P. Bartolome is a recipient of MECO-TECO Sandwich Scholarship Program between Taiwan and the Philippines.

\section{References}

[1] T. Shen, G. H. Li, X. N. Wang, and H. X. Lou, "The genus Commiphora: a review of its traditional uses, phytochemistry and pharmacology," Journal of Ethnopharmacology, vol. 142, no. 2, pp. 319-330.

[2] C. Long, P. Sauleau, B. David et al., "Bioactive flavonoids of Tanacetum parthenium revisited," Phytochemistry, vol. 64, no. 2, pp. 567-569, 2003.

[3] P. O. Karis and O. Ryding, Asteraceae Cladistics and Classification, Bremer K. Eds, pp. 559-569, Timber press, Portland, Ore, USA, 1994.

[4] O. N. Pozharitskaya, A. N. Shikov, M. N. Makarova et al., "Anti-inflammatory activity of a HPLC-fingerprinted aqueous infusion of aerial part of Bidens tripartita L," Phytomedicine, vol. 17, no. 6, pp. 463-468, 2010.
[5] F. Q. Oliveira, V. Andrade-Neto, A. U. Krettli, and M. G. L. Brandão, "New evidences of antimalarial activity of Bidens pilosa roots extract correlated with polyacetylene and flavonoids," Journal of Ethnopharmacology, vol. 93, no. 1, pp. 3942, 2004.

[6] Agriculture USDA, "Plants database," 2013, in: Natural Resources Conservation Service, http://www.nrcs.usda.gov/wps/ portal/nrcs/site/national/home .

[7] S. C. Chien, P. H. Young, Y. J. Hsu et al., "Anti-diabetic properties of three common Bidens pilosa variants in Taiwan," Phytochemistry, vol. 70, no. 10, pp. 1246-1254, 2009.

[8] M. J. Alcaraz and M. J. Jimenez, "Flavonoids as antiinflammatory agents," Fitoterapia, vol. 59, no. 1, pp. 25-38, 1988.

[9] FAO, Agriculture Food and Nutrition for Africa-A Resource Book for Teachers of Agriculture, Publishing Management Group, FAO Information Division, Rome, Italy, 1997.

[10] M. B. Rokaya, Z. Munzbergova, B. Timsina, and K. R. Bhattarai, "Rheum australe D. Don: a review of its botany, ethnobotany, phytochemistry and pharmacology," Journal of Ethnopharmacology, vol. 141, no. 3, pp. 761-774, 2012.

[11] P. H. Young, Y. J. Hsu, and W. C. Yang, "Bidens pilosa L. and its medicinal use," in Recent Progress in Medicinal Plants Drug Plant II, A. S. Awaad, V. K. Singh, and J. N. Govil, Eds., Standium Press, Houston, Tex, USA, 2010.

[12] C. Ge, "Cytologic study of Bidens bipinnata L," Zhongguo Zhong Yao Za Zhi, vol. 15, no. 2, pp. 72-125, 1990.

[13] L. C. Chiang, J. S. Chang, C. C. Chen, L. T. Ng, and C. C. Lin, "Anti-herpes simplex virus activity of Bidens pilosa and Houttuynia cordata," American Journal of Chinese Medicine, vol. 31, no. 3, pp. 355-362, 2003.

[14] N. P. Rybalchenko, V. A. Prykhodko, S. S. Nagorna et al., "In vitro antifungal activity of phenylheptatriyne from Bidens cernua L. against yeasts," Fitoterapia, vol. 81, no. 5, pp. 336-338, 2010.

[15] Y. Zhou and X. Z. Yan, "Experimental study of qi deficiency syndrome and Codonopsis pillosulae and Astragalus injection on the immune response in mice," Zhong Xi Yi Jie He Za Zhi, vol. 9, no. 5, pp. 286-262, 1989.

[16] K. Redl, W. Breu, B. Davis, and R. Bauer, "Anti-inflammatory active polyacetylenes from Bidens campylotheca," Planta Medica, vol. 60, no. 1, pp. 58-62, 1994.

[17] P. V. Tan, T. Dimo, and E. Dongo, "Effects of methanol, cyclohexane and methylene chlo ride extracts of Bidens pilosa on various gastric ulcer models in rats," Journal of Ethnopharmacology, vol. 73, no. 3, pp. 415-421, 2000.

[18] R. L. C. Pereira, T. Ibrahim, L. Lucchetti, A. J. R. Da Silva, and V. L. G. De Moraes, "Immunosuppressive and anti-inflammatory effects of methanolic extract and the polyacetylene isolated from Bidens pilosa L," Immunopharmacology, vol. 43, no. 1, pp. 31-37, 1999.

[19] T. Dimo, J. Azay, P. V. Tan et al., "Effects of the aqueous and methylene chloride extracts of Bidens pilosa leaf on fructosehypertensive rats," Journal of Ethnopharmacology, vol. 76, no. 3, pp. 215-221, 2001.

[20] C. Wiart, Medicinal Plants of Southeast Asia, Pelanduk, Selabgor Darul Ehsan, Malaysia, 2000.

[21] S. Dharmananda, "A Popular Remedy Ecapes Notice of Western Practitioners," 2013, http://www.itmonline.org/arts/bidens.htm

[22] C. Lans, "Comparison of plants used for skin and stomach problems in Trinidad and Tobago with Asian ethnomedicine," Journal of Ethnobiology and Ethnomedicine, vol. 3, article 3, 2007. 
[23] M. Ayyanar and S. Ignacimuthu, "Traditional knowledge of Kani tribals in Kouthalai of Tirunelveli hills, Tamil Nadu, India," Journal of Ethnopharmacology, vol. 102, no. 2, pp. 246-255, 2005.

[24] J. H. Cano and G. Volpato, "Herbal mixtures in the traditional medicine of Eastern Cuba," Journal of Ethnopharmacology, vol. 90, no. 2-3, pp. 293-316, 2004.

[25] P. Geissberger and U. Sequin, "Constituents of Bidens pilosa L.: do the components found so far explain the use of this plant in traditional medicine?" Acta Tropica, vol. 48, no. 4, pp. 251-261, 1991.

[26] E. Noumi, F. Houngue, and D. Lontsi, "Traditional medicines in primary health care: plants used for the treatment of hypertension in Bafia, Cameroon," Fitoterapia, vol. 70, no. 2, pp. 134-139, 1999.

[27] F. L. Silva, D. C. H. Fischer, J. F. Tavares, M. S. Silva, P. F. De Athayde-Filho, and J. M. Barbosa-Filho, "Compilation of secondary metabolites from Bidens pilosa L," Molecules, vol. 16, no. 2, pp. 1070-1102, 2011.

[28] L. W. Wu, Y. M. Chiang, H. C. Chuang et al., "A novel polyacetylene significantly inhibits angiogenesis and promotes apoptosis in human endothelial cells through activation of the CDK inhibitors and caspase-7," Planta Medica, vol. 73, no. 7, pp. 655-661, 2007.

[29] S. L. Chang, Y. M. Chiang, C. L. T. Chang et al., "Flavonoids, centaurein and centaureidin, from Bidens pilosa, stimulate IFN$\gamma$ expression," Journal of Ethnopharmacology, vol. 112, no. 2, pp. 232-236, 2007.

[30] P. Kumari, K. Misra, B. S. Sisodia et al., "A promising anticancer and antimalarial component from the leaves of Bidens pilosa," Planta Medica, vol. 75, no. 1, pp. 59-61, 2009.

[31] G. Seelinger, I. Merfort, U. Wölfle, and C. M. Schempp, "Anticarcinogenic effects of the flavonoid luteolin," Molecules, vol. 13, no. 10, pp. 2628-2651, 2008.

[32] G. Seelinger, I. Merfort, and C. M. Schempp, "Anti-oxidant, anti-inflammatory and anti-allergic activities of luteolin," Planta Medica, vol. 74, no. 14, pp. 1667-1677, 2008.

[33] C. C. Yit and N. P. Das, "Cytotoxic effect of butein on human colon adenocarcinoma cell proliferation," Cancer Letters, vol. 82, no. 1, pp. 65-72, 1994.

[34] J. A. Beutler, E. Hamel, A. J. Vlietinck et al., "Structure-activity requirements for flavone cytotoxicity and binding to tubulin," Journal of Medicinal Chemistry, vol. 41, no. 13, pp. 2333-2338, 1998.

[35] M. R. Kviecinski, K. B. Felipe, T. Schoenfelder et al., "Study of the antitumor potential of Bidens pilosa (Asteraceae) used in Brazilian folk medicine," Journal of Ethnopharmacology, vol. 117, no. 1, pp. 69-75, 2008.

[36] P. Sundararajan, A. Dey, A. Smith, A. G. Doss, M. Rajappan, and S. Natarajan, "Studies of anticancer and antipyretic activity of Bidens pilosa whole plant," African Health Sciences, vol. 6, no. 1, pp. 27-30, 2006.

[37] M. Horiuchi and Y. Seyama, "Improvement of the antiinflammatory and antiallergic activity of Bidens pilosa L. var. radiata SCHERFF treated with enzyme (Cellulosine)," Journal of Health Science, vol. 54, no. 3, pp. 294-301, 2008.

[38] Y. M. Chiang, C. P. Lo, Y. P. Chen et al., "Ethyl caffeate suppresses $\mathrm{NF}-\kappa \mathrm{B}$ activation and its downstream inflammatory mediators, iNOS, COX-2, and PGE2 in vitro or in mouse skin," British Journal of Pharmacology, vol. 146, no. 3, pp. 352-363, 2005.

[39] J. S. Kim, H. J. Lee, M. H. Lee, J. Kim, C. Jin, and J. H. Ryu, "Luteolin inhibits LPS-stimulated inducible nitric oxide synthase expression in BV-2 microglial cells," Planta Medica, vol. 72, no. 1, pp. 65-68, 2006.

[40] P. A. Ruiz and D. Haller, "Functional diversity of flavonoids in the inhibition of the proinflammatory NF- $\kappa \mathrm{B}$, IRF, and Akt signaling pathways in murine intestinal epithelial cells," Journal of Nutrition, vol. 136, no. 3, pp. 664-671, 2006.

[41] A. Xagorari, A. Papapetropoulos, A. Mauromatis, M. Economou, T. Fotsis, and C. Roussos, "Luteolin inhibits an endotoxin-stimulated phosphorylation cascade and proinflammatory cytokine production in macrophages," Journal of Pharmacology and Experimental Therapeutics, vol. 296, no. 1, pp. 181-187, 2001.

[42] N. Yoshida, T. Kanekura, Y. Higashi, and T. Kanzaki, “Bidens pilosa suppresses interleukin- $1 \beta$-induced cyclooxygenase-2 expression through the inhibition of mitogen activated protein kinases phosphorylation in normal human dermal fibroblasts," Journal of Dermatology, vol. 33, no. 10, pp. 676-683, 2006.

[43] Y. J. Hsu, T. H. Lee, C. L. T. Chang, Y. T. Huang, and W. C. Yang, "Anti-hyperglycemic effects and mechanism of Bidens pilosa water extract," Journal of Ethnopharmacology, vol. 122, no. 2, pp. 379-383, 2009.

[44] S. L. Chang, C. L. T. Chang, Y. M. Chiang et al., "Polyacetylenic compounds and butanol fraction from Bidens pilosa can modulate the differentiation of helper T cells and prevent autoimmune diabetes in non-obese diabetic mice," Planta Medica, vol. 70, no. 11, pp. 1045-1051, 2004.

[45] R. P. Ubillas, C. D. Mendez, S. D. Jolad et al., "Antihyperglycemic acetylenic glucosides from Bidens pilosa," Planta Medica, vol. 66, no. 1, pp. 82-83, 2000.

[46] C. L. T. Chang, S. L. Chang, Y. M. Lee et al., "Cytopiloyne, a polyacetylenic glucoside, prevents type 1 diabetes in nonobese diabetic mice," Journal of Immunology, vol. 178, no. 11, pp. 69846993, 2007.

[47] Y. M. Chiang, D. Y. Chuang, S. Y. Wang, Y. H. Kuo, P. W. Tsai, and L. F. Shyur, "Metabolite profiling and chemopreventive bioactivity of plant extracts from Bidens pilosa," Journal of Ethnopharmacology, vol. 95, no. 2-3, pp. 409-419, 2004.

[48] M. Muchuweti, C. Mupure, A. Ndhlala, T. Murenje, and M. A. N. Benhura, "Screening of antioxidant and radical scavenging activity of Vigna ungiculata, Bidens pilosa and Cleome gynandra," American Journal of Food Technology, vol. 2, no. 3, pp. 161$168,2007$.

[49] L. P. Yuan, F. H. Chen, L. Ling et al., "Protective effects of total flavonoids of Bidens bipinnata L. against carbon tetrachlorideinduced liver fibrosis in rats," Journal of Pharmacy and Pharmacology, vol. 60, no. 10, pp. 1393-1402, 2008.

[50] Y. M. Chiang, C. L. T. Chang, S. L. Chang, W. C. Yang, and L. F. Shyur, "Cytopiloyne, a novel polyacetylenic glucoside from Bidens pilosa, functions as a T helper cell modulator," Journal of Ethnopharmacology, vol. 110, no. 3, pp. 532-538, 2007.

[51] S. Tobinaga, M. K. Sharma, W. G. L. Aalbersberg et al., "Isolation and identification of a potent antimalarial and antibacterial polyacetylene from Bidens pilosa," Planta Medica, vol. 75, no. 6, pp. 624-628, 2009.

[52] S. L. Chang, H. H. Yeh, Y. S. Lin, Y. M. Chiang, T. K. Wu, and W. C. Yang, "The effect of centaurein on interferon$\gamma$ expression and Listeria infection in mice," Toxicology and Applied Pharmacology, vol. 219, no. 1, pp. 54-61, 2007.

[53] F. Deba, T. D. Xuan, M. Yasuda, and S. Tawata, "Chemical composition and antioxidant, antibacterial and antifungal activities of the essential oils from Bidens pilosa Linn. var. Radiata," Food Control, vol. 19, no. 4, pp. 346-352, 2008. 
[54] A. O. T. Ashafa and A. J. Afolayan, "Screening the root extracts from Biden pilosa L. var. radiata (Asteraceae) for antimicrobial potentials," Journal of Medicinal Plant Research, vol. 3, no. 8, pp. 568-572, 2009.

[55] T. B. Nguelefack, T. Dimo, E. P. Nguelefack Mbuyo, P. V. Tan, S. V. Rakotonirina, and A. Kamanyi, "Relaxant effects of the neutral extract of the leaves of Bidens pilosa linn on isolated rat vascular smooth muscle," Phytotherapy Research, vol. 19, no. 3, pp. 207-210, 2005.

[56] A. K. Abbas, K. M. Murphy, and A. Sher, "Functional diversity of helper T lymphocytes," Nature, vol. 383, no. 6603, pp. 787-793, 1996.

[57] J. Namukobe, J. M. Kasenene, B. T. Kiremire et al., “Traditional plants used for medicinal purposes by local communities around the Northern sector of Kibale National Park, Uganda," Journal of Ethnopharmacology, vol. 136, no. 1, pp. 236-245, 2011.

[58] A. H. Chen, S. R. Lin, and C. H. Hong, "Phytochemical study on Bidens pilosa L. var. minor," Huaxue, pp. 38-42, 1975.

[59] C. K. Lee, "The low polar constituents from Bidens pilosa L. var. minor (blume) sherff," Journal of the Chinese Chemical Society, vol. 47, no. 5, pp. 1131-1136, 2000.

[60] M. C. Zulueta, M. Tada, and C. Y. Ragasa, "A diterpene from Bidens pilosa," Phytochemistry, vol. 38, no. 6, pp. 1449-1450, 1995.

[61] J. Wang, H. Yang, Z. W. Lin, and H. D. Sun, "Flavonoids from Bidens pilosa var. radiata," Phytochemistry, vol. 46, no. 7, pp. 1275-1278, 1997.

[62] A. Zhao, Q. Zhao, L. Peng et al., "A new chalcone glycoside from Bidens pilosa," Acta Botanica Yunnanica, vol. 26, no. 1, pp. 121126.

[63] P. Gao, Y. Wu, S. Cui, and Y. Zou, "Synthesis and absolute configuration of the 7-phenylhepta-4, 6-diyne-1, 2-diol isolated from Bidens pilosa," Synthesis, no. 13, pp. 2131-2135, 2011.

[64] S. Wang, B. Yang, D. Zhu, D. He, and L. Wang, "Active components of Bidens pilosa L," Zhongcaoyao, vol. 36, pp. 2021.

[65] F. Bohlmann, T. Burkhardt, and C. Zdero, Naturally Occuring Acetylenes, Academic Press, New York, NY, USA, 1973.

[66] T. M. Sarg, A. M. Ateya, N. M. Farrag, and F. A. Abbas, "Constituents and biological activity of Bidens pilosa L. grown in Egypt," Acta Pharmaceutica Hungarica, vol. 61, no. 6, pp. 317323, 1991.

[67] H. A. L. Valdés and H. P. Rego, “Bidens pilosa Linné," Revista Cubana de Plantas Medicinales, vol. 6, pp. 28-33.

[68] F. Bohlmann, H. Bornowski, and K. M. Kleine, "New polyynes from the tribe Heliantheae," Chemische Berichte, vol. 97, pp. 2135-2138.

[69] R. Wang, Q. X. Wu, and Y. P. Shi, "Polyacetylenes and flavonoids from the aerial parts of Bidens pilosa," Planta Medica, vol. 76, no. 9, pp. 893-896, 2010.

[70] L. W. Wu, Y. M. Chiang, H. C. Chuang et al., "Polyacetylenes function as anti-angiogenic agents," Pharmaceutical Research, vol. 21, no. 11, pp. 2112-2119, 2004.

[71] H. L. Yang, S. C. Chen, N. W. Chang et al., "Protection from oxidative damage using Bidens pilosa extracts in normal human erythrocytes," Food and Chemical Toxicology, vol. 44, no. 9, pp. 1513-1521, 2006.

[72] H. Q. Wang, S. J. Lu, H. Li, and Z. H. Yao, "EDTA-enhanced phytoremediation of lead contaminated soil by Bidens maximowicziana," Journal of Environmental Sciences, vol. 19, no. 12, pp. 1496-1499, 2007.
[73] C. L. T. Chang, H. K. Kuo, S. L. Chang et al., "The distinct effects of a butanol fraction of Bidens pilosa plant extract on the development of Th1-mediated diabetes and Th2-mediated airway inflammation in mice," Journal of Biomedical Science, vol. 12, no. 1, pp. 79-89, 2005.

[74] L. Alvarez, S. Marquina, M. L. Villarreal, D. Alonso, E. Aranda, and G. Delgado, "Bioactive polyacetylenes from Bidens pilosa," Planta Medica, vol. 62, no. 4, pp. 355-357, 1996.

[75] G. Kusano, A. Kusano, and Y. Seyama, Novel Hypoglycemic and Anti-Inflammatory Polyacetylenic Compounds, Their Compositions, Bidens Plant Extract Fractions, and Compositions Containing the Plant or Fraction, JPO, Tokyo, Japan, 2004.

[76] M. G. L. Brandão, A. U. Krettli, L. S. R. Soares, C. G. C. Nery, and H. C. Marinuzzi, "Antimalarial activity of extracts and fractions from Bidens pilosa and other Bidens species (Asteraceae) correlated with the presence of acetylene and flavonoid compounds," Journal of Ethnopharmacology, vol. 57, no. 2, pp. 131-138, 1997.

[77] A. U. Krettli, V. F. Andrade-Neto, M. D. G. L. Brandão, and W. M. S. Ferrari, "The search for new anti-malarial drugs from plants used to treat fever and malaria or plants ramdomly selected: a review," Memorias do Instituto Oswaldo Cruz, vol. 96, no. 8, pp. 1033-1042, 2001.

[78] C. K. Lee, "The low polar constituents from Bidens pilosa L. var. minor (blume) sherff," Journal of the Chinese Chemical Society, vol. 47, no. 5, pp. 1131-1136, 2000.

[79] C. K. Wat, R. K. Biswas, E. A. Graham, L. Bohm, G. H. N. Towers, and E. R. Waygood, "Ultraviolet-mediated cytotoxic activity of phenylheptatriyne from Bidens pilosa L," Journal of Natural Products, vol. 42, no. 1, pp. 103-111, 1979.

[80] Y. Sashida, K. Ogawa, M. Kitada, H. Karikome, Y. Mimaki, and H. Shimomura, "New aurone glucosides and new phenylpropanoid glucosides from Bidens pilosa," Chemical and Pharmaceutical Bulletin, vol. 39, no. 3, pp. 709-711, 1991.

[81] L. P. Yuan, F. H. Chen, L. Ling et al., "Protective effects of total flavonoids of Bidens pilosa L. (TFB) on animal liver injury and liver fibrosis," Journal of Ethnopharmacology, vol. 116, no. 3, pp. 539-546, 2008.

[82] B. Hoffmann and J. Hölzl, "Acylated compounds from Bidens pilosa," Planta Medica, vol. 55, pp. 108-109.

[83] B. Hoffmann and J. Hölzl, "A methylated chalcone glucoside from Bidens pilosa," Phytochemistry, vol. 27, no. 11, pp. 37003701, 1988.

[84] B. Hoffmann and J. Hölzl, "Chalcone glucosides from Bidens pilosa," Phytochemistry, vol. 28, no. 1, pp. 247-250, 1989.

[85] B. Hoffmann and J. Hölzl, "New chalcones from Bidens pilosa," Planta Medica, vol. 54, no. 1, pp. 52-54.

[86] B. Hoffmann and J. Hölzl, "Weitere acylierte chalkone aus Bidens pilosa," Planta Medica, vol. 54, pp. 450-451, 1988.

[87] V. V. Pham, V. V. T. K P, V. L. Hoang, and V. K. Phan, "Flavonoid compounds from the plant Bidens pilosa L., (Asteraceae)," Tap Chi Duoc Hoc, vol. 50, pp. 48-53.

[88] S. D. Sarker, B. Bartholomew, R. J. Nash, and N. Robinson, “5O-methylhoslundin: an unusual flavonoid from Bidens pilosa (Asteraceae)," Biochemical Systematics and Ecology, vol. 28, no. 6, pp. 591-593, 2000.

[89] A. Kusano, Y. Seyama, E. Usami et al., "Studies on the antioxidant active constituents of the dried powder from Bidens pilosa L. var. radiata Sch," Natural Medicines, vol. 57, no. 3, pp. 100-104, 2003. 
[90] I. Dolečková, L. Rárová, J. Grúz et al., “Anti-proliferative and anti-angiogenic effects of flavone eupatorin, an active constituent of chloroform extract of Orthosiphon stamineus leaves," Fitoterapia, vol. 83, no. 6, pp. 1000-1007.

[91] K. Bairwa, R. Kumar, R. J. Sharma, and R. K. Roy, "An updated review on Bidens pilosa L," Der Pharma Chemica, vol. 2, no. 3, pp. 325-337.

[92] Q. Xia, Y. Liu, and Y. Li, "Determination of hyperoside in different parts and different species of Herba Bidens by RPHPLC," West China Journal of Pharmaceutical Sciences, vol. 50, pp. $48-53$.

[93] M. G. L. Brandão, C. G. C. Nery, M. A. S. Mamão, and A. U. Krettli, "Two methoxylated flavone glycosides from Bidens pilosa," Phytochemistry, vol. 48, no. 2, pp. 397-400, 1998.

[94] M. T. Grombone-Guaratini, K. L. Silva-Brandão, V. N. Solferini, J. Semir, and J. R. Trigo, "Sesquiterpene and polyacetylene profile of the Bidens pilosa complex (Asteraceae: Heliantheae) from Southeast of Brazil," Biochemical Systematics and Ecology, vol. 33, no. 5, pp. 479-486, 2005.

[95] L. L. Lin, C. Y. Wu, H. C. Hsiu, M. T. Wang, and H. Chuang, "Studies on diabetes mellitus. I. The hypoglycemic activity of phytosterin on alloxan diabetic rats," Taiwan Yi Xue Hui Za Zhi, vol. 66, no. 2, pp. 58-65, 1967.

[96] M. A. N. Benhura and I. C. Chitsiku, "The extractable $\beta$ carotene content of Guku (Bidens pilosa) leaves after cooking, drying and storage," International Journal of Food Science and Technology, vol. 32, no. 6, pp. 495-500, 1997.

[97] F. Deba, T. D. Xuan, M. Yasuda, and S. Tawata, "Herbicidal and fungicidal activities and identification of potential phytotoxins from Bidens pilosa L. var. radiata Scherff: research paper," Weed Biology and Management, vol. 7, no. 2, pp. 77-83, 2007.

[98] J. K. Kumar and A. K. Sinha, "A new disubstituted acetylacetone from the leaves of Bidens pilosa Linn," Natural Product Research, vol. 17, no. 1, pp. 71-74, 2003.

[99] K. Ogawa and Y. Sashida, "Caffeoyl derivatives of a sugar lactone and its hydroxy acid from the leaves of Bidens pilosa," Phytochemistry, vol. 31, no. 10, pp. 3657-3658, 1992.

[100] Q. Xia, Y. Liu, and Y. Li, "Determination of gallic acid from different species and different medical parts of Herba Bidens by RP-HPLC, West China Journal of Pharmaceutical Sciences, vol. 24, no. 03, pp. 308-310.

[101] J. S. Chang, L. C. Chiang, C. C. Chen, L. T. Liu, K. C. Wang, and C. C. Lin, "Atileukemic activity of Bidens pilosa 1. var. minor (blume) sherff and Houttuynia cordata thunb," American Journal of Chinese Medicine, vol. 29, no. 2, pp. 303-312, 2001.

[102] W. J. Lee, L. F. Wu, W. K. Chen, C. J. Wang, and T. H. Tseng, "Inhibitory effect of luteolin on hepatocyte growth factor/scatter factor-induced HepG2 cell invasion involving both MAPK/ERKs and PI3K-Akt pathways," Chemico-Biological Interactions, vol. 160, no. 2, pp. 123-133, 2006.

[103] J. A. Beutler, J. H. Cardellina, C. M. Lin, E. Hamel, G. M. Cragg, and M. R. Boyd, "Centaureidin, a cytotoxic flavone from Polymnia fruticosa, inhibits tubulin polymerization," Bioorganic and Medicinal Chemistry Letters, vol. 3, no. 4, pp. 581-584, 1993.

[104] A. Verma, A. Su, A. M. Golin, B. O’Marrah, and J. K. Amorosa, "The lateral view: a screening method for knee trauma," Academic Radiology, vol. 8, no. 5, pp. 392-397, 2001.

[105] J. Corren, M. Lemay, Y. Lin, L. Rozga, and R. K. Randolph, "Clinical and biochemical effects of a combination botanical product (ClearGuard) for allergy: a pilot randomized doubleblind placebo-controlled trial," Nutrition Journal, vol. 7, no. 1, article 20, 2008.
[106] M. S. Gachet, J. S. Lecaro, M. Kaiser et al., "Assessment of antiprotozoal activity of plants traditionally used in Ecuador in the treatment of leishmaniasis," Journal of Ethnopharmacology, vol. 128, no. 1, pp. 184-197, 2010.

[107] W. C. Yang, M. Ghiotto, B. Barbarat, and D. Olive, "The role of Tec protein-tyrosine kinase in T cell signaling," The Journal of Biological Chemistry, vol. 274, no. 2, pp. 607-617, 1999.

[108] S. Tewtrakul, H. Miyashiro, N. Nakamura et al., "HIV-1 integrase inhibitory substances from Coleus parvifolius," Phytotherapy Research, vol. 17, no. 3, pp. 232-239, 2003.

[109] T. Dimo, T. B. Nguelefack, P. V. Tan et al., "Possible mechanisms of action of the neutral extract from Bidens pilosa L. leaves on the cardiovascular system of anaesthetized rats," Phytotherapy Research, vol. 17, no. 10, pp. 1135-1139, 2003.

[110] T. S. C. Li, Chinese and Related North American Herbs, CRC Press, New York, NY, USA, 2002.

[111] H. Wu, H. Chen, X. Hua, Z. Shi, L. Zhang, and J. Chen, "Clinical therapeutic effect of drug-separated moxibustion on chronic diarrhea and its immunologic mechanisms," Journal of Traditional Chinese Medicine, vol. 17, no. 4, pp. 253-258, 1997.

[112] S. W. Wright, R. R. Harris, J. S. Kerr et al., "Synthesis, chemical, and biological properties of vinylogous hydroxamic acids: dual inhibitors of 5-lipoxygenase and IL-1 biosynthesis," Journal of Medicinal Chemistry, vol. 35, no. 22, pp. 4061-4068, 1992.

[113] W. R. Almirón and M. E. Brewer, "Classification of immature stage habitats of Culicidae (Diptera) collected in Cordoba, Argentina," Memorias do Instituto Oswaldo Cruz, vol. 91, no. 1, pp. 1-9, 1996.

[114] N. L. Wang, J. Wang, X. S. Yao, and S. Kitanaka, "Two new monoterpene glycosides and a new (+)-jasmololone glucoside from Bidens parviflora Willd," Journal of Asian Natural Products Research, vol. 9, no. 5, pp. 473-479, 2007.

[115] P. Champagnat, "Role of the terminal bud in the action exercised by the cotyledon of Bidens pilosus L. var. radiatus on its axillary bud," Comptes Rendus des Séances et Mémoires de la Société de Biologie, vol. 145, no. 17-18, pp. 1374-1376, 1951.

[116] S. F. Nielsen, S. B. Christensen, G. Cruciani, A. Kharazmi, and T. Liljefors, "Antileishmaniai chalcones: statistical design, synthesis, and three-dimensional quantitative structure-activity relationship analysis," Journal of Medicinal Chemistry, vol. 41, no. 24, pp. 4819-4832, 1998.

[117] Y. C. Hwang, J. J. H. Chu, P. L. Yang, W. Chen, and M. V. Yates, "Rapid identification of inhibitors that interfere with poliovirus replication using a cell-based assay," Antiviral Research, vol. 77, no. 3, pp. 232-236, 2008.

[118] V. F. Andrade-Neto, M. G. L. Brandão, F. Q. Oliveira et al., "Antimalarial activity of Bidens pilosa L. (Asteraceae) ethanol extracts from wild plants collected in various localities or plants cultivated in humus soil," Phytotherapy Research, vol. 18, no. 8, pp. 634-639, 2004.

[119] R. J. Marles and N. R. Farnsworth, "Anti-diabetic plants and their active constituents," Phytomedicine, vol. 2, no. 2, pp. 137189.

[120] M. Habeck, "Diabetes treatments get sweet help from nature," Nature Medicine, vol. 9, no. 10, p. 1228, 2003.

[121] H. W. Lin, G. Y. Han, and S. X. Liao, "Studies on the active constituents of the Chinese traditional medicine Polygonatum odoratum (Mill.) Druce," Acta Pharmaceutica Sinica, vol. 29, no. 3, pp. 215-222, 1994.

[122] C. L. T. Chang, Y. C. Chen, H. M. Chen, N. S. Yang, and W. C. Yang, "Natural cures for type 1 diabetes: a review 
of phytochemicals, biological actions, and clinical potential," Current Medicinal Chemistry, vol. 20, no. 7, pp. 899-907, 2013.

[123] L. Dey, A. S. Attele, and C. S. Yuan, "Alternative therapies for type 2 diabetes," Alternative Medicine Review, vol. 7, no. 1, pp. 45-58, 2002.

[124] C. L. T. Chang, H. Y. Liu, T. F. Kuo et al., "Anti-diabetic effect and mode of action of cytopiloyne," Evidence-Based Complementary and Alternative Medicine, vol. 2013, Article ID 685642, 13 pages, 2013.

[125] M. R. Khan, M. Kihara, and A. D. Omoloso, "Anti-microbial activity of Bidens pilosa, Bischofia javanica, Elmerillia papuana and Sigesbekia orientalis," Fitoterapia, vol. 72, no. 6, pp. 662-665, 2001.

[126] T. Dimo, T. B. Nguelefack, P. Kamtchouing, É. Dongo, A. Rakotonirina, and S. V. Rakotonirina, "Hypotensive effects of methanol extract from Bidens pilosa Linn on hypertensive rats," Comptes Rendus de l'Academie des Sciences. Serie III, vol. 322, no. 4, pp. 323-329, 1999.

[127] A. K. Hassan, O. Deogratius, J. F. Nyafuono, O. Francis, and O. P. Engeu, "Wound healing potential of the ethanolic extracts of Bidens pilosa and Ocimum suave," African Journal of Pharmacy and Pharmacology, vol. 5, no. 2, pp. 132-136, 2011.

[128] B. Hoffmann and J. Hölzl, "Chalcone glucosides from Bidens pilosa," Phytochemistry, vol. 28, no. 1, pp. 247-250, 1989.

[129] B. Hoffmann and J. Holzl, "New chalcones from Bidens pilosa," Planta Medica, vol. 54, no. 1, pp. 52-54.

[130] C. Kandaswami and E. Middleton, "Free radical scavenging and antioxidant activity of plant flavonoids," Advances in Experimental Medicine and Biology, vol. 366, pp. 351-376, 1994.

[131] K. Yamamoto, H. Kakegawa, H. Ueda et al., "Gastric cytoprotective anti-ulcerogenic actions of hydroxychalcones in rats," Planta Medica, vol. 58, no. 5, pp. 389-393, 1992.

[132] J. O. C. Ezeonwumelu, A. K. Julius, C. N. Muhoho et al., "Biochemical and histological studies of aqueous extract of Bidens pilosa leaves from Ugandan Rift valley in rats," British Journal of Pharmacology and Toxicology, vol. 2, no. 6, pp. 302309.

[133] L. Frida, S. Rakotonirina, A. Rakotonirina, and J. P. Savineau, "In vivo and in vitro effects of Bidens pilosa L. (Asteraceae) leaf aqueous and ethanol extracts on primed-oestrogenized rat uterine muscle," African Journal of Traditional, Complementary and Alternative Medicines, vol. 5, no. 1, pp. 79-91, 2008. 


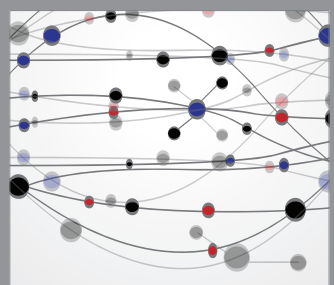

The Scientific World Journal
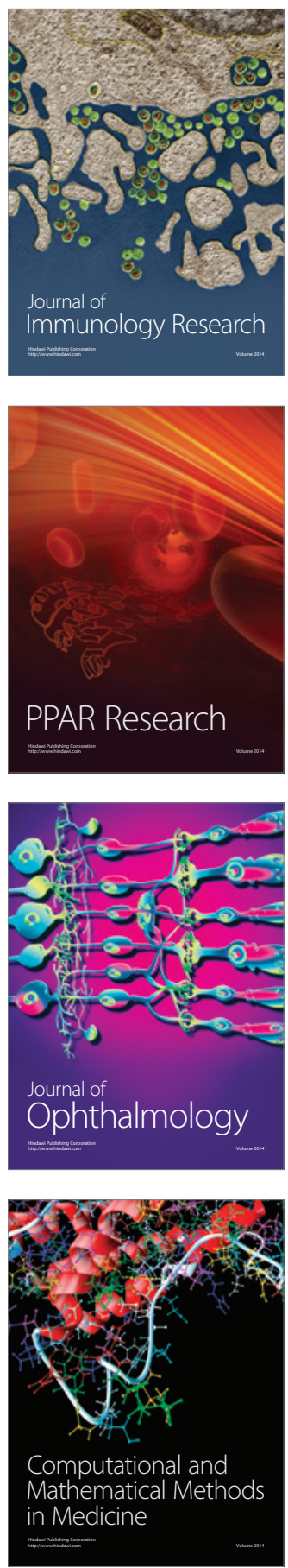

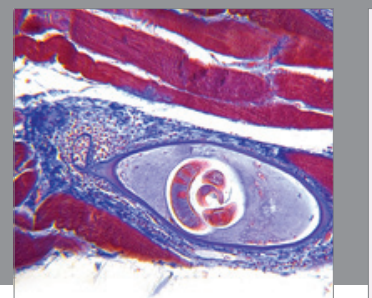

Gastroenterology

Research and Practice
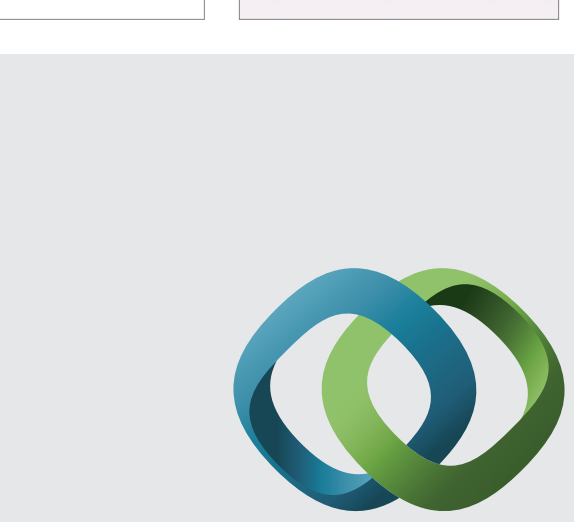

\section{Hindawi}

Submit your manuscripts at

http://www.hindawi.com
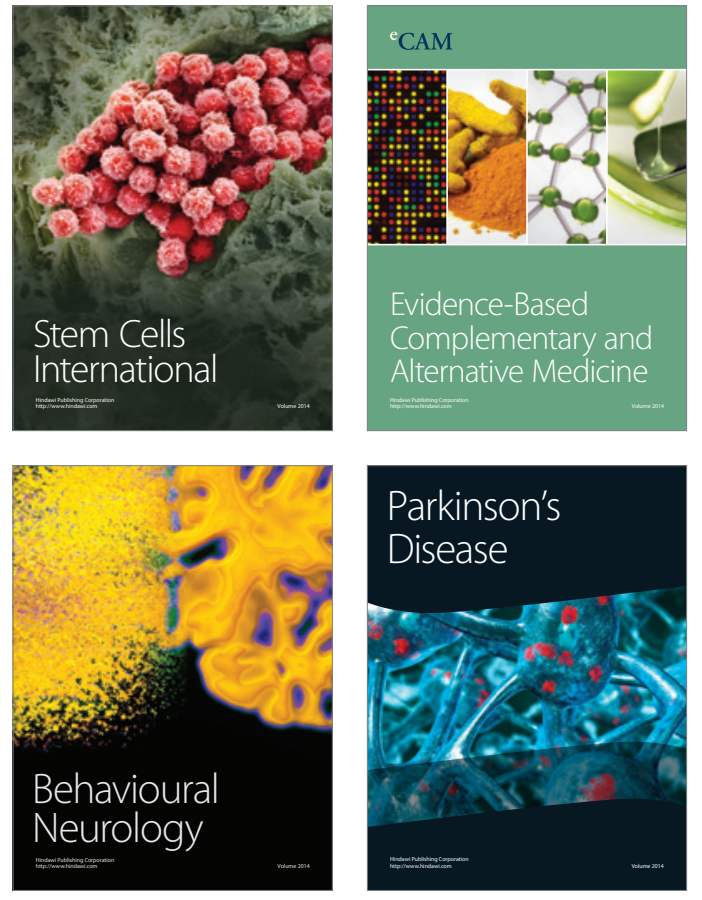
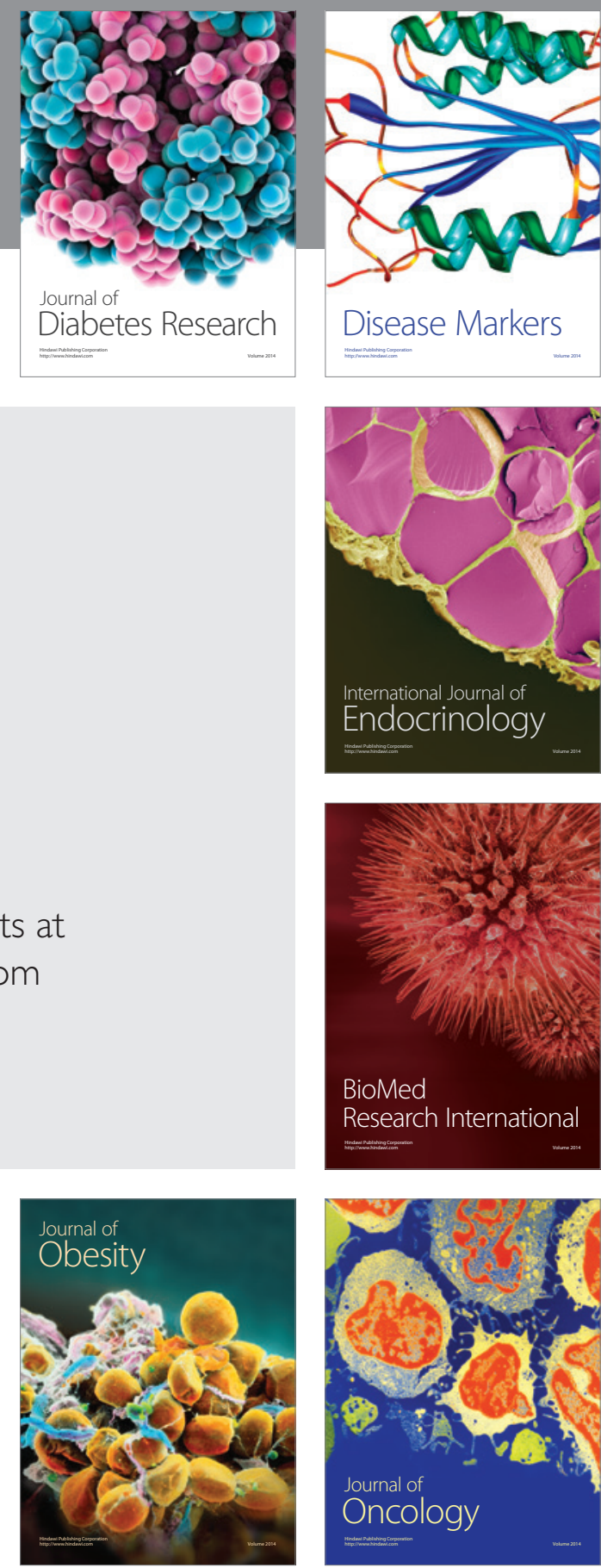

Disease Markers
